\title{
Prohibiting the Pilgrimage: Politics and Fiction in Mālikī Fatwās
}

\author{
Jocelyn Hendrickson \\ University of Alberta \\ jnhendri@ualberta.ca
}

\begin{abstract}
This study inventories and analyzes Mālikī legal opinions (fatwās) discouraging or prohibiting the pilgrimage to Mecca (the hajj) for Muslims in the Islamic West (al-Andalus, North Africa, and West Africa) from the eleventh through nineteenth centuries. This distinctively Mālikī discourse initially may have reflected the risks of long-distance travel from the western periphery to the central Islamic lands. From the twelfth century, most of these texts reflect a ruler's unstated desire to keep his subjects and their resources at home. Jurists produced fatwās that justified in religious legal terms a regional dispensation from, or even prohibition of, the hajj; that masked the political motives for doing so; and that the lay public could grasp readily. The crafting of such complex opinions is explored, including the use of two "fictional" elements: dissemblance, or a discrepancy between the jurists' actual and stated rationales, and the use of imaginative stories as illustrative aids.
\end{abstract}

* I would like to thank the Social Science and Humanities Research Council of Canada, the Killam Research Fund, and the Kule Institute for Advanced Study for their support of this project. Versions of this research were presented on five occasions: the Middle East Studies Association conferences in 2007 and 2010; the Duke-UNC Islamic Studies Graduate Student Conference in 2008; Power Relations and Religious Communities in the Western Mediterranean, a Spain-North Africa Project Symposium, in 2014; and Transnational and Local Networks of Pilgrimage, a workshop hosted by the Department of Religious Studies at Vanderbilt University in 2015. I am deeply grateful to the organizers of these panels and to the participants for their constructive comments. In particular, I would like to thank Abigail Balbale, Camilo GómezRivas, Leor Halevi, Peter Katlis, Yuen-Gen Liang, Jessica Marglin, David Powers, Justin Stearns, Devin Stewart, and the anonymous reviewers for their insightful comments and helpful corrections at various stages of this project. 


\section{Keywords}

Islamic law - Hajj - pilgrimage - al-Andalus - North Africa - Maghrib - West Africa - Ibn Rushd

Muslim jurists working within the Mālikī school of law, dominant in the Islamic West (al-Andalus and North Africa), have been discouraging or prohibiting the pilgrimage to Mecca for Andalusī and Maghribī Muslims since at least the eleventh century. When the Almoravid ruler asked Ibn Rushd the Grandfather (d. 520/1126) if jihād or the hajj is more meritorious for Andalusīs, Ibn Rushd protested that the answer was obvious. The merits of jihād are innumerable, while Andalusīs and Maghribīs are all exempt from the hajj because of their inability to perform it; further, Muslims risking the dangerous journey would incur sin. Ibn al-Munayyir (d. 683/1284) prohibited the pilgrimage for anyone who feared he might delay or mis-pray even one daily prayer on the journey. Ahmad al-Burzulī's (d. 841/1438) voluminous fatwā compilation includes more opinions discouraging the hajj than describing its proper performance. Sultan Muhammad Bello, ruler of the Sokoto caliphate in Nigeria (r. 1815-1837), warned would-be pilgrims not to allow Satan to lure good Muslims onto the road to Mecca.

Local traditions deemphasizing the importance of the hajj, the fifth pillar of Islam, are not unusual. For the vast majority of Muslims, the time and expense, as well as the physical and mental rigors of the pilgrimage, have rendered the hajj impossible or undesirable. While Muslims are not legally obligated to perform the hajj if they are unable to do so, countless alternatives are nonetheless said to replace or surpass the virtues of its performance. A number of Shīi traditions assign far greater merit to the pious visitation (ziyāra) of al-Husayn's shrine in Karbala than to the pilgrimage to Mecca, while for Chistìya Șūfis, pilgrimages to the tombs of the order's five great saints in India are said to be the equivalent of the hajj. ${ }^{1}$ Similar beliefs pertain to visiting a saint's tomb known as the "Ka'ba of Khurāsān" in Turkmenistan, climbing Mount Ciremai in Indonesia, or participating in elaborate hajj-like rituals at the Ethiopian tomb of Shaykh Nūr Husayn. Prominent Șūfīs have proclaimed the heart or the self to be the true $\mathrm{Ka}$ ba, explicitly rejecting the value of the external, physical

1 These examples may be found in $E I^{2}$, s.v. "Ziyāra" (J.W. Meri, et al.). On visiting al-Husayn's tomb, see also Devin Stewart, "Al-Sharīf al-Murtạ̣ā (d. 436/1044)," in Islamic Legal Thought: A Compendium of Muslim Jurists, ed. Oussama Arabi, David Powers, and Susan Spectorsky (Leiden: Brill, 2013), 204. 
pilgrimage to Mecca in favor of the seeker's internal, mystical journey toward annihilation in God. In Rūmī's Mathnawī, for example, a poor old shaykh offers himself to Bāyazīd al-Bisțāmī (d. 261/874) as a more worthy object of circumambulation than the Ka'ba. ${ }^{2}$ Rābī'a al-'Adawiya is said to have dismissed the physical Ka'ba even when it came out to welcome her in the middle of the desert; she sought God alone, not a mere house. ${ }^{3}$

What is surprising about these Mālikì fatwās is that we find subversion of the "orthodox" Islamic requirement to perform the hajj where we might least expect it - in Sunnī legal literature. Traditions that coopt the powerful imagery and rituals of the hajj while supplanting it with alternative forms of pilgrimage are generally labeled "sectarian," "heterodox," or "antinomian." Innumerable sacred sites associated with saints, prophets, prominent scholars, or descendants of Muhammad function as "popular," "local," or "vernacular" pilgrimage destinations, even without an explicit assertion of priority over the hajj. "Official," "orthodox," "normative," or "universal" Islam is predominantly associated with Sunnī legal discourse. Sunnī jurists are the dominant professional elite empowered to define and prescribe those aspects of Islam that claim universal assent, often described as consisting, at a minimum, of the authority of the Qurān and Hadìth and the obligatory nature of the Five Pillars. ${ }^{4}$ In contrast to prescriptive, juridical Islam, popular or vernacular Islam is variously defined as dynamic, emotional, and adaptable; as "practiced and experienced;" as appealing to the masses; or above all, as locally determined and expressed. ${ }^{5}$ Joyce

Jalāl al-Dīn Rūmī, The Masnavi: Book Two, trans. Jawid Mojaddedi (Oxford: Oxford University Press, 2007), 129-31. This passage is excerpted in Norman Calder, Jawid A. Mojaddedi and Andrew Rippin, eds., Classical Islam: A Sourcebook of Religious Literature (New York and London: Routledge, 2003), 342-4.

3 Michael Sells, ed. and trans., Early Islamic Mysticism: Sufi, Qur'an, Míraj, Poetic and Theological Writings (New York: Paulist Press, 1996), 157.

4 Shīī and Șūfì expressions of Islam, of course, also feature official discourses.

5 On "popular" Islam as dynamic, emotional, and adaptable to local contexts, see Jacques Waardenburg, "Official and Popular Religion as a Problem in Islamic Studies," in Official and Popular Religion: Analysis of a Theme for Religious Studies, ed. Pieter Hendrik Vrijhof and Waardenburg (The Hague: Mouton Publishers, 1979), 340-86; on "popular" Islam as "practiced and experienced, rather than being defined and assigned," see Navtej Purewal and Virinder Kalra, "Women's 'Popular' Practices as Critique: Vernacular Religion in Indian and Pakistani Punjab," Women's Studies International Forum, 33 (2010): 384; on "popular" indicating a mass following, see Martin van Bruinessen, "Sufism, 'Popular' Islam and the Encounter with Modernity," in Islam and Modernity: Key Issues and Debates, ed. Muhammad Khalid Masud et al. (Edinburgh: Edinburgh University Press, 2009), 130; on "folk" or "popular" Islam as adapted to local circumstances, see Patrick Gaffney, "Popular Islam," The Annals of the American Academy of Political and Social Science 524 (1992): 38; 
Burkhalter Fleuckiger, for example, defines vernacular Islam as "knowledge and practice particular to a locality," and reminds us that "universal Islam is lived locally."

These Mālikì opinions challenge the familiar dichotomy between the juridical and the local by demonstrating that Sunni legal literature may be a malleable vehicle for the advancement of local interests and identities, even against standard understandings of the Five Pillars, those core components of universal Islam. Muslim jurists, too, live locally, and the knowledge they produce is subject to powerful local and regional pressures. ${ }^{7}$

In this essay, I argue that many of these fatwās reflect a ruler's unstated desire to keep his subjects and their resources at home. The specific reasons for this desire vary according to historical context and are not always apparent from the texts. As the obligation to perform the hajj provides every Muslim with a valid religious imperative (or excuse) to travel abroad, any public policy discouraging or preventing this journey also must be justified in religious legal terms. Thus, rulers solicited (or in one case, drafted) supporting fatwās from authoritative jurists.

This need to justify a political policy in religious terms placed the jurist in a complicated position. Normally, we associate Sunnī jurists' attempts to change public behaviors with their condemnations of widespread practices regarded as reprehensible innovations (bida ${ }^{c}$ ), or of Sūfì or Shi'ī "excesses." Examples involving the coercive power of political authorities include the destruction of shrines in modern Saudi Arabia and the 'Abbāsid execution of Manșūr alHallāj (d. 309/922) for, among other offenses, advising those too poor to perform the hajj to construct a Ka'ba in their own homes. ${ }^{8}$

and on "local" Islam as "a repertoire of various inclusive religious practices that embraces diverse devotional traditions in one specific place," see Afsar Mohammad, The Festival of Pìrs: Popular Islam and Shared Devotion in South India (Oxford: Oxford University Press, 2013), 3 .

6 Joyce Burkhalter Flueckiger, In Amma's Healing Room: Gender and Vernacular Islam in South India (Bloomington: Indiana University Press, 2006), 2.

7 I am not positing the absence of any meaningful divide between universal normative ideas and local practices, or between actions prescribed by elites and those practiced by laypersons. The legal discourse scrutinized here remains the prescriptive preserve of religious elites, often in collaboration with political elites, and thus tells us something very different than would observation of Andalusī and Maghribī Muslims' actual behaviors. The point is that law is not confined to the realm of the universal; it is interpreted and adapted locally, like any other aspect of Islam.

On the trial and execution of al-Hallāj, see Carl Ernst, Words of Ecstasy in Sufism (Albany, N.Y.: SUNY, 1985), 102-10. As noted by one anonymous reviewer, Saudi Arabia and the 
In the case of these pilgrimage fatwās, the relationship between normative Islam and public practice is inverted. Here, the common people's presumed desire to perform the canonical pilgrimage to Mecca is countered by (often state-solicited) legal opinions warning would-be pilgrims not to attempt the journey. This inversion requires the jurist to simultaneously uphold the universal obligation of the hajj while arguing for a regional dispensation from this requirement. Where the ruler has solicited an opinion legitimizing an enforceable ban on the pilgrimage, the jurist must transform that regional dispensation into a prohibition. ${ }^{9}$

I argue that the process of prohibiting a pillar of Islam often requires the jurist to dissemble, that is, to mask the real political concerns informing his formal opinion. ${ }^{10}$ In this essay, I explore the constraints and incentives that render such complex fatwās non-transparent. All legal texts are constructed in accordance with specific parameters that dictate what constitutes a legitimate legal argument or a legally significant category. Thus, we should not assume any argumentative legal text to be a completely straightforward, transparent reflection of the underlying concerns motivating a particular case; these concerns will be obscured to the extent that they do not conform to accepted legal discourse. ${ }^{11}$ Yet many scholars treat legal texts as unadulterated reflections of

'Abbasids of course exercised power in very different ways. I acknowledge that the nature of political power changed considerably over the long centuries considered in this article, and consequently that the precise nature of the relationships between jurists and political authorities changed as well. Unfortunately, it is outside the scope of this article to elaborate on each of these specific relationships. For most of the cases treated here I am asserting simply that the exercise of political power, however constituted at a given moment, impacted decisively the expression of the law.

9 This transformation of legal dispensations into disabilities most often benefits male elites whose self-interest promotes restrictive interpretations of rules for women and minorities. The slave's non-obligation to perform the pilgrimage in classical law, for example, denies slaves the right to travel more so than it "frees" them. The fact that women are not obligated by ritual law to attend Friday congregational prayers in mosques is cited by community leaders in India as adequate justification for prohibiting women's entrance into male-only mosques and for refusing to finance women's mosques.

10 On "dissemblance" as an underexplored modality of juristic discretion involving misrepresentation, see Jocelyn Hendrickson, "Is al-Andalus Different?' Continuity as Contested, Constructed, and Performed in Three Mālikī Fatwās," Islamic Law and Society 20.4 (2013): 400-1.

11 For example, in October 2015 a group of Edmonton residents successfully lobbied the city to order the removal of a months-long yard sale in their neighborhood. The residents all complained that the sale was an obnoxious eyesore, but to solve the problem the city invoked a municipal code that prohibited the establishment of businesses within 
the jurist's thoughts, mining each text for data on his arguments and positions without questioning sufficiently the influence of political power or other contextual factors on the shaping of the written narrative. One scholar, for example, has asserted recently that the most logical approach to interpreting a given jurist's fatwās, even those focused on politically sensitive issues during active warfare is to "view his fatāw $\bar{a}$ as being fundamentally about what he says that they are about."12

In this study, I employ Mālikī fatwās discouraging the hajj as a case study for demonstrating that legal texts are constructed narratives shaped by compelling concerns and contexts that may be stated, unstated, or deliberately masked. ${ }^{13}$ I suggest that all substantial fatwās are subject to a common set of constraints and imperatives, some of them more prominent than others. In the texts under examination here, political and legal constraints are particularly prominent, as is the imperative to craft a message suitable for popular consumption. As a result, this series of texts is characterized by two recurring elements that may be considered "fictional": politically motivated dissemblance, and the use of imaginative stories as illustrative aids. ${ }^{14}$ We will return to these

neighborhood limits. Expressing the problem in terms of a zoning violation led to its effective and timely redress, but obscured the residents' real concerns, which were primarily aesthetic.

Alan Verskin, Islamic Law and the Crisis of the Reconquista: The Debate on the Status of Muslim Communities in Christendom (Leiden: Brill, 2015), 22. In this passage, Verskin rejects the argument that Ahmad al-Wansharīsìs (d. 914/1508) two infamous legal opinions, both of which ostensibly address Iberian Muslims living under non-Muslim rule, may also include a veiled commentary on the Portuguese occupation of North Africa.

Devin Stewart has advanced a similar argument in a pair of articles analyzing a group of sixteenth-century legal treatises on the status of Friday prayer in Twelver Shiite law. While ostensibly concerned purely with a matter of ritual law, the treatises in fact employ oblique references, allusions, and innuendo in order to critique living rivals and compete for the patronage of Safavid Shah Tahmasb. See Stewart, "The First Shaykh al-Islām of the Safavid Capital Qazvin," Journal of the American Oriental Society 116.3 (1996): 387-405; idem, "Polemics and Patronage in Safavid Iran: The Debate on Friday Prayer During the Reign of Shah Tahmasb," Bulletin of the School of Oriental and African Studies 72.3 (2009): $425-57$.

My methodology and use of the term "fiction" are inspired in part by Natalie Zemon Davis, Fiction in the Archives: Pardon Tales and Their Tellers in Sixteenth-Century France (Stanford: Stanford University Press, 1987), 3. In her study of sixteenth-century French letters of remission, or "pardon tales," Zemon Davis found that pardon seekers crafted their tales of past transgressions into compelling narratives, ones that would make sense of their crimes for the appropriate audiences and that would conform to the legally acceptable parameters for remission. She uses "fiction" in the sense of a carefully shaped narrative with a beginning, middle, and end, not in the sense of fabrication. Here I 
shaping factors following a discussion of the individual texts and their historical contexts.

\section{Mālikī Fatwās Discouraging or Prohibiting the Hajj}

To my knowledge, the Mālikī school is the only Sunnī legal school to have developed a tradition of legal opinions prohibiting the pilgrimage to Mecca. ${ }^{15}$ The bulk of this study seeks to establish that tradition by offering a preliminary inventory and analysis of Mālikī legal opinions discouraging or prohibiting the hajj for Muslims in al-Andalus (Islamic Iberia), North Africa (the Maghrib), and West Africa. ${ }^{16}$ The question of why this tradition might have arisen in the Islamic West will be addressed below.

emphasize this same link between the law and crafted narratives, but reserve "fiction" for the manipulation of "truth" and for imaginative stories or myths.

While it would be nearly impossible to demonstrate the non-existence of any other such legal opinions in any other schools at any time, I am aware of no studies that mention isolated legal opinions, much less a centuries-long tradition, treating the hajj as prohibited or sinful, or exempting entire regions from its performance. The Mālikī opinions make no reference to corresponding opinions in other schools, although we would not expect them to do so. As a point of comparison to such comprehensive Mālikì compilations as al-Wansharīis's al-Mi'yāral-Mu'rib, I consulted the pilgrimage section of al-Fatāw $\bar{a}$ al-'Ālamgìrīya, the vast seventeenth-century compendium of Ḥanafì law commissioned by Mughal sultan Awrangzīb 'Ālamgīr (r. 1658-1707) and compiled by over forty Hanafì scholars. The opinions included discuss several aspects of 'ability' and enumerate the usual conditions for individual exemptions from the obligation to perform the pilgrimage (including sickness, lack of transportation, or a woman's lack of an appropriate escort). None of the cited opinions describes conditions under which the pilgrimage would be prohibited or sinful in the eyes of the law, although fear of a ruler who has banned hajj travel is included as a valid reason not to go. By contrast to Mālikī opinions regarding "ability," greater emphasis is placed on the lengths to which Muslims might go in order to meet the condition of "ability." For example, a woman need not marry simply in order to procure a suitable escort; a man need not sell his only home in order to afford the hajj; and a professional jurist need not sell his legal works in order to make the pilgrimage. But an ignoramus in possession of the same legal works must sell them, as should the owners of books on such (lesser) subjects as medicine and astronomy; these works always count toward one's financial "ability," even if used professionally. See Shaykh Nizāam (d. 1089/ 1678), al-Fatāwā al-Hindīya: al-ma'rūfa bi'l-Fatāwā al-'̄lamkīrīya fì madhhab al-imām al-a'zam Abì Ḥanīfa al-Nu'mān, ed. 'Abd al-Lațîf Ḥasan 'Abd al-Raḥmān (Beirut: Dār al-Kutub al-'Ilmīya, 2000), 1: 239-42. 
These opinions center on the question of ability: Muslims are obligated to perform the pilgrimage only on the condition that they are able to do so. Thus, I conducted a thorough search of all the printed and manuscript Mālikī fatwa collections I could locate, looking for opinions that addressed the ability of Maghribī and Andalusī Muslims to perform the pilgrimage. This search yielded eleven complete texts issued by ten jurists between the eleventh and nineteenth centuries. Additional jurists are quoted or paraphrased within these fatwās as having argued that Maghribī or Andalusī Muslims, as a group, do not meet the condition of being able to perform the pilgrimage. While these citations grant us a fuller picture of this centuries-long phenomenon, I focus here only on opinions for which we appear to have the full answer, if not also the original question. ${ }^{17}$ Opinions will be treated in chronological order, but my analysis will focus unevenly on those texts for which the historical context is most discernable and which illustrate most clearly the interplay between regional political pressures and narrative form, including the use of fiction.

\section{$1 \quad$ Al-Lakhmī, nth-century Ifrīqiya}

The first two fatwās were issued by Abū al-Hasan al-Lakhmī (d. 478/1086), a prominent jurist from Qayrawān. ${ }^{18}$ In the first question, al-Lakhmī is asked

cerns Morocco only, I use the more specific term "the Far Maghrib," and likewise I employ "Ifrīqiyā" for the territory roughly corresponding to modern-day Tunisia.

With one exception (Muhammad Bello's treatise), I have restricted my search to fatwās, the legal genre most likely to feature material that is clearly responsive to particular historical circumstances. While a thorough search of all Mālikī legal works is beyond the scope of this project, works in at least two other genres figure strongly in these fatwās: Al-Madhkal by Ibn al-Hājj (d. 737/1336), a work on reprehensible innovations, and Mawāhib al-jalïl li-sharh Mukhtaṣar Khalïl (Gifts from the Glorious for Explaining Khalī's Abridgment) by Ibn al-Ḥaț̣āb (d. 954/1547), a commentary on the Mukhtașar of Khalīl b. Ishāa. Further searches in these genres of legal works likely will yield additional relevant opinions.

18 Abū al-Ḥasan 'Alī b. Muhammad al-Rib'ī al-Lakhmī (d. 478/1085-6) was raised and educated in Qayrawān prior to settling in Sfax. His biographers describe him as the most prominent jurist in Ifrīqiyā in his time, noting that his fame and fatwās spread widely. Al-Lakhmī's major work is al-Tabșīra, a commentary on the Mudawwana. Hamīd Lahmar has published an edition of al-Lakhmī's fatwās, compiled from other published collections: Al-Lakhmī, Fatāwā al-Shaykh Abì al-Hasan al-Lakhmì al-Qayrawānī, ed. Hamīd Laḥmar (Casablanca: Dār Márifa, 2006). On al-Lakhmī, see Ibn Farḥūn, al-Dībāj al-mudhahhab fì ma'rifat a'yān 'ulamā’ al-madhhab, ed. Ma'mūn b. Muhyī al-Dīn al-Jannān (Beirut: Dār al-Kutub al-'Ilmīya, 1996), 298; Muḥammad Makhlūf's Shajarat al-nūr alzakiyya fì țabaqāt al-Mālikīya, ed. 'Abd al-Majīd Khayālī, 2 vols. (Beirut: Dār al-Kutub al-'Ilmīya, 2003), 1: 173; 'Abd al-Raḥmān b. Muhammad al-Dabbāgh (d. 699/1299-1300) and 
about a would-be pilgrim who was planning to travel by sea, because the overland route was too dangerous. ${ }^{19}$ Yet he also feared the sea route. Someone told him that there is no obligation to perform the hajj, given the risks involved. The mustaftì (questioner) asks:

In your opinion, is travelling by sea permitted, despite what is feared from it? In these times, must a man hasten to undertake the hajj, or should he delay because of the brigands along the route? If he delays and dies prior to performing the pilgrimage, is he a sinner, considering that he is prepared, with nothing preventing him [from going] other than fear of the overland route and the risk of travelling by sea? We have been told that one of the early master jurists held that the obligation to perform the pilgrimage has lapsed.

This passage suggests that the dangers of the journey were the primary concern for aspiring pilgrims who were otherwise "prepared," i.e., physically and financially capable of travelling a great distance. The questioner also refers to an established legal debate over whether or not the hajj must be undertaken immediately upon meeting the condition of ability or if it may be delayed. Finally, he notes the circulation of an opinion that this obligation had "lapsed," meaning that as a general rule no one could be considered "able" to perform the pilgrimage, and thus the obligation to do so was not in effect. The fact that this opinion is attributed to one of the Mālikī school's "early" jurists suggests that opinions exempting regional Muslims from the hajj may have circulated a full century prior to al-Lakhmī's fatwā; Mālikīs consider the early period to have ended with Ibn Abī Zayd al-Qayrawānī (d. 386/996). ${ }^{20}$

Al-Lakhmi's answer is brief, stating that the conditions of the route between Alexandria and Mecca are such that no one is obligated to perform the pilgrimage, and no sin is incurred by delaying. He thus proclaims a general non-obligation for Ifriqiyan Muslims to perform the pilgrimage, without addressing the first question regarding the permissibility of travelling by sea regardless of the dangers. Al-Lakhmī is implicitly addressing travel by sea, as ships from Ifrīqiyā

Abū al-Qasim b. Nājī al-Tanūkhī (d. 839/1435-6), Ma'ālim al-īmān fì ma'rifat ahl al-Qayrawān, ed. 'Abd al-Majīd al-Khayālī, 5 vols. in 3 (Beirut: Dār al-Kutub al-'īlmīya, 2005), 2: 200-201 (entry 317).

19 See Appendix A for a full translation and discussion of sources.

20 Mālikīs consider Ibn Abī Zayd to be the school's first "later" jurist. Maryam Muhammad

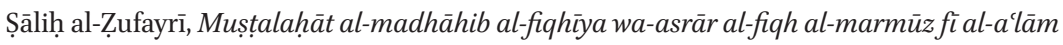
wa'l-kutub wa'l-ārā’ wa'l-tarjīhāt (Beirut: Dār Ibn Ḥazm, 2002), 156. 
ported in Alexandria whereas the overland route reached Cairo directly. He does not address the conditions of overland travel between Ifrīqiyā and Cairo.

In the second question, al-Lakhmī is pressed further on the issue of permissibility. Here the case involves a man who has already set forth on the pilgrimage and is unlikely to complete the journey safely. The questioner asks if such a man will be rewarded for his efforts, or if he will incur sin by putting himself in harm's way. He also wishes to know if the man will be rewarded even if this were not his first hajj. Al-Lakhmì reiterates that the obligation to perform the pilgrimage has lapsed, and states that such a man "will not be free of sin." The implication is that the pilgrim's assumption of an unnecessary and significant risk of harm is sinful, whether he is performing an obligatory or supererogatory pilgrimage.

Al-Lakhmī's fatwās are undated, and the identity of the questioner is not known. ${ }^{21}$ Both questions are framed to apply to any pilgrim, rather than to the specific circumstances of an individual private petitioner. Al-Lakhmì's responses are similarly framed in general terms. As the dangers of the route between Alexandria to Mecca affect all Ifriqiyan Muslims, they are as a class exempt from the hajj and will incur sin if they attempt the journey.

While al-Lakhmī locates the route's dangers in the heart of Fātimid Egypt ("from Alexandria to Mecca"), the overland route from Ifrīqiyā to Cairo would also have posed serious difficulties for pilgrims. In 1049 the Zīrid viceroy of Ifrīqiyā, al-Mu'izz b. Bādīs (r. 1016-1062), declared independence from the Ismaîilī Fāṭimid caliph al-Mustanșir bi'llāh (r. 1036-94), proclaiming allegiance instead to the Sunnī 'Abbāsids. ${ }^{22}$ In retaliation, the Fāṭimid vizier al-Yāzūrī

The questioner may be al-Lakhmī's student al-Māzarī (noted below), or any of his other students engaged in a scholarly discussion of a current dilemma. In his monumental fatwā collection, al-Mi'yār al-Múrib, Ahmad al-Wansharīsī (d. 914/1508) includes a second version of the first question posed to al-Lakhmī. In this version, al-Māzarī (d. $536 / 1141$ ), who acts as the mustafti, directs the question to his other primary teacher (aside from al-Lakhmī), 'Abd al-Ḥamīd Ibn al-Ṣāigh (d. 486/1093). Ibn al-Ṣāigh laments the calamities of their time and states that the end of the world is near, but he does not make any sweeping statements regarding his contemporaries' obligation to perform the hajj; he advises al-Māzarī to wait until the route is safe. This fatwā is included in Aḥmad b. Yahyā al-Wansharīsī, al-Mi'yār al-mu'rib wa'l-jāmi' al-mughrib 'an fatāwì ahl Ifrì̃iyà wa'l-Andalus wa'l-Maghrib, ed. Muḥammad Ḥajjī et al., 13 vols. (Rabat: Wizārat al-Awqāf wa'l-Shu'ūn al-Islāmīya, 1981-83), 1: 435-6. On Ibn al-Ṣāigh, see Ibn Farḥūn, al-Dībāj, 26o; Makhlūf, Shajarat al-nūr, 1: 174; al-Dabbāgh and al-Tanūkhī, Ma'âlim al-īmān, 3: 201-2. While he appears in the Mi'yār as 'Abd al-Ḥamīd al-Ṣāigh, this jurist must be al-Māzarī's teacher Ibn al-Ṣāigh. 
encouraged the Banū Ḥilāl and Banū Sulaym tribes to invade Ifrīqiyā. The Banū Hilāl conquered Qayrawān in 1057 and occupied much of the countryside, forcing the Zīrids to abandon their capitol and reducing their state to a small territory centered in Mahdiya. Pilgrims from such a weak state would have found travel though hostile Hilālian and Fāțimid territory treacherous, a reality that al-Lakhmì's response conveniently elides, thus avoiding any critique of the Zīrid state. For any pilgrims arriving safely in Egypt, al-Lakhmī's description of the situation was apt. Cairo was particularly inhospitable in the 1050s and 106os, when severe famines and internal divisions resulted in starvation and bloodshed, crippling the economy and producing a period of anarchy.

\section{$2 \quad$ Al-Māzarī, nth-12th-century Ifríqiyā}

The third fatwā under consideration was issued by Abū 'Abd Allāh Muhammad al-Māzarī (d. 536/1141), recognized with the honorific title "Imām," or master jurist, for his legal knowledge and formative role in the development of the Mālikī school of law. ${ }^{23}$ A student of al-Lakhmī's, al-Māzarī lived in Zīrid Mahdiya, where he taught, authored approximately a dozen works, and issued hundreds of fatwās. ${ }^{24}$ The first thirty years of al-Māzarì's life coincided with the Norman conquest of Muslim Sicily, completed in 1091. The Zīrids' frequent maritime raids provoked a joint Pisan and Genoese attack on Mahdiya, which was sacked in 1087 and briefly occupied by the invaders. Seven years after alMāzarī's death, Roger II of Sicily conquered the small Zīrid state, bringing this dynasty to an end in 1148 .

Al-Māzarì's fatwā on the obligation to perform the pilgrimage is framed as an opinion he developed either during or, more likely, as a result of an oral debate among al-Lakhmī's circle of peers and students. ${ }^{25}$ As al-Māzarī was

taken from Heinz Halm's recent article on the Fāțimids. See $E I^{3}$, s.v. "Fāțimids" (Heinz Halm); cf. $E I^{2}$, s.v. "Fāțimids" (M. Canard); $E I^{2}$, s.v. "Zīrids" (Amin Tibi).

23 On al-Māzarī, see Ḥasan Ḥusnī 'Abd al-Wahhāb, Kitāb al-'Umr fì al-mușannifāt wa'tmưallifin al-Tūnisìȳn, ed. Muḥammad al-'Arūsī al-Mațwī and Bashīr al-Bakkūsh (Beirut: Dār al-Gharb al-Islāmī, 1990), 1: 696-704; Ibn Farḥūn, al-Dībāj, 374-5; Makhlūf, Shajarat al-nūr, 1: 186-8; Khayr al-Dīn al-Ziriklī al-A'ām: qāmūs tarājim li-ashhar al-rijāl wa'l-nisā̄ min al-'Arab wa'l-musta'ribìn wa'l-mustashriqinn, 14th ed., 8 vols. (Beirut: Dār al-'Ilm li'lMalāyīn, 1999), 6: 277.

24 Al-Ṭāhir al-Ma'mūrī has compiled and edited al-Māzarī's fatwās: Fatāwā al-Māzarī, ed. al-Ṭāhir al-Ma'mūrī (Tunis: al-Dār al-Tūnisīya li'l-Nashr, 1994). Hady Roger Idris draws extensively upon al-Māzarī's fatwās in his history of the Zīrid state, La Berbérie Orientale sous les Zïrìds: $X^{e}-X I I^{e}$ siècles, 2 vols. (Paris: Adrien-Maisonneuve, 1962).

25 Norman Calder notes that many of the fatwās preserved in compilations must have arisen during oral debates, only to be polished later. Calder, Islamic Jurisprudence in the Classical 
about twenty-four years old when al-Lakhmì died in 1085 or 1086, this discussion would have taken place quite early in his career. The timeframe for his undated fatwā is thus similar to the early 1080s window during which al-Māzarī must have issued his fatwā prohibiting travel to Christian Sicily for trade. ${ }^{26}$ In the trade fatwā, al-Māzarī offers more detail regarding the heated scholarly debate to which he contributed his own position. The Zīrid sultan had convened a discussion among the region's scholars on the permissibility of travel to Sicily, presumably in order to justify or inform his public policy on the matter. This hajj debate over the applicability of the obligation to perform the pilgrimage appears to have arisen within the group of legal scholars and students who gathered for regular sessions led by al-Lakhmī, likely in al-Mahdìya's congregational mosque. Nonetheless, the sultan may well have taken a similar interest in the outcome of the debate.

In his fatwā, al-Māzarī makes clear that he considers Ifriqiyan Muslims exempt from the obligatory hajj, but he also exhibits a concern to emphasize the contingent nature of this exemption. The question asks for his opinion regarding the idea that "the obligation to perform the pilgrimage is in abeyance in this age."27 Al-Māzarîs immediate response, "The answer to this question is obvious," suggests that he is assenting to a position of non-obligation that must have been commonly held at the time. Yet Al-Māzarī resists making such an explicit and sweeping statement and discourages scholars from making loose generalizations:

The answer to this question is obvious. A knowledgeable scholar must not generalize about this [matter]. It is obvious that the obligation to perform the pilgrimage does not lapse when the [necessary] means are found, and [the pilgrim] does not fear for himself or for his property, and does not fear that he will be led astray in his religion, or that he will commit prohibited acts, or abandon [his] prayers or other obligations.

Al-Māzarī thus opens by resisting too ready a declaration of the hajj's nonapplicability, and by framing the obligation to perform the pilgrimage in active terms: this obligation is presumed to be in effect, provided that certain conditions are met. Yet this daunting list of conditions makes clear that al-Māzarī is not suggesting that his fellow Ifriqiyans are prepared to perform the hajj. Instead, he counters flippant dismissals of the hajj's obligatory status

Era, ed. Colin Imber (Cambridge: Cambridge University Press, 2010), 132 and 139.

26 On this trade fatwā, see Hendrickson, "Is al-Andalus Different?", esp. 377-8 (for the date).

$27 \quad$ See Appendix B for a full translation and discussion of sources. 
by specifying the problems that justify exemption. Al-Māzarī expands upon each of these conditions:

If he fears that he will perish, or that he will attain this [goal of fulfilling the pilgrimage] only by giving much of his money to oppressors along the route, and this loss will reduce him to poverty or cause him severe hardship, then, in this case, the obligation to perform the pilgrimage lapses, according to what our fellow [Mālikī jurists] have stipulated.

Likewise, if he begins to neglect his prayers, by [performing] them outside of their appointed times, or by performing a different [prayer] during a [given prayer's] time, and only pilgrimage travel has placed him in this situation, then this travel is not permissible, and the obligation to perform the pilgrimage has lapsed for him.

If [the problem] is only that he will see and hear prohibited acts, this [case] encompasses a wide range [of specific situations], and he [viz., the mufti $]$ must discern the specific nature of the prohibited act as well as the method for escaping it. Discussion of this [matter] in general terms is inappropriate, because that does not allow for a detailed exposition.

This first paragraph reflects a standard Mālikì definition of the "ability" to perform the pilgrimage: the capacity to arrive in Mecca "without great hardship, and with security of person and property." ${ }^{28} \mathrm{Al}$-Māzarī suggests that in his time unnamed "oppressors" who were extracting fees from pilgrims presented a serious obstacle to completing the hajj journey with security of property.

The second paragraph substantially raises the bar for "ability" by introducing an expectation that pilgrims' five daily prayers not be delayed or confused during the journey. While al-Māzarīs position may accommodate the traveller's usual dispensation for shortening prayers while on the road, he does not appear to sanction combining the noon and mid-afternoon prayers, or the sunset and evening prayers, as we might expect. Further, he escalates the consequences of not meeting this condition: a would-be pilgrim likely to neglect prayers is not only exempt from the hajj, but also prohibited from attempting the journey. Despite advocating such a high standard for the very permissibility of undertaking the hajj, al-Māzarī returns, in the last paragraph, to the language of careful individual assessment.

28 This is the concise definition of 'ability' that would later appear as essential Mālikī doctrine in the Mukhtaṣar of Khalì b. Ishāq al-Jundī (d. 776/1374), the most influential Mālikī textbook. This definition is cited in the question component of 'Abd al-Hādī al-Ṣiqillī's fatwā, in Appendix D. 
Al-Māzarī continues with a retrospective account of the debate in alLakhmī's study circle. A long, intense disagreement among attendees as to whether or not the obligation to perform the pilgrimage had lapsed appears to have been defused by the interjection of a preacher at the back of the gathered crowd. The man recited two verses of poetry, adapting them to make the point that those piously devoted to performing the pilgrimage will attempt to do so regardless of the obstacles, with little concern for personal loss or injury. AlMāzarī reports that al-Lakhmī approved of the man's remark "from the viewpoint of the Șufì path rather from that of the law," but then he, al-Māzarī, concludes by reiterating, "the correct position on this matter is the one we have previously presented."

This retrospective narrative provides an alternative framework within which the pilgrimage could be permitted despite its questionable legality or validity in the strict view of the law (as interpreted by these jurists). Yet this accommodation of the desire to perform the hajj is restricted to Șufis. AlMāzarì's final line returns to the reality of the average Muslim, as though this exchange between al-Lakhmī and the preacher were a mere fantasy employed to avoid undermining too forcefully the canonical nature of the pilgrimage or the validity of pious longings for its fulfillment.

Al-Wansharīsì opens his chapter on the hajj in the Míyār with a short fatwā by "Judge Abū al-Ḥasan Sīdī 'Ali b. Maḥsūd," whom I have not been able to locate in any biographical dictionaries. In response to a question regarding those who perform the pilgrimage in his day, he states:

They risk their lives, but if they delay, they are excused. Abū Mūsā đ̄sā b. Manās [d. 395/100o] ${ }^{29}$ stated: "If a man takes an oath [to perform the pilgrimage] on foot, it is not permitted for him to set forth. [This is because] the departure of anyone who sets forth today toward Mecca is an act of disobedience and he will not be rewarded. People must delay until God opens [a path]. ${ }^{30}$

Ibn Maḥsūd's fatwā may have been written before or after those of al-Lakhmī and al-Māzarī. I have placed his opinion here as an approximation. Both Ibn Manās and Ibn Mahṣud, by virtue of citing him, share al-Lakhmìs principal

\footnotetext{
29 Al-Dabbāgh and Ibn Nājì, Ma ālim al-'imānn, 3: 130.

$30 \quad$ Al-Wansharīsī, al-Mi'yār $r, 1: 43^{2}$.
} 
concerns regarding the safety of the route, but are far more forceful in prohibiting the journey and ascribing sin to those who attempt it.

\section{Ibn Rushd al-Jadd, 12th-century al-Andalus and the Far Maghrib}

Whereas al-Māzarī's fatwā prioritizes daily prayers over the hajj, Abū al-Walīd Muhammad Ibn Rushd al-Jadd (d. 520/1126) introduces a different hierarchy of religious obligations. ${ }^{31}$ The Almoravid commander 'Alī b. Yūsuf b. Tāshufìn (r. 1108-1142) asked Ibn Rushd, who would have been chief judge of Córdoba at the time, whether the pilgrimage or jih $\bar{a} d$ was of greater merit for the people of al-Andalus. ${ }^{32}$ An addendum to this initial question, also posed by 'Alì b. Yūsuf and dated 515/1121, asked if the same answer applies to Muslims of the Far Maghrib.

This two-part text is the first opinion in this series of fatwās explicitly requested by a ruler, with clear implications for state security. The Almoravids, a Sanhāja Berber dynasty based in Marrakesh, had first entered al-Andalus in 1086 when the Tâaifa kingdoms requested military aid against Alfonso VI of Léon and Castile. Rather than providing aid, the Almoravids seized control of much of the territory formerly governed by these Muslim kingdoms, but were unable to halt the expansion of the Christian kingdoms. ${ }^{33}$ The former Tầ'ifa of Saragossa fell in 1118 to the Kingdom of Aragón, and by 1120, the Almoravid dynasty faced internal rebellions as well as multiple external pressures in Iberia.

While the follow-up question in 1121 may refer to jihād in al-Andalus, the timing suggests a response to Muhammad b. Tūmart's (d. 524/1130) vocal

$31 \quad$ See Appendix C for a full translation of the fatwa and discussion of sources. Ibn Rushd was one of the most prominent Mālikī jurists. "Al-Jadd," meaning "the Grandfather," distinguishes him from his grandson (Ibn Rushd "al-Ḥafid"), the philosopher known as Averroes, who bears the same Arabic name. On Ibn Rushd al-Jadd, see Delfina Serrano Ruano, "Ibn Rushd al-Jadd (d. 520/1126)," in Arabi et al., Islamic Legal Thought, 295-322.

Ibn Rushd al-Jadd served as chief judge of Córdoba from 511/1117 to 515/1121. As the followup question from 'Alī b. Yūsuf is dated 515/1121 or 1122 (see below), the original question likely was asked shortly prior, during Ibn Rushd's tenure as judge. The ruler appears to have posed the same question, with similar results, to Ibn Hamdīn (d. 521/1127), who served as chief judge of Córdoba both before and after Ibn Rushd. See Appendix B for a reference to Ibn Ḥamdīn's opinion.

33 The Tâàifa or "party" states were small Muslim successor states to the Umayyad Caliphate of Córdoba after its disintegration in the early eleventh century. The fall of Toledo to Alfonso VI in 1085, considered the first major, permanent conquest in the Christian "Reconquest" of Iberia, prompted the call for Almoravid aid. 
critique of the Almoravid regime's heresy and corruption. In 1121, Ibn Tumart declared himself the Mahdī or divinely guided redeemer. Over the next few years his followers would establish an Almohad political and military center in Tinmal devoted to the overthrow of the Almoravids, an objective they achieved in 1147 with the conquest of Marrakesh. 'Alī b. Yūsuf's two-part question thus represents a moment of transition for the Almoravids, as their armies went from defending one front in Iberia to fighting two distinct campaigns at the northern and southern edges of their empire.

'Alī b. Yūsuf's initial question reads as follows: "Concerning those Andalusīs in our time who have not performed the pilgrimage: Is hajj more meritorious for them or jihād? What about [those who] have completed the obligatory pilgrimage? Go over your thoughts on this matter for us." While the question seems straightforward, it is worth noting what 'Alī b. Yūsuf is not asking, at least not explicitly: May current soldiers and military elites be denied a leave for performance of the hajj? May would-be pilgrims instead be drafted into the army, given that hajj and jihād require the same physical stamina? Should pilgrims insistent on departing be suspected of ulterior motives - defection or spying - in a time of war? Or should they be prevented from travelling in order to guard against their capture? As it is formulated, the question purports to be genuinely concerned with the ability of Andalusis to stand before God on Judgment Day, having made the life choices that will assure them the best possible fate after Resurrection.

Unless we accept that that 'Alī b. Yūsuf posed this question to ease the consciences of men wrestling with a genuine choice between hajj and jihäd, the text obscures the actual motive for, and implications of, this istift $\vec{a}$ (request for a fatw $\bar{a}$ ). While the vested interest of the ruler in Ibn Rushd's response will not have been far from the minds of readers, the text nonetheless avoids disclosing or seeking explicit sanction for the fatwä's policy implications. These will be addressed further below, following a summary of the response.

In Ibn Rushd's initial response, he reviews three scenarios, moving from what he presents as the most obvious to least obvious cases. The first case applies to all Andalusīs in his time:

The obligation to perform the pilgrimage has lapsed in our times for Andalusis because of [their] lack of ability - which God has made a condition of the obligation - because "ability" means the capacity to arrive with security of person and property, and this [capacity] is nonexistent in our age.

Once the obligation to perform the pilgrimage has lapsed for this reason, it becomes supererogatory, [and] reprehensible because it is a 
hazardous undertaking. ${ }^{34}$ It is therefore clear from what we have mentioned that jihād - the merits of which are innumerable in the Qur'ān, in well-attested prophetic traditions, and in reports concerning the Companions - is of greater merit than [hajj]. This is too obvious to require a question.

Like al-Lakhmī and al-Māzarī, Ibn Rushd treats all Muslims in his geographical region as a unified legal class with regards to their "ability" to perform the pilgrimage. His answer is forceful and succinct: No Andalusī may claim an individual capacity to perform the pilgrimage, as that capacity is nonexistent; thus no one is under an obligation to perform the pilgrimage, and anyone doing so exposes himself to needless risk, thus incurring sin. While Ibn Rushd does not go as far as al-Māzarī in opining that the pilgrimage is impermissible for those who will compromise their prayers, he classifies it as a reprehensible action. By qualifying any pilgrimage performed under these conditions as "supererogatory," he denies any would-be pilgrim the merit of performing the obligatory pilgrimage. ${ }^{35}$

Without claiming that jihād is obligatory for Andalusīs, Ibn Rushd offers two compelling arguments in its favor: Waging jih $\bar{a} d$ is of boundless merit, and that merit is assured by the certainty of knowledge that only clear revelatory texts may provide. Compared to a reprehensible attempt to perform a pilgrimage that would not even count as the obligatory hajj, the superiority of jihäd for any capable Andalusî is too obvious, he states, to even ask about.

34 This hazardous undertaking may refer to the first portion of Qurān 2:195: "Spend your wealth for the cause of Allah, and be not cast by your own hands to ruin" (M. Pickthall translation). A general prohibition on risk-taking informs many areas of law, most notably the prohibition on usury.Jiha $\bar{d}$, of course, involves danger and risks as well, but ones that soldiers are expected to assume on behalf of the community. Jurists discussed limits to the degree of risk soldiers may undertake by setting a maximum number of enemies that a Muslim army of a given size should combat. For a translated excerpt treating this point from Ibn Rushd al-Ḥafìd's ("the Grandson," or Averroes, d. 595/1198) Bidāyat al-Mujtahid, a work of comparative law, see Rudolph Peters, Jihad in Classical and Modern Islam, and ed. (Princeton: Markus Weiner, 2005), 38.

'Ability' as a condition of obligation means that the pilgrimage is not obligatory for someone who is unable to perform it. As a condition of validity, it would mean that if a pilgrim is considered unable to perform the pilgrimage, but nonetheless does so, his pilgrimage is invalid for the purpose of fulfilling the once-in-a-lifetime obligation. By classifying an Andalusì's pilgrimage as supererogatory, Ibn Rushd appears to adopt the position that ability is a condition of both obligation and validity. 
Ibn Rushd then entertains two scenarios for which he considers it reasonable to request clarification, even though he has already implied that he considers them both to be purely theoretical. Supposing the route to Mecca was safe, would the hajj or jihād be preferable for Andalusiss? Ibn Rushd dispatches quickly the case of someone who has already performed the obligatory pilgrimage:Jihād remains of greater merit than an additional, supererogatory pilgrimage.

The case of someone who has never performed the hajj is more complicated, requiring Ibn Rushd to review a point of law on which jurists recognized legitimate disagreement. Once an individual has met the condition of ability, does the hajj become an obligation that must be met "immediately" - that is, in the first possible hajj season, often the following year - or might its performance be delayed without sin? Ibn Rushd suggests that, depending on a given jurist's position on this contested matter, the hajj may or may not be considered an urgent priority for the able pilgrim. He then introduces a further consideration that restricts the exercise of this individual discretion: Has the collective obligation to wage jihād been satisfied? ${ }^{36}$ This scope for juristic discretion pertains only if a critical mass of individuals is waging jiha $\bar{d}$, thereby relieving their compatriots of the obligation to do so. If this is not the case, ${ }^{37}$ only one position is accepted: Jiha $\bar{d}$ is more meritorious than the hajj. This univocality follows from the existence of a validly derived opinion in the school according to which the hajj may be delayed. This opinion allowing delay must be adopted in the face of a strong individual obligation to wage jih $\bar{a} d$, as a clear way to reconcile both obligations.

In the addendum in which he responds to 'Alī b. Yūsuf's query regarding Muslims of the Far Maghrib, Ibn Rushd concisely reiterates the same cases and opinions. Only one new consideration is addressed: With regard to those waging jihād, for how long may they defer the pilgrimage? Ibn Rushd indicates that when a person fears that any further delay will result in his failure to fulfill the pilgrimage in his lifetime, the hajj becomes an immediate obligation. While this concession might appear to provide a real scope of choice for soldiers who risk their lives on a regular basis, Ibn Rushd then cites a hadith according to

36 Collective obligations are met by a limited number of people, on behalf of the whole community; they are incumbent upon each individual only until a sufficient number of people have met the obligation on their behalf. Individual obligations apply to all legally responsible Muslims.

Jihād is an individual obligation weighing on all capable Muslims under two circumstances: Either the collective obligation has not yet been met by a sufficient number of fighters or Muslim territory is attacked, triggering a jihād in its defense. 
which Muhammad defines the average Muslim's lifespan as between sixty and seventy years. The implication is that only a sixty-year-old soldier could claim that the hajj had become a more pressing obligation than jihäd.

I have elaborated on this fatwa for several reasons. Ibn Rushd's opinion proved pivotal within Mālikī discourse, becoming a primary authoritative precedent for later jurists. The opinion is particularly visible and compelling because it features a ruler consulting one of the most prominent jurists in his realm on a matter of vital importance to both the legitimacy and continued territorial integrity of the Almoravid empire - the successful prosecution of jihâd. The identity of the mustafti (questioner) and the subject matter of the fatwa make clear that legal literature is being used to advance regional political interests over universal ritual obligations. The opinion affirms in sweeping terms the absolute priority of jihäd over hajj for all Andalusīs and Maghribīs. While fatwās are technically the non-binding advice of an individual jurist, when such "advice" is communicated to a ruler, it provides religious sanction for the use of the state's coercive power to enforce policy.

But what policy? The clear political import of the fatwa does not render transparent the practical motivations or specific implications of the text. Ostensibly, the fatwa is concerned only with the souls of individual Muslims, and, on the surface, it has nothing to do with 'Alī b. Yūsuf. While it is obvious that the Almoravids (and their soldiers) would benefit from religious discourse praising the merits of jiha $\bar{d}$, we can only speculate on the significance of the fatwa $\bar{a}$ s most provocative implication: that the hajj represents a threat to state security. 'Alī b. Yūsuf did not request a treatise on the unsurpassed virtues of the jihâd, nor even an opinion proclaiming jihād to have become an individual obligation. Instead, he seems to have requested an opinion that would provide religious legitimacy for a policy denying any and all of his subjects the "right" to travel abroad to perform the pilgrimage.

Ibn Rushd's two-part opinion provides comprehensive justification for such a policy. He makes short work of showing that all Andalusī or Maghribī Muslims are exempt from performing the pilgrimage and will incur sin by attempting the journey. He builds carefully from this groundwork, ending with the argument that is most difficult to prove, but presumably of greatest strategic value for his patron and ruler: Even when the roads are safe, and a man is otherwise perfectly capable of performing the pilgrimage, and even when that man has already performed jihād, thus earning that greater merit, continued service in jihäd remains more important than the hajj, until and unless that man is at least sixty years old and fears death. This finále suggests that 'Alī b. Yüsuf wanted to prevent soldiers as well as the political and military elite in both al-Andalūs and the Maghrib from deliberately leaving service on the 
pretense of performing the hajj, and to prevent their strategic knowledge or skills from inadvertently falling into the wrong hands if they did leave.

The famous polymath Ibn Khaldūn (d. 808/1406), writing nearly three centuries later, offers valuable insight into 'Alī b. Yūsuf's motivations. In discussing the dangers and unpleasantries of government service, Ibn Khaldūn remarks:

It is difficult and impossible to escape (from official life) after having once been in it ... If the person who intends to escape is one of the ruler's inner circle and entourage or one of the dignitaries in his dynasty, he rarely is given the opportunity to do so. The reason is, in the first place, that rulers consider their people and entourage, and, indeed, all their subjects as slaves familiar with their thoughts and sentiments. Therefore, they are not disposed to loosen the bonds of servitude binding the person (who may have the desire to escape). They want to avoid the chance that someone (outside) might come to know (their secrets) and their circumstances (through that person), and they are averse to letting him become the servant of others.

The Spanish Umayyads thus prevented their people from going abroad to fulfill the duty of the pilgrimage. They were afraid they might fall into the hands of the 'Abbāsids. During all their days, none of their people made the pilgrimage. The pilgrimage was (again) permitted to (Spaniards) who belonged to the (various) dynasties in Spain, only after the Umayyad rule had come to an end and (Spain) had reverted to control of the [Ṭāifa kings]. ${ }^{38}$

In this passage, Ibn Khaldūn addresses the strategic importance of preventing political elites with valuable talents and sensitive information from "escaping" to rival courts or being taken captive. Ibn Khaldūn himself used the pilgrimage as a pretext for escaping the service of Hafșid ruler 'Abu al-'Abbas in 1382, defecting to the more powerful Mamlūk court in Egypt. ${ }^{39}$ The Umayyad ban on pilgrimage for "their people" likely means that political elites were consistently denied permission to leave, not that all Andalusīs were prevented from

38 Note that the translator's use of "Spanish," "Spain" and "Spaniards," instead of references to al-Andalus or Iberia, is anachronistic. Ibn Khaldūn, The Muqaddimah: An Introduction to History, trans. Franz Rosenthal, 2nd ed., 3 vols. (London: Routledge, 1967), 2: 99-100. Allen Fromherz discusses this passage in Ibn Khaldun: Life and Times (Edinburgh University Press, 2010), 91-2.

39 Fromherz, Ibn Khaldun, 91, 99. Note that requests to perform the hajj may be as disingenuous as 'Alī b. Yūsuf's purported concern for his subjects' souls. 
performing the hajj. In comparison with this Umayyad policy, Ibn Rushd's fatwā for 'Alī b. Yūsuf is of broader scope, covering all Andalusīs and Maghribīs but targeting, in particular, all military elites and soldiers associated with jiha $\bar{d}{ }^{40}$ This broader audience explains the need for a fatwa suitable for dissemination, one that foregrounded the ruler's concern for the wellbeing of his subjects and that contained a straightforward, unambiguous message.

It is also possible that 'Alī b. Yūsuf was as concerned to assert the superiority of al-Andalus over the Hijāz as he was to prevent pilgrimages. If jihād is more meritorious than the hajj, it follows that those lands in which active jihäd is being carried out - most notably al-Andalus and the Maghrib - are more important or even more "central" than Mecca, the locus of the hajj. Read this way, the fatwa $\bar{a}$ fosters a regional pride among Andalusīs and Maghribīs and enhances the value of loyalty to the Almoravid regime, whose legitimacy and religiopolitical centrality is bolstered by their active defense of dār al-Islām on the Christian-Muslim frontier. ${ }^{41}$

Ibn Rushd's fatwā exhibits a tension between two approaches to jihād. On the one hand, the text assumes an audience for which jih $\bar{a} d$ is a popular and fundamental religious value; otherwise, its glorification and execution would not bestow legitimacy on the regime or prove compelling for jurists and readers. On the other hand, as a prominent jurist's legal counsel to a ruler with coercive power over his subjects, the fatwa manipulates this popular value to place particular individuals at the disposal of their ruler for military pursuits. This manipulation involves the suppression of another religious duty - one that grants the individual religious merit and locates the focal point of religious devotion in the East - in favor of one that subsumes the individual in a collective pursuit and focuses religious devotion on the religio-political aspirations of a regional power.

The tension in Ibn Rushd's first fatwā is underscored by a second fatwa that al-Burzulī attributes to him. We do not appear to have the complete question, which presents Ibn Rushd with the consensus of his peers that Andalusīs are

40 Countless other professions may be crucial to the war effort, but only people of some means and portable skills or knowledge constitute a real flight risk.

41 Justin Stearns notes a similar connection between praise of $j i h \bar{a} d$ and praise of al-Andalus as a land of jihād in Maghribī historian al-Maqqarī’s (d. 1041/1631) Nafh al-Tīb. Al-Maqqarī records a letter in which the Granadan vizier Ibn al-Khațīb (d. 776/1374) advises his master about the superiority of jihād over the hajj. In commenting on this letter, al-Maqqarī praises al-Andalus: "Know that if there was for al-Andalus no virtue save in its being a field for the excellent to carry out jihād, it would be enough." As quoted in Stearns, "Representing and Remembering al-Andalus: Some Historical Considerations Regarding the End of Time and the Making of Nostalgia," Medieval Encounters 15: 2-4 (2009): 364 . 
exempt from the obligation to perform the hajj, and then must challenge him to produce a proof-text specifically mentioning al-Andalus as exceptional in this regard. Ibn Rushd responds by asserting that "what is obligatory is a conviction that Andalusiss are like everyone else with regard to the obligation to perform the pilgrimage." ${ }^{\prime 2} \mathrm{He}$ adds that no proof text indicates that the hajj is in abeyance specifically for Andalusīs. Much like al-Māzarī, he makes this exemption contingent upon particular circumstances that happen to render all Andalusiss incapable of performing the pilgrimage. This second fatwa reveals a discomfort with the language and message of the first, which so readily and forcefully redirected the aspirations of Andalusiss (and Maghribis) toward jiha $\bar{d}$, not only by exempting them from the hajj, but also by condemning as sinful any attempt to perform it. The source of this discomfort is twofold: The imperative to suppress a religious obligation, the hajj, under the political constraints of issuing the first fatwa ; and the need to reach a wide audience by crafting a message less encumbered by the nuances of legal argument.

\section{$5 \quad$ Abū al-Qāsim al-Burzulī, 15th-century Ifríqiyā}

Trained in Qayrawān, Abū al-Qāsim al-Burzulī (d. 841/1438) settled in Tunis and gained a reputation as the most knowledgeable jurist of his day. ${ }^{43}$ In 1408 , he accepted an appointment as the muftī and imām of al-Zaytūna mosque in Tunis, the highest such post in Ḥafșid Ifrīqiyā. In addition to teaching, preaching, and issuing fatwās, he compiled thousands of North African and Andalusī fatwās into his Jāmi masāil al-aḥkām, one of the largest collections of Mālikī fatwās (seven volumes in print). This compilation, which is one of our primary sources for the opinions treated thus far, served as one of al-Wansharisis's major resources for his much later, and larger collection, al-Mi'yär al-Mu'rib.

Al-Burzuli figures here both as a compiler and a mufti. The short chapter on hajj in Jāmi 'masāil al-ahkām, which opens with Ibn Rushd's fatwās on pilgrimage and jiha $\bar{d}$, is devoted primarily to opinions regarding the non-performance of the pilgrimage. ${ }^{44}$ These include the opinions of al-Lakhmī and al-Māzarī, above, as well as fatwās and other legal commentary on such issues as delaying the pilgrimage, obtaining parental permission, being "unable" to perform the pilgrimage because of a lack of water along the route, the difficulties of ob-

42 Granadan jurist al-Shātịīī also issued a fatwā in which he denies the legal exceptionalism of al-Andalus. See Hendrickson, "'Is al-Andalus Different?', 382-94.

43 On al-Burzulī, see: Abū al-Qāsim al-Burzulī (d. 841/1438), Fatāwā al-Burzulī:Jāmi‘ masā̉il al-ạ̣kām li-mā nazala min al-qaụāyā bi'l-muftīn wa'l-hukkām, ed. Muḥammad al-Ḥabīb al-Hīlah, 7 vols. (Beirut: Dār al-Gharb al-Islāmī, 2002), 1: 5-46.

Al-Burzulī, Jāmic masāil al-ahkām, 1: 584-604. 
taining proper funds by which to finance the hajj, and the ritual and legal implications of having to abandon a hajj attempt enroute after being surrounded or imprisoned by enemies. The chapter closes as it began, with a fatwa by Ibn Rushd emphasizing the inferiority of the hajj to jihād. In this closing fatwa $\bar{a}$, Ibn Rushd is asked about two hadith reports, one stating, "Friday prayer is the hajj of the poor," and the other, "Hajj is the jihäd of the weak." 45 He declares both to be inauthentic, but explains them nonetheless: Those who are too poor to be "able" to perform the pilgrimage must turn to Friday prayers for the cleansing of their sins, and those who are too weak to engage in jihäd, yet are able to perform the pilgrimage, must do so. The effect of the chapter as a whole is to render exemption from the hajj the default status even for healthy, financially secure Muslims anywhere in North Africa or Iberia. The further, devastating implication of the opening and closing fatwās by Ibn Rushd is to cast the hajj as either a sinful shirking of a higher duty or a spiritual scrap left to the incapable.

Curiously, within this chapter al-Burzuli's own opinions vacillate between cautionary and permissive approaches to the pilgrimage. ${ }^{46}$ Of particular interest here is his commentary following al-Lakhmī's two fatwās regarding the ability to perform the pilgrimage. ${ }^{47}$ The fact that al-Burzuli mentions his own completed pilgrimage indicates that this undated commentary must have been composed between 1398, when he returned from Mecca, and 1438, the year of his death. This period coincides with the reign of the Hafșid ruler Abū Fāris (r. 1394-1434).

Al-Burzulī's initial commentary, which is critical of the hajj, begins with alMāzarī's opinion that a would-be pilgrim who suspects himself incapable of maintaining all regular prayers during the journey should not attempt the pilgrimage. Al-Burzuli then introduces two new elements into the discourse: the appeal to eyewitness testimony as evidence regarding the behavior of actual pilgrims, and an explicit focus on lay Muslims (al-'awwām). He also returns to the narrative storytelling first encountered in al-Māzarìs retrospective.

These three elements combine to illustrate the various ways in which commoners invalidate their own pilgrimages with their false intentions, sinful behaviors, neglect of prayer, and ignorance of proper ritual performance. Al-Burzulī confirms that both he and his teacher, Abū Muhammad al-Shabībī

\footnotetext{
45 Al-Burzulī, Jāmi' masāil al-ạ̣kām, 1: 604.

46 While al-Burzulī's contributions are not technically fatwās (the questions were not posed to him directly), they are included here because they provide his unabridged legal opinions, as a leading muftì and legal scholar, on the fatwās issued by others. 
(d. 782/1380), observed during their own pilgrimages that a majority of the laypeople around them exhibited such deficiencies. The image of sin-ridden, misguided pilgrimages is conveyed most forcefully by a story purportedly told by a Maghribī student to al-Shabībī in al-Burzulīs presence:

The demonic beings of the East and of the West argued over which of them is greater in leading [men] astray. The demonic beings of the East said to the demonic beings of the West: "We are stronger than you, because we incite men to acts of disobedience and the violation of prohibitions at the sacred sites of the prophets - may prayers and peace be upon them." Then the demonic beings of the West said: "We are more powerful than you in leading [men] astray, because we find a man who is with his family and children, and he is performing the required prayers, almsgiving, and other duties, and he is at ease, and his angels are likewise [at ease] with him because of the paucity of misdeeds [to be recorded against him]. But when a poet's recitation inspires longing for the land of the Hijāz, we urge him on with a knife and prompt him to set forth, and then he sets forth. Then from the day of his departure, we prompt him to abandon his required duties and to commit prohibited acts. From the day of his departure until the day of his return to his family, he suffers loss in his person, his wealth, and his religion, in the eastern and western parts of the earth." Therefore the demonic beings of the East conceded [to the demonic beings of the West] that they held the [greater] power to lead [men] astray. 48

Here, the desire to perform the pilgrimage is a poetry-induced vulnerability seized upon by demonic beings, under whose coercive influence an otherwise good man is lured onto the road to ruin. Rather than drawing closer to God, demonstrating his piety, or having his sins washed away, the pilgrim takes an extended road trip with demonic beings who clear his mind of ritual devotions and replace them with sinful acts. Unfortunately for Maghribīs and Andalusīs, these virtuoso demonic beings (shayāțin) inhabit the West; thus lay Muslims in the Islamic West must guard themselves against the slightest desire to go East, even for the loftiest of purposes.

This narrative represents a very different kind of fiction than 'Alī b. Yūsuf's concern for his subjects' souls. Yet both the crafting of a legitimate religiolegal argument to further a political agenda and the use of storytelling to communicate some aspect of the law are equally at home in Islamic legal literature.

48 Al-Burzulī, Jāmi‘ masā̄il al-ạ̣kām, 1: 594. 
Versions of this demonic beings story reappear in a prominent legal commentary by Muhammad al-Hatțāb, as well as in the fatwās of 'Abd al-Salām alTājūrī, Muhamammad Bello and 'Abd al-Hādī al-Ṣiqillī. The narratives, likely developed and shared in study circles or sermons, would have served as entertaining morality tales that communicated to a broader public the jurists' disapproval of common pilgrimage practices. Much is left to the imagination, and the audience for these accessible versions of the law may have extended well past the typical male audience of legal texts. What wife or mother would feel at ease as the single male subject of the story leaves his family and succumbs to a host of unnamed temptations?

Despite al-Burzulī's inclusion of this cautionary tale, he offers conditional support not only for performing the pilgrimage, but also for sailing with Christians. In commenting on the first question posed to al-Lakhmī, regarding the permissibility of travelling by sea, al-Burzuli notes that it is common practice in his time to travel aboard Christian ships from Ifrīiyā to Alexandria. One of his shaykhs, al-Burzuli tells us, believed this temporary submission to Christian authority to be analogous to travel to enemy territory for the purpose of trade. Many Mālikī jurists prohibited any travel that would force Muslims to fall under the jurisdiction of "infidel" laws. For this reason, al-Burzuli includes alMāzarī's lengthy fatwa a prohibiting travel to Christian Sicily for trade in this pilgrimage chapter. Nonetheless, al-Burzuli is not convinced that these opinions apply in his own time. He cites favorably a much more permissive opinion:

The correct opinion today is that it [viz., the permissibility of travel on Christian ships] depends on the conditions (khiläf fi hăal). If the ruler of Tunis is strong, such that the Christians would fear him if they were to engage in treachery or sour relations [with Muslims], then this is not a serious matter; and if not, then it is dangerous. ${ }^{49}$

Al-Burzuli concludes that sailing with Christians is permissible so long as Muslim pilgrims trust in the power of their own state to protect them, and so long as the benefits outweigh the harm. Within a small corpus of Mālikī opinions on not performing the pilgrimage, al-Burzuli is thus strikingly permissive.

Al-Burzuli's position may be a practical response to Ḥafșid power in the late fourteenth and early fifteenth centuries. ${ }^{50}$ Abu Fāris' lengthy reign (1394-1434)

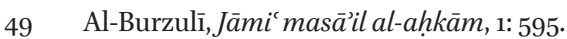

5o On the Ḥafșids, see Ramzi Roughi, The Making of a Mediterranean Emirate: Ifrìqiya an and Its Andalusis, 1200-1400 (Philadelphia: The University of Pennsylvania Press, 2011). In a short 
represented the height of Hafșid power and stability. For al-Burzulī, however, the limited guarantee of greater security afforded by this favorable balance of power appears to have extended only to the sea route. Sailing with Christians was thus far safer than traveling overland through Muslim territory. ${ }^{51}$

Musā b. 'Alī al-Wazzānī, 16th-century Far Maghrib

By the sixteenth century, the Christian-Muslim frontier had shifted from Iberia to North Africa. Beginning with the 1415 conquest of Ceuta, Portugal spent the fifteenth and early sixteenth centuries capturing nearly all of Morocco's major ports on the Atlantic and Mediterranean coasts, building fortresses and trading posts, and expanding their control inland, where feasible and profitable. Meanwhile, Castile accepted the surrender of Granada, Iberia's last Muslim kingdom, in 1492, and began its own program of conquest along the southern shore of the Mediterranean with the 1497 capture of Melilla, which remains a Spanish enclave to this day. ${ }^{52}$

Abū 'Imrān Musā b. 'Alī al-Wazzānī (d. 969/1561-2) ${ }^{53}$ was a Jazūlī Ṣūfĩ and descendant of the prophet Muhammad (sharif) whose lifetime coincided with the final expansion and then retraction of Portuguese holdings, the fall of the

article, Hassan Khalilieh argues that a decline in Muslim sea power in the Mediterranean beginning in the eleventh and twelfth centuries may explain some of the Mālikî fatwās that discourage the pilgrimage. Al-Burzuli's comments lend some support to Khalilieh's argument. Yet al-Lakhmī, the only other jurist to address travel by sea, assigns it no greater danger than travel by land. The Christian-Muslim power dynamics in the Mediterranean may have been an additional, unstated source of concern in many of these fatwās. Most of the jurists included in the Míyār (Khalilieh's source) and elsewhere who discourage or prohibit the pilgrimage do so regardless of the route (land or sea) and for a variety of reasons (or pretexts). See Hassan Khalilieh, "The Legal Opinion of Maliki Jurists Regarding Andalusian Muslim Pilgrims Travelling by Sea during the Eleventh and Twelfth Centuries CE," Mediterranean Historical Review 14.1 (1999): 59-69.

Al-Burzulī's teacher Ibn 'Arafa (d. 803/1401) is reported to have described the territory controlled by Bedouin tribes as dār al-harb because the Ifriqiyan army could provide no security against them. Al-Burzulì's contemporaries also forbade the sale of weapons to the Banū Ḥilāl, a prohibition normally applied to non-Muslims in dār al-ḥarb. Al-Burzulī, Jāmi‘ masāil al-ahkām, 28.

On the history of Morocco in the fifteenth and sixteenth centuries, see Vincent Cornell, The Realm of the Saint: Power and Authority in Moroccan Sufism (Austin: University of Texas Press, 1998); Weston Cook, Jr., The Hundred Years War for Morocco: Gunpowder and the Military Revolution in the Early Modern Muslim World (Boulder: Westview Press, 1994); Scott Kugle, Rebel Between Spirit and Law: Ahmad Zarruq, Sainthood, and Authority in Islam (Bloomington: Indiana University Press, 2006).

Muhammad b. 'Alī b. 'Askar (d. 986/1578), Dawhat al-nāshir li-mahāsin man kāna bì' 
Watțāsids, and the rise of the Sa'dīan dynasty. A disciple of 'Abd Allāh al-Habtī (d. 963/1555-56), ,4 al-Wāzzānī appears to have lived in Shafshāwan, originally founded as a northern garrison for jihād against the Portuguese. ${ }^{55}$ Al-Wazzānī's identity as both Ṣūfĩ disciple and Mālikī jurist was not uncommon in the Far Maghrib, nor did the Șûfĩ orders have a monopoly on social critique or military engagement. As this text will illustrate, fatwās were also used to promote military resistance to European encroachment and to articulate social and political critique. ${ }^{56}$

In the undated fatwa , al-Wazzani is asked if the obligation to perform the pilgrimage has lapsed for the people of the Maghrib. ${ }^{57}$ If so, is its performance prohibited, permitted, or reprehensible? The unnamed questioner asks further if the imām may prohibit Maghribīs from setting forth, considering that most pilgrims are unsuccessful in their journey because of the dangers they face, and considering that they are abandoning jiha d, even though the enemy's presence in their lands has made this an individual duty (fard 'ayn) for them. Finally, the questioner asks if the imām may appropriate from these would-be pilgrims their travel funds and use them instead to ransom Muslim prisoners of war - or, he asks, "is this not permitted, and they may spend their money on the pilgrimage, seeing as no mind is paid to prisoners of war in our time?"

The questioner clearly hopes for an answer that will confirm his conviction that the hajj is an unacceptable use of human and financial resources so long as European Christians occupy substantial territory in Morocco and hold untold numbers of Muslim captives. ${ }^{58}$ In addition to the propaganda value of an

Maghrib min mashāyikh al-qarn al-āshir, ed. Muḥammad Ḥajjī, 3rd ed. (Casablanca: Manshūrāt Markaz al-Tūrāth al-Thaqāfĩ al-Maghribī, 2003), 42-43.

Al-Habțī was a prominent Jazūlī reformer and social activist based in Shafshāwan. See Ibn 'Askar, Dawhat al-nāshir, 15-21; Cornell, Realm of the Saint, 266-69.

55 Cornell, Realm of the Saint, 243.

$5^{6}$ On fatwās as a means of resistance against the Portuguese, see Hendrickson, "Muslim Legal Responses to Portuguese Occupation in Late Fifteenth-Century North Africa," Journal of Spanish Cultural Studies 12: 3 (2011): 309-25.

57 This fatwā is preserved in al-Jawāhir al-nafisa fi-mā yatakarraru min al-hawādith al-gharība ("Precious Jewels Concerning Difficult Recurring Cases"), compiled by 'Alī b. 'Abd al-Salām al-Tasūl̄i (d. 1258/1842). Tunisian National Library, Tunis, ms. 5354, folio 171a-b. Al-Tasūlī, a Moroccan chief judge of both Fez and Tetouan, is best known (in modern scholarship) for his answers to Algerian resistance leader 'Abd al-Qādir's questions on jihād. Al-Jawāhir al-nafiss remains unedited and unpublished.

$5^{8}$ The taking of captives and corresponding ransom industry were a primary feature of Muslim-Christian relations in the Mediterranean in general, and the Far Maghrib in particular. The brother of al-Wazzānī's master, al-Habtì (d. 963/1555-56), suffered for twenty years in Portuguese prisons prior to being ransomed (Cornell, Realm of the Saint, 266.) On 
answer that would amplify his critique and call to action, he is requesting that juridical pressure be put on the "imām" to seize the funds - if not the able bodies - of anyone attempting to leave for the pilgrimage. The questioner feigns no concern for the relative salvific value of $j i h \bar{a} d$ or hajj for the individuals in question; instead, would-be pilgrims are characterized as defectors, and the seizure of their funds as a necessary measure for the communal good. It is likely that this question was posed by an irregular warrior (mujāhid) in Shafshāwan, one of thousands committed to resisting Portuguese and Spanish occupation. The "imām" likely refers to the Banū Rashīd who ruled Shafshāwan, rather than to the Watțāsids in Fez, who signed several peace treaties with the Portuguese. The Banū Rashīd ruled independently until 1495, and only recognized Watțāsid rule when forced to do so by a joint Portuguese-Watțāsid offensive; Shafshāwan renounced this allegiance in favor of the Sa'dians in $1541 .{ }^{59}$

Al-Wāzzānī is far less bold than the mustaftī in his answer, but nonetheless supports his questioner's emphasis on the priority and urgency of jihād. He begins with the cautionary phrase "if the matter is as you say," indicating that he is not personally endorsing his questioner's presentation of the facts. He then reproduces Ibn Rushd's first full fatwa and addendum declaring the hajj reprehensible for Andalusīs and Maghribīs, and the jihā $d$ a far greater priority. To this al-Wazzāanī adds a few short notes regarding the permissibility of performing the pilgrimage before addressing the issue of pilgrims' funds. ${ }^{60}$

captive-taking and the ransom industry, see Nabil Matar, Europe Through Arab Eyes, 15781727 (New York: Columbia University Press, 2009); Francesca Trivellato, Leor Halevi, and Cátia Antunes, eds., Religion and Trade: Cross-Cultural Exchanges in World History, 100o1900 (New York: Oxford, 2014), esp. the bibliography Kathryn Miller includes in her chapter ("Reflections on Reciprocity: A Late Medieval Islamic Perspective on Christian-Muslim Commitment to Captive Exchange"), p. 135; Russell Hopley, "The Ransoming of Prisoners in Medieval North Africa and Andalusia: An Analysis of the Legal Framework," Medieval Encounters 15: 2-4 (2009): 337-54; Camilo Gómez-Rivas, "The Ransom Industry and the Expectation of Refuge on the Western Mediterranean Muslim-Christian Frontier, 10851350," in The Articulation of Power in Medieval Iberia and the Maghrib, ed. Amira Bennison, Proceedings of the British Academy (Oxford: Oxford University Press, 2014), 217-32. Cornell, Realm of the Saint, 243-4, 269.

6o These notes include opinions on the amount a pilgrim might be expected to pay an oppressor enroute and still be obligated to perform the pilgrimage, and whether ability is a condition of obligation or performance. Al-Wazzānī also includes an observation made by Ibn Ṭalḥa al-Yāburī, an Andalusī who travelled from Evora (modern-day Portugal) to Mecca in the early 500s/110os. In the Maghrib, he encountered people who believed the pilgrimage to be not only in abeyance for the people of the Maghrib, but also prohibited. Abū Bakr 'Abd Allāh b. Ṭalḥa al-Yāburī al-Ishbīlī recorded his observations in al-Madkhal, a work of figh dedicated to the Zīrid sultan Tamīm b. al-Mu'izz (r. 1062-1108). He died in 
He begins with a general statement of Mālikī doctrine: The most widely accepted rule is that ransom funds must first come from the Public Treasury (bayt al-māl), but some scholars held that it should come from the prisoner's own money first, and secondarily from the Public Treasury. Al-Wāzzānī adds that if this money - presumably from both sources - is not enough or obtaining it is not possible, the responsibility to produce the ransom money falls on all Muslims, each according to his means. No one person may be held responsible for contributing ransom money, other than his fair share as part of a collective. As for the current situation, in which pilgrimage travel is reprehensible or prohibited, al-Wazzānī continues, any money donated to the pilgrim to help fund his journey must be returned. If the donors are unknown, the money must be given as charity (șadaqa), with a preference for the ransoming of prisoners. If the would-be pilgrim refuses to comply, either by insisting upon travel or upon keeping the money given to him, it is obligatory upon anyone with the power to stop him to do so and to seize his money. This money is again returned to the donors, if known, or given in charity, if not. Al-Wazzānī concludes that people must spend of their wealth in accordance with their own consciences.

Al-Wazzānī's fatwā attests to an established, but flexible, Mālikī tradition of prohibiting the pilgrimage that could be manipulated and enhanced to fit new contexts. Ibn Rushd's fatwā is deployed as an authoritative precedent establishing both the priority of jihād over the hajj and the sin of anyone attempting the pilgrimage. Al-Wazzānī then extends the implications of this precedent to the financial dimensions of both jiha $\bar{d}$ and hajj, treating captive redemption as a natural concomitant of war. Thus, would-be pilgrims - at least those who have accepted the contributions of others - must be prevented from squandering these funds on the pilgrimage, and ransoming should be considered the best alternative use of that money. Yet al-Wazzānī avoids placing responsibility on any one individual, either the imām or those who possess discretionary funds. In tempering his questioner's hopes, he avoids a response that could be understood as too strong a critique against his ruler or the wealthiest members of his society.

This fatwa is not state-sponsored and dissemblance does not feature strongly in it. ${ }^{61}$ Yet the text is a clear example of the way in which Mālikî fatwās that discouraged the hajj served to promote regional communal interests over indi-

Mecca sometime after 519/1125. For his biography, see Makhlūf, Shajarat al-nūr, 1: 190-1. Al-Wansharīsī includes an abbreviated version of Ibn Ṭalḥa's story directly after Ibn Rushd's fatwā in al-Mi'yār (1: 433).

61 References to "the enemy" and "the imām" remain oblique, as is typical in legal opinions. 
vidual desires, connection with the broader umma, or claims regarding the authority or centrality of the Hijāz. The Jazūlīya order encouraged visitations to local shrines or living shaykhs in place of the pilgrimage to Mecca, partly in order to solidify a regional identity and strengthen local networks. ${ }^{62}$ This first fatwa to emphasize the strategic importance of keeping wealth at home, alongside able bodies, complements the order's focus on local saints while mobilizing physical and financial resources toward jihād and captive redemption.

\section{7}

Al-Täjūrì, 17th to 18th-century Libya

'Abd al-Salām b. 'Uthmān al-Tājūrī (d. 1139/1727) lived in Ottoman Tripoli, where he compiled Tadhyül al-Mi'yār, a five-volume compilation of Mālikī fatwās. ${ }^{63}$ As the name suggests, this work was intended to supplement alWansharīsì's al-Mi'yār al-Mu'rib by bringing together legal opinions issued in the eleventh/seventeenth and twelfth/eighteenth centuries, from Egypt to Morocco. In his chapter on the hajj, al-Tajjūrì includes a lengthy opinion of his own on the permissibility of undertaking the pilgrimage. ${ }^{64}$ While he rehearses the opinions or stories of al-Lakhmī, al-Māzarī, Ibn Rushd, and al-Burzulī, al-Tājurī also introduces new concerns, arguments, and jurists.

Al-Täjurì's fatwa $\bar{a}$ is the first in this series to be centrally concerned with women's ability to undertake pilgrimage travel. He considers a case involving a woman whose husband cannot perform the hajj, presumably because of his physical condition. She wanted to travel from North Africa (ard al-Maghrib, possibly Morocco) to Mecca with a third party, who was neither her husband nor a mahram, a close male relative. This is not permissible, she was told, because the "ability" to perform the pilgrimage for both men and women, equally, requires the safety and security of their persons and property - and this security is completely nonexistent for the inhabitants of North Africa. Thus, she does not qualify as "able" to travel.

While the specific question is unclear, al-Täjūrīs task appears to be a defense of this prior position with which the woman was confronted. He supports the position that she is "unable" to perform the pilgrimage by showing that proper accompaniment is an additional requirement for women, beyond

62 Cornell, Realm of the Saint, 180.

63 'Abd al-Salām b. 'Uthmān al-Tājūrī (d. 1139/1727), Tadhyūl al-Mi'yārr, ed. Jum‘a Maḥmūd al-Zurayqī, 6 vols. (Benghazi: Dār al-Kutub al-Wațanīya, 2008). The sixth volume is devoted to indices. On his life and works, see al-Tājūrī, Tadhyül al-Míyārr, 1: 13-104.

64 Al-Tājūrī, Tadhyül al-Mi'yār, 2: 64-72. This section begins with "qultu," the standard way for a compiler to introduce his own opinion on a topic under discussion. Here, the phrase introduces a new topic and may respond to a question posed to al-Tājūrī while he was compiling these volumes. 
meeting the same standard of security required of men; but since men cannot meet this standard in the present age, how much more implausible is it for a woman to do so? For women, he says, the obligation to perform the pilgrimage is a condition of its permissibility, especially for a woman wishing to travel without her husband. According to al-Tājurī, women are even less likely than men to perform their daily prayers while travelling, given their track record at home.

Much of al-Tājūrì's discussion is devoted to establishing that the region's Muslims in general - and women in particular - are not obligated to perform the pilgrimage. He reviews the opinions of each jurist noted above, including al-Māzarī's definition of ability, which includes the regular performance of ritual obligations. Two new jurists are also introduced, 'Alī b. Muhammd alAjhūrī (d. 1066/1656) ${ }^{65}$ and Muhammad b. Muhammad al-Rāīi (d. 853/1449$50),{ }^{66}$ both of whom were active in Egypt. Al-Ajhūrī is al-Tājūrīs source for al-Rāî̀'s opinion, cited favorably by al-Ajhūrī in order to emphasize that it is not just Maghribīs for whom the pilgrimage is forbidden. According to al-Rāî̀, learned scholars - North Africans and Egyptians alike - had reached a consensus that pilgrimage travel is not permissible in "these times" for any reason. The reasons cited include neglect of the five daily prayers, the risk to one's life and property, and the conflicts and disorder to be encountered. Al-Ajhūrī notes that another of his shaykhs added to the list the preparation of food in filthy conditions, and that someone - possibly al-Rāi - confirmed all these conditions to be the current reality during his own hajj journeys, by both land and sea. Finally, al-Ajhūrī declares the hajj non-obligatory for the additional reason that water is not reliably available along the route.

In addition to these new and old arguments, al-Tājūrī introduces a novel logical argument of his own. He reasons that if earlier scholars prohibited the pilgrimage for everyone, including women accompanied by their husbands, how could a woman be allowed to travel without proper accompaniment in his own time? Twice in the course of his discussion, al-Tājūrī makes the argument that people are less righteous and trustworthy than in the past. ${ }^{67}$ As many of

65 Al-Ajhūrī was an Egyptian Mālikī jurist who authored a number of works on law, hadīth, and linguistics. His fatwās were compiled by one of his students and many of them appear in Tadhyül al-Mi'yār. Makhlūf, Shajarat al-nūr, 1: 439-40.

66 Muhammad b. Muhammad b. Muḥammad b. Ismā̄îl, known as al-Rāc̄ī, was born in Granada ca. $780 / 1378$ but moved to Cairo in 825/1422. He performed the pilgrimage. See 'Umar Riḍā Kaḥhāla, Mújam al-mu’allifiñ, 4 vols. (Beirut: Mu’assasat al-Risāla, 1993), 3: 675; Aḥmad Bābā al-Tinbuktī (d. 1036/1637), Nayl al-ibtihāj bi-tațrìz al-Dībāj, ed. 'Alī 'Umar, 2 vols. (Cairo: Maktabat al-Thaqāfa al-Dīnīya, 2004), 2: 210.

67 Al-Tājūīī, Tadhyül al-Míyārr, 66 and 70. 
the dangers of the pilgrimage route result from human conflict and treachery, and the performance of prayers along the way accords with a traveler's piety, al-Tājūrì is able to argue that the overall quality of human beings in any given age affects the general "ability" of Muslims to perform the pilgrimage. He does not elaborate on the conditions of his own time, but assumes that people become less virtuous with each passing generation.

Al-Täjūrìs argument is tempered only slightly by three opinions softening or critiquing this Mālikì discourse discouraging the pilgrimage. He includes alMāzarì's story in which al-Lakhmī, challenged by an old man in his study circle, acknowledges a "Șufì path" exception to the rule. ${ }^{68} \mathrm{Al}$-Tàjūrī also records a critique by the Fāsī jurist Aḥmad Zarrūq (d. 899/1493), ${ }^{69}$ who critiqued his fellow scholars for saying that the obligation to perform the pilgrim was sāqit dropped, or not in effect - for the people of the Maghrib. ${ }^{70}$ Zarrūq agreed that Maghribīs should not go on hajj, but urged a more disciplined use of proper legal language. Like al-Māzarī and Ibn Rushd (in his second fatwā), Zarrūq preferred jurists to say that the ability to perform the hajj is nonexistent in the Maghrib, rather than that the obligation itself is inapplicable to the region's Muslims. Finally, al-Tājūīi notes that Ibn al-Arabī (d. 543/1148 $)^{71}$ objected that many who proclaim the hajj to be in abeyance for Maghribīs nonetheless travel from place to place, confronting dangers and crossing seas, in pursuit of myriad religious and worldly aims. Al-Tājūin quickly explains, however, that Ibn al-'Arabī's complaint centers on the hypocrisy of those who say one thing and do another, and does nothing to override the well-established opinions of other scholars that the pilgrimage is indeed in abeyance.

While allowing these minor points of dissent, al-Tājūrī defends his position on the hajj against another possible critique. ${ }^{72}$ Why should a pious woman capable of fulfilling all her religious duties during travel be prohibited from performing the hajj just because most other women would falter? Al-Tājūrī notes that the opinions he has cited, as well as others left unmentioned, from

68 Al-Tājūrī, Tadhyül al-Mi'yārr, 68-69.

69 Aḥmad b. Aḥmad b. Muhammad Zarrūq (d. 899/1493), a Mālikī jurist from Fez. See al-Sakhāwī, al-Ḍaw’ al-lāmi', 1: 184-5; Makhlūf, Shajarat al-nūr, 1: 386-7; Muhammad b. Ja far al-Kattānī (d. ca. 1346/1927), Salwat al-anfās wa muhāàdathat al-akyās bi man uqbira min al-'ulamā' wa'l-ṣulaḥā' bi Fās, ed. 'Abd Allāh al-Kāmil al-Kattān̄̄, et al., 3 vols. (Casablanca: Dār al-Thaqāfa, 2004), 3: 225.

70 Al-Tājūrī, Tadhyül al-Mi'yār, $66-67$.

71 Abū Bakr Muḥammad b. 'Abd Allāh b. Muhammad, known as Ibn al-'Arabī (d. 543/1148), a prominent Mālikī jurist from Seville. See Ibn Farḥūn, al-Dībāj, 376-8; EI $I^{2}$, s.v. "Ibn al-'Arabī” (A. Ateş); Makhlūf, Shajarat al-nūr, 1: 199-201.

Al-Tājūrī, Tadhyül al-Mi'yār, 70-71. 
Mālik onwards, all operate by assessing what is general and probable for the majority of people. These rules are applied to everyone, rather than accounting for every possible case. Thus Mālik, al-Tājūrī notes, disliked women travelling at all, because of the general corruption of times - despite the fact that there were many (more) men beyond reproach in his day. Although al-Tājūrī implies that the same standard is applied to men and women - that of imposing on everyone rules based on the most probable cases - the consequences for women nonetheless diverge from those for men. If the obligation to perform the pilgrimage is a prerequisite for its permissibility in the case of women, then there can be no "Șufĩ exception" for devout women who desire to perform the hajj despite the widespread inability to do so.

\section{$8 \quad$ Al-Warzāzī, 18 th-century Morocco}

In a brief fatwā included in his own Nawāzil and al-Mahdi al-Wazzānī's alMíyār al-jadìd, Muḥammad b. Muḥammad al-Dalīmī al-Warzāzī (d. 1166/1763$4)^{73}$ is asked if some scholars hold that Maghribīs are not obligated to perform the pilgrimage. ${ }^{74}$ In response, al-Warzāzì summarizes the opinions of Ibn Rushd, Abū Bakr al-Ṭurțūshī, Abū 'Īmrān al-Fāsī, Abū Bakr 'Abd al-Raḥmān, and al-Māzarī, in that order. ${ }^{75}$ The opinions he presents are divided equally between those emphasizing non-obligation and prohibition. By adding no further commentary, al-Warzāzī tacitly supports the continued validity of these opinions in his own time.

\section{$9 \quad$ Muhammad Bello, 19th-century Sokoto Caliphate}

Muhammad Bello (1781-1837), who headed the Sokoto Caliphate from 1817-37, authored the most substantial Mālikī work discouraging the hajj in the form of a lengthy treatise entitled Awakening the Sleeper to Recognition of the Ways in

73 I have been unable to locate al-Warzāzī in biographical dictionaries. His death date reflects the one provided in Mubārak Jazā̄ al-Ḥarb, "Namādhij min juhūd fuqahā" al-Mālikīya al-Maghāriba fī tadwīn al-nawāzil al-fiqhīya," Majallat al-Sharî̃a wa'l-Dirāsāt al-Istāmīya 21: 64 (2006): 346.

74 Abū 'Īsā Muḥammad al-Mahdī al-Wazzānī (d. 1342/1923), al-Nawāzil al-jadīda al-kubrā fì-mā li-ahl Fās wa-ghayrihim min al-badw wa'l-qurā, al-musammā bi-: al-Mi'yār al-jadīd al-jāmi' al-mu'rib 'an fatāwì al-muta'akhkhirīn min 'ulamā' al-Maghrib, ed. 'Umar b. 'Abbād, 12 vols. ([Rabat]: Wizārat al-Awqāf wa'l-Shu'ūn al-Islāmīya, 1996-200o), 2: 229. Several manuscript copies of Nawāzil al-Warzāzi are extant in the Moroccan National Library, the Hasanīya (Royal) Library, and the Ṣbīhī Library. I consulted ms. 5768 at the Ḥasanīya and found al-Wazzānīs version to be a faithful rendering.

75 All of these opinions appear in the translated fatwās in the appendices. 
which a Pilgrim Can be Corrupted. ${ }^{76}$ Bello was a prolific scholar as well as a talented military commander and administrator. His father, Shaykh 'Uthmān b. Fūdī (1754-1817), or "the Shehu" Usuman Dan Fodio (in Hausa), was a trained scholar and Qādirī Ṣūī shaykh who led an Islamic reform movement in modern-day Northern Nigeria. ${ }^{77}$ Following a twenty-year period of travelling and preaching, Dan Fodio led a hijra in 1804 from his hometown of Degel to Gudu, just beyond the kingdom of Gobir. This marked the beginning of a successful four-year armed jihād (1804-08) against Gobir and its neighboring kingdoms in Hausaland and Bornu. Bello played a leading role in the military campaigns, founded the capital city of Sokoto in 1810, and succeeded his father as Commander of the Believers (amir al-mu'minin) upon the latter's death in 1817. The Caliphate, which lasted nearly a century until the British conquest in 1903, represented the largest independent state in nineteenth-century Africa.

The composition and length of Bello's undated treatise, in which he marshals over fifty earlier authorities and nearly two dozen hadith reports, was likely motivated by three primary factors: a desire to keep subjects' resources and Islamic aspirations at home; the need to justify Dan Fodio's and Bello's own inability to undertake the hajj, and the need to reconcile the adoption of anti-hajj rhetoric by a movement founded on Islamic reform. I will elaborate on each of these points following a brief summary of the treatise.

As the title suggests, Awakening the Sleeper is framed as a warning to wouldbe pilgrims of the myriad ways in which they might be corrupted and their hajj invalidated. Bello begins his treatise by stating that it is the duty of those who have been unable to perform the pilgrimage to lament this fact and to yearn for Mecca. Yet one must be careful, the ruler cautions, not to allow Satan to take advantage of this yearning to lure a good Muslim onto the road, where he will begin to neglect his prayers, engage in prohibited acts, and fail to provide for his family. With al-Burzuli's story regarding the demonic beings of the West and the East, Bello concludes his introduction.

In the body of the treatise, Bello argues six primary points. First, the obligation to perform the pilgrimage is conditional upon one's ability to undertake it. Bello endorses al-Māzarì's definition of ability, including the capacity to arrive

${ }_{76}$ Aisha Bewley has translated Kitāb tanbīh al-rāqid 'alā mā ya'tawiru al-ḥājj min al-mafāsid into English. It is available at https://bewley.virtualave.net/bellohajj.html. Accessed 10 June 2015 .

77 On Dan Fodio, the Sokoto Caliphate, and Bello, the best sources remain Murray Last, The Sokoto Caliphate (London: Longmans, 1967) and Mervyn Hiskett, The Sword of Truth: The Life and Times of the Shehu Usuman Dan Fodio (New York: Oxford University Press, 1973). The "Sokoto Caliphate" is a late twentieth-century term; Muslim authors called it the dawla Uthmānīya, the 'Uthmānic State. 
in Mecca safely and without great hardship, to perform all obligatory prayers, and to avoid all prohibited actions. He includes additional opinions to the effect that anyone who must travel by sea is forbidden to perform the hajj in dangerous conditions (Ibn Farhūn, d. 799/1397); that the hajj is not obligatory if it leads to the neglect of even one prayer (al-Hatțāb [d. 954/1547], Ibn alHaajib [d. 646/1248]), and that the pilgrimage is forbidden for anyone susceptible to omitting even one prayer during travel (Ibn al-Munayyir, d. 683/1284). Next come the sweeping statements of several jurists regarding the inability of Andalusīs or Maghribīs to perform the pilgrimage, including the opinions of Ibn Rushd and his contemporary Abū Bakr al-Ṭurțūshī (d. 520/1126), who prohibited all Maghribīs from attempting the pilgrimage because of a general lack of ability. Interestingly, Bello notes that while it is true that prayers may be disrupted for jiha $\bar{d}$, the same is not true of the hajj, which is a lower priority than both prayer and jihād.

Bello goes on to discuss whether or not ability is a condition of obligation or of validity and the extent to which water must be available along the route. But the most distinctive part of his "ability" section considers the particular circumstances of rulers. If a ruler's absence is likely to result in social disruption or conquest by unbelievers, then he lacks the ability and therefore the obligation to perform the hajj. Bello supports this determination with his own reasoning as well as that of al-Hațtāb (d. 954/1547, in Mecca).

Bello's second primary point is the importance of using lawful and sufficient funds for undertaking the hajj. A pilgrimage made with illegitimate funds, or as an ostentatious show of piety and wealth, is not valid. Embarking without sufficient funds produces a host of negative consequences for Muslims in general, not just the pilgrims: many poor pilgrims petition money from tyrants along the way, flattering them and contributing to their power; others beg for money as they go, burdening all those they encounter; and still others leave their families in distressed circumstances. All this, Bello laments, is caused by ignorance and a failure to consult the learned scholars.

Memorable stories punctuate the legal proof-texts in Bello's narrative and help illustrate his points. In one, a man who stole money from a companion to finance his hajj died along the way. The men who buried him left a pickaxe in his grave and tried to retrieve it by disinterring him. When they reached his body, they found the blade joined to his head and neck. In another story, the ascetic Bishr al-Hāfî̀ ${ }^{78}$ interrogated a man about his true motivations for performing the pilgrimage. When the man claimed his only desire was to please

78 Abū Nașr Bishr b. al-Ḥārith (d. 227/841-2), known as al-Ḥāfì, "the Barefoot," was born near Merv and settled in Baghdad. $E I^{3}$, s.v. "Bishr al-Ḥāfi”" (Michael Cooperson). 
God, Bishr advised him to give his travel money in charity to poor men, debtors, or those caring for orphans or large families. Removing hardship from others and bringing them joy is better than a hundred pilgrimages, he said. When the man balked at giving away his money and expressed a strong desire to travel, Bishr warned that when money is acquired dubiously, it often leads to public displays of piety that will not meet with divine acceptance.

This concern for sincerity and the avoidance of ostentation is another of Bello's primary themes. He stresses that a Muslim who follows the sunna wherever he finds himself is nearer to God than a person who is in Mecca but whose heart is elsewhere. In one of the stories supporting this point, a man whose mother calls out to him at night finds himself slow to rise out of bed and get her a drink of water. The man then reassesses the annual pilgrimages he makes on foot, realizing that those journeys are easy for him because of the praise and recognition he encounters along the way. Bello repeatedly stresses the priority of true devotion to God, often expressed through the extension of aid to fellow Muslims, over an attempt to perform the hajj fraught with potential corruption, invalidation, and harm to others.

Bello's fourth point is the priority of $j i h \bar{a} d$ over pilgrimage. In addition to Ibn Rushd's fatwāa, Bello cites numerous prophetic hadīth reports and other traditions attesting to jiha a d's place of prominence as the most important Islamic duty after belief in God and his Prophet. In one tradition, Mu'a dh b. Jabal, a Companion of the Prophet, saddles and then unsaddles the mount he would ride into battle, declaring that action to be better than ten pilgrimages. In another story, a man is dissuaded from leaving his fellow warriors in order to perform the hajj when they assure him that by protecting Muslims, he will be granted the reward for all their completed pilgrimages in addition to the higher reward for fighting.

The importance of proper knowledge, noted above, is Bello's fifth primary point. In addition to using dubious funds or acting ostentatiously, many pilgrims with insufficient knowledge invalidate their pilgrimages by performing key elements incorrectly. Consultation with the scholars is essential because many Muslims are ignorant of the requirements for a valid pilgrimage.

Finally, Bello provides a wealth of traditions and stories suggesting and praising alternatives to the performance of the pilgrimage. Aside from the $j i h \bar{a} d$ of the sword, these include the jihäd of the self, making sacrifices to help others, remembrance of God (dhikr), and early arrival at Friday congregational prayers. While some of these actions are equivalent to a voluntary pilgrimage, in other cases the implication is that they render the obligatory pilgrimage unnecessary. For example, a man on the way to perform the hajj found a woman eating carrion, a prohibited food, out of necessity. He stopped to help her. That night, he learned in a dream that an angel had performed the hajj on his behalf. 
Notably absent from these stories and traditions is any mention of local alternative pilgrimages; nowhere does Bello suggest that a pilgrimage to Dan Fodio's grave or to any other local saint or shrine is the equivalent of the hajj. ${ }^{79}$

At least three political motivations may explain Bello's composition of Awakening the Sleeper, the most complex Māliki composition discouraging the hajj. He may have written the treatise during his twenty-year rule, when he struggled to consolidate the state founded by his father against both internal revolts and external attacks. His pilgrimage policy would have prevented conquered communities from emigrating under the pretext of the pilgrimage, encouraged loyal subjects to commit their physical and financial resources to the emerging state, and helped focus the people's Islamic aspirations on the doctrines, traditions, and sites central to Dan Fodio's reform movement.

A hajj journey from West Africa to Mecca may take several years and would have been impractical for either Dan Fodio or Bello. ${ }^{80}$ Awakening the Sleeper explicitly justifies their inability to perform the pilgrimage by making it clear that a ruler's priority is the maintenance of social order and the defense of his subjects. By casting aspersions on the validity and virtue of other Muslims' pilgrimages, the treatise would also have mitigated the challenge to their legitimacy that might have issued from other returning pilgrims. Those returning from Mecca, claiming the prestige of having completed the hajj and the acquisition of religious knowledge in the East, might well have posed a problem as a competing source of authority. While Dan Fodio's movement was not immune from Wahhābī influence, Wahhābī doctrines such as the rejection of saints and Șüfism were anathema to his doctrines and his own legitimacy (and legacy) as a religious and political leader.

The self-interest of Mālikī jurists in limiting access to the hajj in order to guard the exclusivity of their own religious authority likely plays a role in many of the fatwās discussed here. When a jurist complains that pilgrims neglect their prayers on the road, at least one of his concerns may be the deference and heightened religious status acquired by wealthy individuals who can afford the journey and return as accomplished hăjjiss, even if they are not particularly pious. This resentment would be exacerbated if the jurists themselves were generally unable to make the pilgrimage. ${ }^{81}$

79 Sokoto became a major center for pilgrimage in Hausaland after Dan Fodio's death. Last, The Sokoto Caliphate, 60.

80 Dan Fodio did set out on the hajj once as a young man, but was commanded to return by his father. Hiskett, The Sword of Truth, 23-24. He composed poems expressing his desire to visit Mecca and Medina.

81 In her work on modern-day Guinean immigrants in Portugal, Michelle Johnson has observed a somewhat similar phenomenon. In the Mandinga community with which she worked, most believed that the pilgrimage should be performed only later in life, and that 
While the political utility of Awakening the Sleeper is evident, a treatise warning against performance of the hajj might seem an odd fit in the context of a reform movement devoted to the Islamicization of a nominally Muslim population. Dan Fodio sought to increase adherence to a normative version of Islam informed by both Mālikī law and Qādirīya Șūfì practices. While the movement he founded did win new converts to Islam, its central focus was the "mixed" Islam of Muslims who maintained pre-Islamic customs and animist religious practices. Through a combination of preaching, dissemination of written materials, and armed jihäd, the reform movement eventually succeeded in transforming Islam in northern Nigeria. Yet to champion a stricter, purer form of Islam while discouraging one of the Five Pillars likely produced a significant discomfort that explains the length and complexity of Awakening the Sleeper. Bello builds the strongest possible case, in part to overcome this tension between Islamization and avoidance of the hajj.

Like many earlier fatwās, Awakening the Sleeper engages fully in two modes of fiction. The political concerns most likely to have motivated its composition and dissemination are masked by the display of every proof-text and legal argument that can be mustered to convince individual Muslims that performance of the hajj would be to their own personal detriment. To render these arguments intelligible and memorable for a mass audience, Bello includes myths and stories at regular intervals, from demonic beings luring unsuspecting men onto the road, to angels who dispatch the hajj on behalf of anyone good enough to forgo the journey to help others.

\section{Abd al-Hādì al-Siqillì, 19th-century Morocco}

Bello's treatise proved so compelling that it served as the unacknowledged basis for a later fatwā issued by 'Abd al-Hādī al-Ṣiqillì (d. 1311/1893). ${ }^{82}$ As chief judge of Fez, al-Ṣiqillī was asked by the Moroccan king al-Ḥasan I (r. 1873-1894) if would-pilgrims should be allowed to set forth without sufficient resources. ${ }^{83}$ The text is undated but must have been written between 1873 and 1893, after al-Ḥasan I assumed power and before al-Ṣiqillī left Morocco to perform the pilgrimage, from which he never returned. This text represents the clearest,

a hajj performed too young would be "spoiled." Their reasoning is that the pilgrim must be ready to devote him or herself fully to Islam upon return, and to take full advantage of the opportunity to cleanse past sins. I am grateful to Johnson for sharing an unpublished draft chapter with me.

82 'Abd al-Hādī b. Aḥmad al-Ḥusaynī al-Ṣiqillī (d. 1311/1893), chief judge of Fez. On him, see al-Kattānī, Salwat al-anfās, 1: 148; al-Ziriklī, al-A'ām, 4: 172. In an earlier article, I mistakenly referred to al-Ṣiqillī as Aḥmad al-Siqillī. Hendrickson, "Is al-Andalus Different?", 401.

83 See Appendix D for a full translation and discussion of sources. 
most pronounced example of politically motivated dissemblance in the texts studied here.

The question begins by describing an issue of current concern, namely, people setting forth on the journey toward Mecca without sufficient resources. Three primary problems are identified: the would-be pilgrim willfully exposes himself to danger, he often does not succeed in completing the pilgrimage, and he humiliates both himself and his religious community in front of Islam's enemies, the Jews and Christians. Al-Hasan I refers to the experience of Muhammad and to the Qurān in order to establish that the obligation to perform the pilgrimage is conditional upon the ability to do so. He then quotes a short definition of "ability" from the Mukhtașar of Khalīl b. Ishạa (d. 776/1374), an influential Mālikī textbook, stating that this ability consists of the capacity to arrive in Mecca without great hardship or danger to one's person or property. Finally, he asks whether or not would-be pilgrims who do not possess sufficient means to undertake the journey should be prevented from doing so.

Al-Ṣiqillì begins his response by stating that it is a tenet of Islam that the pilgrimage is a pillar of the religion, meaning that not only is it obligatory to perform the pilgrimage, but Muslims must believe this to be an obligation. He cites three types of evidence in support of this statement: one verse from the Qurān (3:97), one hadìth report, and the consensus of the community. AlȘiqilli then addresses the scholarly disagreements related to the condition of "ability." He summarizes a discussion in al-Haț̣āb's Mawāhib al-jalīl, concluding that the prevailing position within the Mālikì school is that the ability to undertake the pilgrimage is a condition of its obligation, not of its validity. As for the definition of ability, al-Șiqilli first presents the four schools as being in agreement with regard to the basics of the concept: It is the capacity to arrive in Mecca safely and securely, without great hardship; and this generally requires sufficient provisions and an animal for riding. He also notes that Mālik allows a pilgrim to travel on foot without full provisions, provided that he practices a trade by which he can support himself along the way; and that al-Māzarī further requires that he be able to perform all ritual obligations during the journey, a point that al-Siqillī discusses in detail later in the text.

Al-Șiqilli then addresses the consequence of not meeting this standard for ability, which is exemption from the obligation to perform the pilgrimage: "Whoever does not have the ability to undertake the pilgrimage, does not have the obligation." 'Abd al-Hādì notes that this exemption is especially applicable to the type of would-be pilgrim described in the question to which he is responding. He then cites the fatwās of Ibn Rushd and Abū Bakr al-Ṭurțūshī, along with Aḥmad Zarrūq's statement that all Maghribīs are indeed incapable of performing the pilgrimage. 
Al-Siqillī then discusses four specific problems that result from pilgrims setting forth on the pilgrimage despite their failure to meet the condition of ability: they expose themselves to financial and physical loss or ruin, which presents a prohibited and sinful degree of risk; they fail to fulfill their ritual obligations during the journey, neglecting not only their daily prayers but often the requirements that make the hajj rituals themselves valid; they place a great burden on those who are asked to provide for them along the way, thereby implicating these well-wishers in their sin; and they humiliate themselves. AlȘiqilli, who is most concerned with the issue of improperly performed prayers, cites numerous authorities who stress that even one potentially missed or delayed prayer is enough to remove the obligation to perform the pilgrimage, that a person who knows he will miss a prayer must not undertake the journey, and that the merits of performing the pilgrimage will not compensate for failing to perform the prayers. The one adjustment to a pilgrim's prayers that is allowed, but only by some authorities, is that of omitting the standing portion of the prayer, as might be necessary aboard a ship, for one prone to seasickness or who fears falling overboard. It is not permissible to omit the prostration for any reason, including crowded conditions aboard a ship.

The final authority cited by al-Ṣiqillī is Ibn 'Abbād (d. 792/139o), a prominent Șūî of the Shādhilī order as well as a Mālikī jurist. The citation emphasizes the spiritual refinement, purity of intention, and religious knowledge necessary for undertaking the pilgrimage in a manner that will be completely praiseworthy. Any pilgrimage motivated by the desire to enhance one's reputation, on a whim, or by incomplete knowledge is partly or wholly blameworthy.

Al-Ṣiqillī concludes by succinctly answering the original question posed. Those fitting the condition described in the question, meaning those who lack the means to complete the journey, should not be permitted to set out either on their own or with any kind of help. That these would-be pilgrims do not meet the condition of ability clearly stipulated in the Qurān is agreed upon across all of the law schools. Al-Siqilli’s final policy recommendation is that the ruler is not only authorized but also obligated to put in force a general rule ensuring compliance with the legal requirements of the pilgrimage. He closes with a long prayer in praise of al-Ḥasan I.

Like Awakening the Sleeper, al-Ṣiqilli’s text no doubt supported a state policy limiting or blocking departures for the pilgrimage. Al-Ṣiqillī was writing after Algeria and Tunisia had become French colonies and in the last few decades before Morocco officially became a French protectorate in 1912; al-Hassan I was, like Bello, likely motivated by a desire to keep the financial and physical resources of his subjects focused on the welfare of Morocco. 
What is most striking about al-Șiqillì's text is his omission of both of the pressing concerns that led to France's prohibition of the pilgrimage during the same time period: disease and dangerous ideas. Colonial powers within Muslim territories formulated their hajj policies with care, weighing the religious sensibilities of their subjects against the threats posed by what William Roff has described as a source of "twin infection;" the pilgrimage was feared as a source of both epidemic diseases and Pan-Islamic, revolutionary propaganda. 84 In North Africa, the French chose to prohibit the pilgrimage for at least fifteen of the twenty-six years between a devastating cholera epidemic in 1893 and the close of World War I in 1918. ${ }^{85}$ Correspondence between French officials urging a reinstatement of the pilgrimage in 1919 points to their concerns that the natives may have difficulty in continuing to accept the administration's pretexts for prohibiting this sacred Islamic duty, that France's reputation was suffering while the British and Dutch earned praise for supporting the pilgrimage, and that, at any rate, prohibiting the hajj would not prevent North Africans from learning about events elsewhere in the Muslim world. ${ }^{86}$

The omission of disease as one of the dangers faced by pilgrims is striking, given al-Ṣiqillì's treatment of seemingly every other reason not to perform the hajj. From 1865 to 1892 , at least eight cholera epidemics struck Mecca and Medina. Indeed, al-Șiqillì himself perished, along with much of his family, during the catastrophic 1893 hajj, in which an estimated 33,000 out of 200,000 pilgrims

84 William Roff, "Sanitation and Security: The Imperial Powers and the Nineteenth Century Hajj," Arabian Studies 6 (1982): 143. See also Michael Christopher Low, "Empire and the Hajj: Pilgrims, Plagues, and Pan-Islam under British Surveillance, 1865-1908.” International Journal of Middle Eastern Studies 40 (2008): 269; and Eric Tagliacozzo, "Hajj in the Time of Cholera: Pilgrim Ships and Contagion from Southeast Asia to the Red Sea," in Global Muslims in the Age of Steam and Print, ed. James Gelvin and Nile Green (Berkeley: University of California Press, 2014), 103-20.

85 This estimate is based on my review of documentation related to the hajj in the Tunisian National Archives (Les Archives Nationales de Tunisie), especially boxes A-0276 bis-oog001 (1898-1899) and A-0276 bis-001-001 (1885-1920). According to Benjamin Brower, France prohibited the pilgrimage from Algeria twenty-two times between 1875 and 1915; the same figure likely applies to Tunisia. Benjamin Claude Brower, "The Colonial Hajj: France and Algeria, 1830-1962," in The Hajj: Collected Essays, ed. Venetia Porter and Liana Saif (London: The British Museum, 2013), 111.

86 Le Gouverneur général de l'Algérie to M. le Ministre des Affaires étrangères, 2 July 1919. Les Archives Nationales de Tunisie, box A-0276 bis-003-0014 (1919-1920), document 24. This letter primarily concerns Algeria but reflects the French position in both territories. The administration's "pretext" was public health, which, while valid, disguised their greater political concerns regarding anti-colonial agitation. 
died of cholera in the Hijaz alone. ${ }^{87}$ Contemporary accounts describe Meccan authorities as unable to keep up with the burial of decaying human corpses, while thousands of sacrificed animals were left unattended and putrefying in the June heat. 88

What should we make of al-Ṣiqillīs preoccupation with missed prayers in the face of recurring cholera epidemics that commanded international attention and resources (and that would claim his own life), increasing European penetration of Morocco, and aggressive colonialism in Tunisia, Algeria, and Egypt? This fatwa, which constitutes the most extreme example of dissemblance in this series of Māliki fatwās discouraging or prohibiting the pilgrimage, is shaped by three familiar factors: the local political concerns of a ruler, a jurist's translation of those concerns into a document constrained by the language and parameters of the law, and the need to express the desired policy outcome and its justification in terms intelligible and acceptable to the public. 89

Al-Hasan I's political interests are the least transparent of these three factors; unfortunately, we have no equivalent to the later French correspondence to distinguish pretext from genuine concern. Yet there are ample candidates for his desire to secure a fatwa legitimizing restrictions on the hajj. Cholera would have been a genuine concern, but al-Ḥasan I likely preferred to avoid associating himself either with France's rationale for prohibiting the pilgrimage or with unpopular European quarantine systems. The phenomenon of destitute pilgrims humiliating themselves and, by extension, their country, may have been a real concern. Al-Șiqilli's fatwā masked the inability of the state to protect or sponsor its own pilgrims, and allowed al-Hasan's officials to hand-

87 F.E. Peters, The Hajj: The Muslim Pilgrimage to Mecca and the Holy Places (Princeton, N.J.: Princeton University Press, 1994), 303.

88 Peters, The Hajj, 303-4 and 309.

89 A fatwā from British India roughly contemporary with that of al-Siqillī provides another instructive point of comparison with non-Mālikī opinions. Maulana Rashid Ahmad Gangohi (1829-1905), one of the founders of the Deobandi school, was asked in 1893 if a pilgrim should visit Medina after the hajj. Or is the additional trip so dangerous and expensive as to incur sin? The mufti dismisses safety as a valid argument since safety is a matter of chance, and he castigates anyone unwilling to spare the cost of a train ride to visit the "blessed sepulchre of the lord" as defective in faith and love. The brevity of this fatwā suggests that Hanafi jurists did not have a tradition of exempting Indian Muslims from performing the hajj because of the danger of the route; otherwise, Gangohi may have found it necessary to marshal additional arguments. See Barbara Metcalf, "Two Fatwas on Hajj in British India," in Islamic Legal Interpretation: Muftis and Their Fatwas, ed. Masud, Messick, and Powers (Cambridge, MA: Harvard University Press, 1996), 184-5. 
pick presentable and trustworthy elites to represent Morocco in front of "Islam's enemies," as well as fellow Muslims of different political inclinations. Al-Hasan would have shared Bello's likely concern for keeping his subjects' physical and financial resources at home and keeping their political (rather than religious) aspirations focused on defending Morocco's autonomy. Finally, travel involved a risk of defection, spying, or capture, especially as the route to Mecca led through territory more treacherous than ever.

It was not difficult for al-Ṣiqilli to produce a fatwā supportive of al-Ḥasan's desired restrictions, given the rich tradition of Mālikī legal arguments against going on hajj, as well as Bello's recent effort to catalogue those arguments. AlMāzarì's high bar for "ability," al-Ṭurțūshì's blanket prohibition of the hajj for Maghribīs, and al-Burzulì's demonic-beings story come together in a compelling and memorable narrative. Al-Ṣiqillì's failure to mention disease makes as much sense from the perspective of legal argument as from a political perspective. Not only were Māliki jurists conflicted over the phenomenon of contagion, but also the portrayal of Mecca as an epicenter of death and disease likely would have met with public resistance and would have exacerbated the discomfort many jurists must have felt in using the tools of their trade to undermine a central pillar of Islam. ${ }^{90}$ Al-Ṣiqilli's text locates the dangers and problems to be faced by potential pilgrims in the journey itself, not the destination, which, of course, remained the direction of prayer.

\section{Conclusion: Politics and Fiction in Mālikī Fatwās}

Often associated with intensely personal religious experiences, pilgrimage also has powerful political implications. The discovery of saints' tombs has often brought economic and political power to those who control the site, guarantees of safe conduct for pilgrims have featured prominently in foreign diplomatic negotiations, inter-religious warfare has often featured the capture or destruction of pilgrimage sites, and individuals have used pilgrimages to gain stature or escape service. British anthropologist Victor Turner recognized the political significance of pilgrimage, considering the subversive potential of communitas, his term for the radical sense of unity and equality fostered by the experience. ${ }^{91}$ Released from the social structures constraining everyday life

\footnotetext{
9o On contagion in Islamic legal thought, see Justin Stearns, Infectious Ideas: Contagion in Premodern Islamic and Christian Thought in the Western Mediterranean (Baltimore: Johns Hopkins, 2011).

$91 \quad$ See Victor Turner, "Pilgrimage and Communitas, Studia Missionalia, 23 (1974): 305-27;
} 
and compelled by a spontaneous sense of common humanity and free choice, pilgrims may decide to challenge the structured roles and hierarchies they have temporarily transcended. More recently, Turner's concept of communitas has been usefully challenged by John Eade and Michael Sallnow's model of pilgrimage centers as sites of contestation and sharpened group boundaries. ${ }^{92}$ The political nature of pilgrimage is equally apparent in this newer model of competition over symbolic meanings and sacred resources.

Neither theory fully accounts for the Mālikī discouragement of the pilgrimage, which focuses almost entirely on the journey to Mecca rather than the destination. Yet both models offer limited insights as to why the pilgrimage to Mecca might have been perceived as a threat to the security and stability of political regimes in the Islamic West: The shared sense of belonging, devotion, and duty to visit Mecca drained resources from Iberia and the Maghrib, while exposing pilgrims to competing ideas and prospective loyalties. ${ }^{93}$

If pilgrimage is a political act, so too is its prohibition. The jurists studied here were tasked with preventing defection, "draft-dodging," disease, and the loss of human and financial resources, not missed prayers. They did so in the medium at their disposal: a rich legal tradition that simultaneously spoke with the authority of "universal" Islam while subverting one of its core tenets in order to adapt to local conditions in the Islamic West. I call the discrepancy between the jurists' stated and actual reasons for discouraging the hajj "dissemblance," the first of two "fictional" elements characteristic of most of the fatwās studies here.

A primary objective of this study has been to highlight the non-transparency of Islamic legal literature. All legal genres are constrained by specific con-

Victor Turner and Edith Turner, Image and Pilgrimage in Christian Culture (New York: Columbia University Press, 1978), esp. Ch. 1, "Pilgrimage as a Liminoid Phenomenon," 1-39.

92 John Eade and Michael J. Sallnow, "Introduction," in Contesting the Sacred: The Anthropology of Christian Pilgrimage, eds. Eade and Sallnow (London: Routledge, 1991), 1-29.

93 Exposure to dangerous political ideas and organizations while in Mecca remains a concern of Muslim nation-states. In April 2014, Tajikistan announced a ban on the hajj for citizens below the age of 35 years. The ban ostensibly aimed to give older Muslims a chance to perform the pilgrimage, as Tajikistan may send only a limited number of pilgrims to Mecca annually (each country has a fixed quota). Critics suggest that the move is actually an attempt to prevent young Tajiks from being recruited into extremist groups such as ISIL, the Islamic State of Iraq and the Levant. World Press News Desk, "Tajikistan Bans Hajj Pilgrimage for Young Muslims," World Bulletin 14 April 2015, <http://www.world bulletin.net/news/157855/tajikistan-bans-hajj-pilgrimage-for-young-muslims>. 
ventional parameters and motivated by particular imperatives. I suggest that fatwās specifically are shaped by at least five constraints:

- Legal: Arguments must be expressed according to the existing framework of the law. For example, in the contemporary United States, legal arguments against abortion must center on "personhood," not on the interpretation of biblical verses. The motivations and texts that best explain the reasoning of activists are thus elided, necessarily, from their associated legal discourse. In the case of Islamic legal texts, the principal is similar - but here, a legally legitimate argument is one that is ultimately grounded in a given school's interpretation of the Qurān and Hadìth. As the cases of dissemblance reviewed here demonstrate, political rationales (such as the prevention of cholera or defection) must be expressed and justified in religious legal terms (such as the obligation to pray).

- Political: Legal opinions are responsive to prevailing political circumstances. State officials pose questions, lay Muslims question policies, and political events create new situations that require fresh opinions. Jurists usually express politically sensitive opinions obliquely and cautiously, to avoid overt critique and to make their opinions applicable to general cases rather than to single occurrences.

- Generic: Manuals on fatwā-giving prescribe specific conventions that should be followed within this genre. ${ }^{94}$ The response must not stray too far from the mandate of the question, and the responding jurist may not question the facts provided in the question. Jurists also frame responses differently for professional or lay audiences - fellow jurists should be offered the proof texts and legal reasoning for a position, including any points of disagreement or ambiguity. Lay Muslims should be presented with a clear and concise answer to the question.

- Professional: Professional etiquette encourages muftīs and jurists to veil their critique of living jurists and political authorities. ${ }^{95} \mathrm{~A}$ few literary conventions regularly employed by jurists also shaped legal discourse, such as the use of three-part or five-part typologies, e.g., Ibn 'Abbād's division of the pilgrimage into wholly blameworthy, partly blameworthy, and wholly praiseworthy categories.

94 See Muhammad Khalid Masud, Brinkley Messick, and David S. Powers, "Muftis, Fatwas, and Islamic Legal Interpretation," in Masud, Messick, and Powers, Islamic Legal Interpretation, 3-32.

95 On the reluctance of jurists to critique their peers openly while they are still living, see Stewart, "Polemics and Patronage." 
- Material: For written fatwās delivered by a jurist directly to a mustaftī, material considerations helped shape the response. In his manual on istiftā', Shihāb al-Dīn al-Qarāfì (d. 684/1285) advised muftìs not to leave any blank spaces large enough to be filled in by someone wishing to alter the opinion. ${ }^{96}$

In addition to these constraints, many of the fatwās examined here are motivated by a need to disseminate broadly, in readily understandable terms, a legal position that would be translated into enforceable state policy. This imperative fostered the crafting of imaginative stories, such as that of the eastern and western demonic beings that constitute a second class of "fictional" elements in these texts. While these stories may originate in sermons or study circles, they are also a common feature of formal, written legal discourse. Indeed, the Pact of 'Umar, for example, adopts a literary form designed to convey a strategically crafted story regarding the text's genesis. As Mark Cohen has argued, the document's conditions for dhimmi subjection to Muslim rule are cast in the form of a petition composed by Christians themselves to the caliph 'Umar b. al-Khațtāb (r. 634-44), while a non-prophetic hadìth provides the formal prologue and conclusion, confirming 'Umar's putative receipt and acceptance of the petition. ${ }^{97}$ According to Cohen, placing responsibility for the Pact's contents on a Christian community would have promoted enforcement as well as avoided the question of the stipulations' validity according to Qurānic law.

Together, these constraints and imperatives have a profound impact on the form and content of complex Islamic legal opinions, especially those that respond to politically sensitive matters of public policy. Occasionally, jurists were so constrained by their circumstances - here, the need to produce an opinion discouraging the hajj that employed legally valid arguments, masked the political motives for the opinion, and compelled the lay public - that they voiced their discomfort with their own fatwās or those of their peers. After issuing his fatwās declaring the hajj sinful for all Andalusīs (and subsequently Maghribīs), Ibn Rushd presumably retreated from the implication that alAndalus is exceptional with regard to the basic tenets of Islam. Like al-Māzarī and Aḥmad Zarrūq, Ibn Rushd acknowledged that blanket pronouncements

96 Sherman Jackson, "The Second Education of the Muftī: Notes on Shihāb al-Dīn al-Qarāfìs Tips to the Jurisconsult," The Muslim World 82: 3-4 (1992): 11-12.

97

There is a rich scholarly literature on the Pact of 'Umar. Here I follow Mark Cohen, "What Was the Pact of 'Umar? A Literary-Historical Study," Jerusalem Studies in Arabic and Islam 23 (1999): 100-57. 
regarding exemption from the hajj deviate from the ideal language that jurists might use in conversation with one another, unencumbered by the needs of local rulers or the limitations of the public. As scholars, we are not generally privy to such internal quibbles regarding the proper way to express particular, shared opinions on matters of general concern. Yet these critiques, along with the clear cases of politically motivated dissemblance found in this series of texts, provide valuable evidence that we must learn to read between the lines on multiple levels in an effort to understand legal texts.

The question remains: Why did this tradition of discouraging or prohibiting the hajj arise in the Mālikī school? A few studies of Maghribī and Andalusī travel literature provide some promising insights. In his analysis of Moroccan travelogues composed between the fourteenth and seventeenth centuries $\mathrm{CE}$, Abderrahmane El Moudden concludes that rihla (travel) literature is ambivalent. ${ }^{98}$ While travel connects the author and his audience to the wider Muslim world in meaningful ways, it also fosters a sense of local consciousness, identifying and celebrating what is distinctive about Moroccan society. InJourneys to the Other Shore, a comparative study of Western and Muslim travelogues, Roxanne Euben advances a similar argument regarding travel literature in general: While travel is associated with the pursuit of knowledge, the knowledge produced is comparative in nature, refining understandings of self and other, familiar and foreign, through articulation of such "nested polarities" as West and East, or Muslim and Christian. ${ }^{99}$ She cautions that exposure to the unfamiliar can foster antagonism and increase "provincial solidarities" rather than encouraging openness or identification, as may be expected. ${ }^{100}$

Amira Bennison's comparison of Maghribī Muslim and Iberian Christian responses to the shifting frontiers of the Reconquest resonates with both El Moudden's and Euben's assessments. Bennison argues that from the twelfth century, "existence on the periphery paradoxically engendered an internal perception of religio-cultural centrality among both Iberian Christians and Moroccan Muslims." ${ }^{101}$ Faced with devastating territorial losses and social instability, Maghribī Muslims asserted their "orthodoxy" and differentiated

98 Abderrahmane El Moudden, "The Ambivalence of Rihla: Community Integration and Self-Definition in Moroccan Travel Accounts, 1300-1800," in Muslim Travellers: Pilgrimage, Migration, and the Religious Imagination, ed. Dale Eickelman and James Piscatori (Berkeley: University of California Press, 1990), 69-84.

99 Roxanne Euben, Journeys to the Other Shore: Muslim and Western Travelers in Search of Knowledge (Princeton: Princeton University Press, 2006), esp. 8-10, 15-16.

100 Euben, Journeys, 18.

101 Amira K. Bennison, "Liminal States: Morocco and the Iberian Frontier between the Twelfth and Nineteenth Centuries," in North Africa, Islam, and the Mediterranean World: 
themselves not only from Christian Others but also from Mudéjars (Muslims under Christian rule) and from eastern Muslims. Travel literature, in particular, "cultivated most assiduously by western Muslims," served to assert Morocco's importance in the struggle to preserve Islamic territorial and religious integrity. ${ }^{102}$ Bennison notes a paradox: that Andalusian-born Ibn Jubayr's travels eastward, for example, support a vision of the East as the fountain of religious knowledge while simultaneously denigrating the corrupt practices of Meccan Muslims. ${ }^{103}$

The ambivalence of Ibn Jubayr's influential twelfth-century rihla is mirrored, I argue, by the series of legal opinions prohibiting the pilgrimage that began to be issued in this same period. Mālikī jurists refrained from denigrating Mecca or Meccan Islam, but they freely stirred up the imaginations of their audiences about the dangers and corruptions lying in wait on all paths leading east. They asserted the religio-cultural centrality of the Islamic West by assuring Andalusī and Maghribī Muslims greater merit for the actions they could best perform at home, from jihād to the meticulous performance of their daily prayers. Yet these jurists simultaneously upheld the hajj as a universal Islamic obligation, and Mecca as an object of worthy, even obligatory, desire.

This distinctively Mālikì discourse discouraging or prohibiting the hajj may initially have reflected the risks of travelling long distances across inhospitable lands to reach the central Islamic lands from the western periphery. By the time of Ibn Rushd's fatwa in the twelfth century, these early precedents were adapted to meet the practical and ideological needs of states on the Christian-Muslim frontier by prioritizing local political interests and furthering a regionally specific understanding of normative Islamic requirements. ${ }^{104}$ This tradition proved both long-lasting and versatile, moving from physical to economic jihâd, from the Christian to the pagan frontier, and into the colonial

From the Almoravids to the Algerian War, ed. Julia Clancy Smith (London: Frank Cass, 2001), 20.

Bennison, "Liminal," 18.

103 Bennison, "Liminal," 18.

104 I am not arguing that all or most Mālikī jurists endorsed this regionally specific understanding of the hajj, but that the opinions discussed here represent a significant and distinctive, if non-dominant, discourse within the school. While we should assume that the default Mālikī position over the eight centuries treated here was not to discourage the pilgrimage, this series of opinions nonetheless constituted an evolving tradition - a resource or set of precedents upon which each later jurist could draw - rather than a set of unrelated, deviant opinions without grounding in the school's legal heritage. 
period. ${ }^{105}$ Muslims from the Islamic West continued to go on hajj, of course, but, paradoxically, many did so against the dictates of "juridical Islam."

\section{Appendix A: Two Fatwās by Abū al-Ḥasan al-Lakhmī (d. 478/1086) - Commentary by Abū al-Q̣āsim al-Burzulī $(\text { d. } 842 / 1438)^{106}$}

\section{First Question}

Al-Lakhmì was asked about a man who wanted to set forth on the pilgrimage to Mecca (the hajj). The overland route was impossible at the time, so he intended to travel by sea, but feared sailing as well. He was told: "[Sailing] generally entails risk, ${ }^{107}$ fear of the Christians ( $a l-R \bar{u} m)$, and exposure to that which you should guard against aboard the ships. You are excused from [travelling by] that [route]."

In your opinion, is travelling by sea permitted, despite what is feared? In these times, must a man hasten to undertake the hajj, or should he delay because of the

105 Vestiges of this Mālikī tradition of fatwās that discourage the pilgrimage extended into post-colonial Tunisia. In 1958, two years after Tunisia gained independence from France, the state muftī, Muhammad al-Azīz al-Jacayyaț (1886-1970) was asked, presumably by a government official, if the state might solicit from its citizens the funds that they were planning to use on the pilgrimage, and to channel that money instead to building up the national defenses of the new state. The mufti agreed that if given voluntarily, and considering the state's urgent security needs, this would be acceptable. He noted, however, that the prioritization of one obligation - jih $\bar{a} d$ in this case - over another, the pilgrimage - should occur only when there is a true conflict of obligations. Al-Jacayyat saw no real conflict between money earmarked for the hajj and money spent in support of jihäd as long as money was still being spent on non-obligatory travels and entertainment. A fiscally responsible, pious Muslim should thus prioritize both the hajj and jihād over other modern-day distractions. Muhammad Būzghība, ed., Fatāwā Shaykh al-Islām fì Tūnis Muhammad al-'Azīz Ja'ayyaț wa-ijtihādātihi wa-tarjịḥātihi (Beirut: Dār Ibn Ḥazm, 2005), $78-80$.

106 I have translated these two fatwās (1:593) and al-Burzulī's commentary (1:593-5) as they appear in al-Burzulī, Jāmi masāil al-ậā̄m (1:593-5). For al-Lakhmī's two fatwās, I have also consulted al-Wansharīsì's al-Mi'yār (1:434-5) and Ḥamīd Lahmar's edition of al-Lakhmī's opinions (al-Lakhmī, Fatāwā, 62-63). Hassan Khalilieh has previously offered a summary English translation of this fatwā as well as those of al-Māzarī and Ibn Rushd, based on the versions in al-Wansharīsī only. My translations differ substantially from those of Khalilieh. See Khalilieh, "Legal Opinion," 62-65.

107 Al-Burzulī and al-Lakhmī read ḍarar, "harm," while al-Wansharīsī reads gharar, "risk." 
brigands along the route? ${ }^{108}$ If he delays and ${ }^{109}$ dies prior to performing the pilgrimage, is he a sinner, considering that he is prepared, with nothing preventing him [from going] other than fear of the overland route, and the risk ${ }^{110}$ of travelling by sea? We were told that one of the early master jurists held that the obligation to perform the pilgrimage has lapsed. ${ }^{111}$ Clarify for us your opinion on this.

\section{Answer}

He answered: The route today from Alexandria ${ }^{112}$ to Mecca, in its [present] condition, is such that one is not bound by the obligation to perform the pilgrimage. Whoever delays under these conditions does not $\sin$ [by doing so].

\section{Second Question}

He was also asked about a man who set forth on the pilgrimage by a route feared to be risky, and who probably would not arrive safely. Is he among those who cast themselves into destruction? ${ }^{113}$ Or is he rewarded for striving to perform the obligatory pilgrimage? Or, if he has already performed the obligatory pilgrimage, [is he rewarded] for seeking closeness to God - may He be exalted - by performing a supererogatory pilgrimage? Or is he neither rewarded nor a sinner?

\section{Answer}

He answered: The obligation to perform the pilgrimage lapses with this degree of risk. ${ }^{114}$ If he imposes this [difficult undertaking] upon himself after this [assessment], he will not be free of sin.

108 In al-Burzulī and al-Lakhmī the text reads "li-aḥwāl inqițā'al-țuruq," meaning a disruption or blockage of the routes, whereas al-Wansharīsì reads "li-aḥwāl al-qutțác fi al-țarīq," specifying highway robbers. Attacks by armed groups is the more likely meaning here.

109 In al-Burzulī and al-Lakhmī the text reads "or dies," but a delay leading to death makes more sense here. Most Western Mālikī jurists (but not the Baghdadī branch of the school) agreed that delaying the pilgrimage is acceptable, so long as one does not fear losing the ability to perform the hajj. The minority opinion is that a Muslim is obligated to perform the pilgrimage as soon as he is able to do so.

110 Al-Burzulī and al-Lakhmī read "harm" (darar) rather than "risk" (gharar).

111 In al-Wansharīisi the text continues, "and that one who delays [its performance] under these conditions does not sin." This continuation in the question is likely a mistake, as this same text appears in al-Lakhmì's answer in the form of a statement.

112 Al-Wansharīsī adds "and beyond."

113 This is a reference to the first portion of Quraan 2:195: "Spend your wealth for the cause of Allah, and be not cast by your own hands to ruin" (M. Pickthall translation).

114 In al-Burzulī and al-Lakhmī the text reads darar, "harm," rather than gharar, "risk." 


\section{Commentary by al-Burzulī}

I [viz., al-Burzulī] said: This [principle] is clear according to what Ibn Rushd has articulated, which is that seeking to change the reprehensible actions [of others] is conditional upon not fearing for oneself. ${ }^{115}$ As for [the opinion] chosen by 'Izz al-Dīn, ${ }^{116}$ [forbidding what is wrong] is permissible even if one fears for oneself. Yet, often we have observed this [viz., critique of wrongdoing] done without harm. The prescribed action is determined according to the most probable [outcome]. ${ }^{117}$

Thus, [the pilgrim's setting forth] is likewise [evaluated according to the probable outcome], if his intention is sound - that is, if it is known that he performs the obligatory and supplementary prayers. ${ }^{118}$ If he perceives in himself an inability to [perform] them, al-Māzarì's opinion that he should not perform the pilgrimage has already been presented. ${ }^{119}$

Our shaykh, the master jurist Abū Muḥammad al-Shabībī120 - may God have mercy upon him - used to issue fatwās based on this [position]. He had travelled the [pilgrimage] route, and said: "What motivates people to go on the pilgrimage in this day

115 This passage refers to the moral obligation of Muslims to "command the good and forbid the wrong," al-amr bil-ma'ruf wa'l-nahy 'an al-munkar. On this principle, see Michael Cook, Commanding Right and Forbidding Wrong in Islamic Thought (Cambridge: Cambridge University Press, 200o). Cook treats the views of the Córdoban jurist Ibn Rushd al-Jadd ("the Grandfather," d. 520/1126) in chapter 14, "The Mālikīs" (pp. 357-92).

116 'Izz al-Dīn b. 'Abd al-Salām al-Sulamī (d. 66o/1262) was a Shāfi'ī jurist known for his willingness to criticize wrongdoing in public. His opposition to the Ayyūbid ruler al-Ṣālị̣ Ismāîl resulted in al-Sulamī's imprisonment and subsequent move from Damascus to Egypt. On the differences between al-Sulamì's position and that of Ibn Rushd, see Cook, Commanding, 369-70; on al-Sulamī, see $E I^{2}$, s.v. "al-Sulamī" (E. Chaumont).

117 It is unclear whether the preceding two sentences relate to forbidding the wrong, performing the pilgrimage, or - most likely - a general category of meritorious actions for which one's safety is a condition for permissibility, advisability, or obligation. Al-Burzulī's point appears to be that, prior to acting, a determination should be made regarding the probability of performing the act in question safely. This probability must then be considered in determining the legal status of the act in a given context.

118 Farāì al asalät wa-tawābicuhā, the five obligatory daily prayers, along with additional prayers that are considered voluntary (nawäfil) but are routinely performed in conjunction with the obligatory prayers and at other times during the day.

119 Abū 'Abd Allāh Muhammad al-Māzarī (d. 536/1141), a Tunisian Mālikī jurist. The fatwās referred to here are included in al-Burzulī, 1:586-7; al-Wansharīsī, 1:433-4; and al-Māzarī, Fatāwā al-Māzarī, 113-4. Following his commentary on al-Lakhmī's fatwās, al-Burzulī includes another fatwā in which al-Māzarī prohibits travel to Sicily for the purpose of trade if Muslims will be subject to Christian law there. This fatwa is translated and analyzed in Hendrickson, "Is al-Andalus Different?".

120 Abū Muhammad 'Abd Allāh b. Yūsuf al-Balawī al-Shabībī (d. 782/1380), a Mālikī jurist from Qayrawān. On him, see al-Burzulī, Jāmi‘ masāil al-aḥkām, 1:9-10; Makhlūf, Shajarat al-nūr, 1:324. 
and age is merely selfish desire." This is his description of the actions of the majority of laypeople, [who are] not motivated by a true intention [to perform the pilgrimage] for God - may He be exalted. Thus you see those who, from the moment they set forth, commit sins such as insulting others, engaging in forbidden acts, abandoning prayer, making false accusations of adultery, gossiping, and failing to adhere to the bounds set by God - may He be exalted. To this may be added ignorance of many of the rules guiding aspects of the pilgrimage. Thus you see those who will probably be [counted as] sinful, rather than rewarded, for their pilgrimage. This [sin] results from the deficiencies in many of their religious affairs that arise from this [insincere pilgrimage].

A student from the Maghrib related to him [viz., al-Shabībī] a story in my presence. He said:

The demonic beings of the East and of the West argued over which of them is greater in leading [men] astray. The demonic beings of the East said to the demonic beings of the West: "We are stronger than you, because we incite men to acts of disobedience and the violation of prohibitions at the sacred sites of the prophets - may prayers and peace be upon them." Then the demonic beings of the West said: "We are more powerful than you in leading [men] astray, because we find a man who is with his family and children, and he is performing the required prayers, almsgiving, and other duties; and he is at ease, and his angels are likewise [at ease] with him because of the paucity of misdeeds [to be recorded against him]. But when a poet's recitation inspires longing for the land of the Hijāz, we urge him on with a knife and prompt him to set forth, and then he sets forth. Then from the day of his departure, we prompt him to abandon his required duties and to commit prohibited acts. From the day of his departure until the day of his return to his family, he suffers loss in his person, his wealth, and his religion, in the eastern and western parts of the earth." Therefore the demonic beings of the East conceded [to the demonic beings of the West] that they held the [greater] power to lead [men] astray.

I [viz., al-Burzulī] said: There is no doubt that I witnessed some of this, or more than this, during my pilgrimage travel. If the situation is thus, then the fulfillment of one religious obligation that brings about the neglect of many obligations is inappropriate. [A pilgrim should not set forth] until he is inwardly convinced that he will fulfill [all] those obligations of which he is capable, or, that during travel he will [maintain] the same status [with regard to religious obligations] as at home.

Regarding what al-Lakhmī has pointed out regarding travel by sea, there is a current issue, namely, that it has become the custom among us today to travel by sea aboard Christian ships. [The Christians] rent them to Muslims from Ifrīqiyā to Alexandria. Often the Christians have power and mastery over the Muslims until they arrive. Sailing from Alexandria toward the lands of the Maghrib is similar; the Christians likewise 
occasionally engage in transgressions. Our shaykh the master jurist [viz., al-Shabībī (d. $782 / 1380)]^{121}$ used to say that this is analogous to travelling to enemy territory (ard al-harb) for the purpose of trade. He noted that the early jurists (al-mutaqaddimin $)^{122}$ held this [travel] to be strongly reprehensible, and [they discussed whether] or not it impugns one's legal credibility.

[Al-Shabībì] said: "The correct opinion today is that it [viz., the permissibility of travel on Christian ships] depends on the conditions (khilāffi hăal). If the ruler of Tunis is strong, such that the Christians would fear him if they were to engage in treachery or sour relations [with Muslims], then this is not a serious matter; and if not, then it is dangerous." In another exposition, he said: "The correct opinion is that it is dangerous." But I [viz., al-Burzulī] witnessed a man of virtue and knowledge travelling with them [viz., the Christians], and he was of the opinion that necessity permitted this [travel by sea] to him, because of the impossibility of the overland route.

I said: This [opinion] was [also] attributed to al-Qabbāb ${ }^{123}$ - one of the jurists of Fez - and to Ibn Idrīs ${ }^{124}$ - one of the jurists of Bijāya, and ${ }^{125}$ it was well known that they were men of religion and knowledge. In my opinion, this is a case of two opposing evils (taqābul al-dararayn), in which the lesser removes the greater, as [Muhammad] - may prayers and peace be upon him - indicated. So one should weigh the corruptions that will result from his going to sea against the benefits he will attain in this world or the next. Whenever the reprehensible [element] is great, it should be considered, and when it is insignificant, it [may be] dismissed.

\section{Appendix B: Fatwāa by Abū 'Abd Allāh Muḥammad al-Māzarī (d. 536/1141) ${ }^{126}$ - Commentary by Abū al-Q̄āsim al-Burzulī (d. 842/1438) and Aḥmad b. Saīi al-Mujīlidī (d. 1094/1683)}

\section{Question}

Al-Māzarī was asked about [the opinion that] the obligation to perform the pilgrimage is in abeyance in this age.

121 Al-Burzulī uses the same phrase here (shaykhunā al-imām al-faqīh) that he uses to introduce al-Shabībī above.

122 Mālikīs consider Ibn Abī Zayd al-Qayrawānī (d. 386/996) to be the first of the "later jurists."

123 Aḥmad b. al-Qāsim al-Qabbāb (d. 778-9/1376-7). Makhlūf, Shajarat al-nūr, 1:338.

124 Aḥmad b. Idrīs al-Bijā̄ī (d. 760/1358). Makhlūf, Shajarat al-nūr, 1: 335 .

125 The text reads wa-lakin, "but." I have chosen to read this as wa-kana, "and it was ..." in order to preserve the sense of the passage. It is also possible that something is missing from the text.

126 My translation is based primarily on al-Burzulī (Jāmi' masāil al-ahkām, 1:586-7) and secondarily on al-Wansharīsī (al-Mi'yār, 1:433-4), with occasional recourse to the lithograph 


\section{Answer}

He answered: The answer to this question is obvious. A knowledgeable scholar ${ }^{127}$ must not generalize about this [matter]. It is obvious that the obligation to perform the pilgrimage $^{128}$ does not lapse when the [necessary] means are found, and [the pilgrim] does not fear for himself or for his property and does not fear that he will be led astray in his religion, commit prohibited acts, or abandon [his] prayers or other obligations.

If he fears that he will perish, or that he will attain this [goal of fulfilling the pilgrimage] only by giving much of his money to oppressors along the route, and this loss will reduce him to poverty or cause him severe hardship, then, in this case, the obligation to perform the pilgrimage lapses, according to what our fellow [Mālikī jurists] have stipulated.

Likewise, if he begins to neglect his prayers by [performing] them outside of their appointed times, or by performing a different [prayer] during a [given prayer's] time, and only pilgrimage travel has placed him in this situation, then this travel is not permissible, and the obligation to perform the pilgrimage has lapsed for him.

If [the problem] is only that he will see and hear prohibited acts, this [case] encompasses a wide range [of specific situations], and he [viz., the mufti] must discern the specific nature of the prohibited act as well as the method for escaping it. ${ }^{129}$ Discussion of this [matter] in general terms is inappropriate, because that does not allow for a detailed exposition. ${ }^{130}$

edition of the Mi'yār (al-Wansharīsī, al-Mi'yār al-mu'rib wa'l-jāmi' al-mughrib 'an fatāwì ahl Ifrīqiyā wa'-Andalus wa'-Maghrib, ed. Ibn al-'Abbās al-Bū-'Azzāwī, et al., 12 vols. (Fez, 1897-98), 1:342. Unless otherwise noted, all references to al-Wansharīsī are to the Rabat edition. Al-Tāhir al-Ma'mūrìs edition of this fatwā (al-Māzarī, Fatāwā, 113-14) is also based on these two sources (al-Burzulī and the Rabat edition of al-Wansharīsī), without annotation. Only significant differences between al-Burzulī and al-Wansharīsī will be noted.

127 Al-muḥașșil, one who has acquired knowledge.

128 Al-Wansharīīi reads "pilgrim" instead of "pilgrimage," requiring an active reading of the subsequent verbs ("what is obvious is that the pilgrim, when he finds the means, and does not fear for himself ..."). This construction is less compatible with the overall syntax of the sentence, and is one of several typographical errors in the Rabat edition of this passage. The lithograph edition reads "pilgrimage."

129 It is possible that al-Māzarī is referring to the pilgrim's need to recognize and avoid prohibited acts. Given the context, however, the more likely meaning is that the muftit, before issuing an opinion as to whether or not a given petitioner is obligated to perform the pilgrimage, must consider the specific vices that the pilgrim is likely to encounter, and his capacity for staying out of trouble.

130 Instead of "idh lā yumkin al-taf̣̂ill," al-Wansharīsī reads "idh yumkin al-taf̣̣ill," likely a combination of editing and typographical errors. 
This is what is certain with regard to this issue.

\section{Al-Māzarìs Retrospective Commentary ${ }^{131}$}

Those present conferred and debated the issue, speaking at length and disputing intensely. One discussant opined that the obligation to perform the pilgrimage has lapsed, while another spoke of its [continuing] obligation; others were undecided. Then suddenly at the back of the crowd [appeared] the preacher Abū al-Tayyib - may God have mercy on him; we had not seen him. He thrust his head into the circle and said, addressing the shaykh:

Oh my Master,

If shedding my blood was your utmost desire,

Your vision would not extend beyond shedding my blood."

Al-Lakhmī thought well of this clever remark from the viewpoint of the Suufì path rather than from that of the law. But the correct position on this matter is the one we have previously presented.

\section{Commentary by al-Burzuli}

I [viz., al-Burzulī] said: The story about al-Lu'lu'ī is similar to this story [viz., about Abū al-Tayyib]. He put four thousand [coins] in his bag and went on the pilgrimage by foot. Al-Jawzī mentions this famous story in al-Mawrid al-'Adhb (The Sweet Spring).

On the whole, ${ }^{132}$ one who downplays his own desires in seeking to please God and to leave behind the world and its ornaments, and to imagine what will transpire for

131 The following section, present in both al-Burzulī and al-Wansharīsī, appears to be al-Māzarì's retrospective narrative of an oral debate in which he and his teacher al-Lakhmī both participated. This structure parallels al-Māzarī's fatwā on the permissibility of travel to Sicily for the purpose of trade. In that fatwāa al-Māzarī relays his legal opinion by narrating a story about an event decades earlier, during which he had presented that opinion in the course of an oral debate amongst the leading jurists of his time. In this pilgrimage case, the fatwa attributed to al-Mazari may have been his own contribution to this oral discussion, or may be a position that he came to as a result of that event. Al-Lakhmïs role in validating the preacher's comment suggests that the setting is a study circle led by al-Lakhmī. Two additional versions of this story, including one attributed explicitly to al-Māzarī, appear in al-Ṣiqillī’s fatwā in Appendix D. On al-Māzarī’s fatwā on trade, see Hendrickson, "Is al-Andalus Different?".

132 Al-Wansharīsī includes the following two paragraphs, from "on the whole" to "Amen," but omits the preceding paragraph regarding al-Lu'lu'ì. Al-Wansharīsī replaces "I said" with "it is said" to introduce this section, without acknowledging al-Burzūlī as his source. 
him in the presence of God and in the balance of His mercy and His beneficence, [such a person] will pay no heed to the condition in which he arrives [in Mecca]. Those with a faculty for perception sense this and understand it.

By God, I ask that He apportion to me a part of that abundant share which delights us and gives pleasure to whoever obeys God - may He be exalted. His forgiveness is great, through His grace and benevolence. Amen.

\section{Footnote in al-Wansharīsī: Commentary by Aḥmad b. Sa'id al-Mujïlidīi33}

In the margin of the lithograph edition:

Praise be to God.

In the abridgment of this work, immediately after this reply, appears the following:

I said: I have seen in the Manāsik (pilgrimage guide) of Sīdī Yūsuf al-Fāsī, or one of his brothers, that this expression, i.e. his saying "the obligation to perform the pilgrimage lapses," shows a lack of discipline. This is because [in speaking of] the obligations imposed by God, one cannot say that they have lapsed. Abrogation occurred only in the time of the Prophet, may God bless him and grant him peace.

Or words to that effect.

133 The editors of the Rabat edition of the Micyār have inserted this note directly after "Amen," above (1:434). They are copying the text of a note left by the editors of the lithograph edition of the Míyār (1:342), who, in turn, are reproducing a note they most likely found in Ikhtiṣār al-Míyār, a one-volume abridgment of the Míyār by Aḥmad b. Sa'īd al-Mujīlidī (d. 1094/1683), extant only in manuscript. On al-Mujīlidī, see Muhammad b. Jafar al-Kattānī (d. ca. 1346/1927), Salwat al-anfās wa muḥādathat al-akyās bi man uqbira min al-'ulamā' wa'l-ṣulaḥā' bi Fās, 3 vols., ed. 'Abd Allāh al-Kāmil al-Kattānī, et al. (Casablanca: Dār al-Thaqāfa, 2004), 3:253, and 'Umar Riḍā Kaḥhāla, Mu'jam al-mu'allifinn, 4 vols. (Beirut: Mu'assasat al-Risāla, 1993), 1:146. On the editorship of the Rabat and lithograph editions of the Mi'yār, see Francisco Vidal Castro, "El Mi'yār de al-Wanšarīsī (m. 914/1508). I: Fuentes, manuscritos, ediciones, traducciones," Miscelánea de Estudios Árabes y Hebráicos 42-43.1 (1993-1994): 317-61. On abridgments of the text, see al-Wansharīsī, al-Mi yār, 1:ță’ (front matter of the Rabat edition). 


\section{Continuation in al-Burzūlì ${ }^{134}$}

In his Aḥkām, Ibn al-Ḥājj [d. 529/1134] ${ }^{135}$ [relates that] Abū 'Imrān [d. 430/1039] ${ }^{136}$ and Ibn 'Abd al-Rahmmān [d. 432/1041] ${ }^{137}$ issued fatwās to the effect that the obligation to perform the pilgrimage had long since ceased to be in effect for the people of al-Andalus. When the two of them had encountered [...] enroute, he [viz., an unnamed pilgrim] said, "it is usually safe."138 That was in the year 19 [419/1028-29]. ${ }^{139}$

A similar [opinion] is attributed to 'Abd al-Haqq. ${ }^{140}$

134 Al-Burzulī, Fatāwā al-Burzulī, 1:587-88. Al-Wansharīsī places these opinions, clearly adapted from al-Burzulī, after Ibn Rushd's fatwā. Al-Wansharīsī, al-Mi'yār, 1:433.

135 Muḥammad b. Aḥmad al-Tujībī, known as Ibn al-Ḥājj (d. 529/1134), served as chief judge of Córdoba on two occasions under the Almoravid amir 'Alī b. Yūsuf b. Tāshufinn. Contemporary biographer Ibn Bashkuwāl notes that Ibn al-Hājj's opinions guided the fatwās of his day and that he was highly respected, but he was murdered during Friday prayers at the Great Mosque of Córdoba. See Khalaf b. 'Abd al-Mālik b. Bashkuwāl (d. 578/1183), al-Șila, 2 vols. (first 2 vols. of publisher's 6-vol. set including al-Takmila li-Kitāb al-Șila and Șilat al-Ṣila), ed. Jalāl al-Asyūṭī (Beirut: Dār al-Kutub al-'Ilmīya, 2008), 2:195-6 (no. 1288); Makhlūf, Shajarat al-nūr, 1:193-4; Rachid El Hour, "Biografías de Cadíes en Época Almorávide: Análisis de las Fuentes Árabes," in Biografías y Género Biográfico en el Ocidente Islámico, ed. María Luisa Ávila and Manuela Marín, Estudios Onomástico-Biográficos de Al-Andalus, viII (Madrid: Consejo Superior de Investigaciones Científicas, 1997), 177-99. The work mentioned by al-Burzulī, extant only in manuscript, is Nawāzil al-Ahkām, also known as al-Fuṣül al-muqtadaba min al-ahkām al-muntakhaba (Short Chapters on Selected Judgments). See Jazā’ al-Ḥarb, "Namādhij," 341.

136 Abū 'Imrān Mūsā b. 'Īsā al-Fāsī (d. 430/1039) was born in Fez but settled in Qayrawān, from where he journeyed west to Córdoba as well as east to Baghdad and Mecca. He performed the pilgrimage several times. On both Abū 'Imrān and Ibn 'Abd al-Raḥmān (mentioned next), see Hady Roger Idris, "Deux maitres de l'école juridique kairouanaise sous les Zīrīdes (XI ${ }^{\mathrm{e}}$ siècle): Abū Bakr b. 'Abd al-Raḥman et Abū 'Imrān al-Fāsī," Annales de L'Institut d'Études Orientales d'Alger 13 (1955): 30-60.

137 Abū Bakr Aḥmad b. 'Abd al-Raḥmān al-Khūlānī al-Qayrawānī (d. 432/1041), a contemporary and peer of Abū 'Imrān al-Fāsī. On both jurists, see Idris, "Deux maîtres."

138 There is a problem here in the manuscripts on which al-Hīlah relied for his edition of al-Burzulī. He notes (1:587) that two of the three manuscripts contain an illegible word, while the third reads, "fa-qāla khamsūn wa-qad wajadāhu fì al-țarìq al-ghālib al-salāma."

139 This must be the nineteenth year of the 40os AH, when both Abū 'Imrān and Ibn 'Abd al-Raḥmān might have encountered a pilgrim passing through Qayrawān. The pilgrim appears to disagree with their assessment, saying that the route is generally safe.

140 This is likely Abū Muḥammad 'Abd al-Ḥaqq al-Ṣiqillī (d. 466/1073-4), who studied in Qayrawān with Abū 'Imrān al-Fāsī. He performed the hajj twice and composed a number of works. Several of his opinions are preserved in al-Wansharīsì's Mi'yār. See Makhlūf, Shajarat al-nūr, 1:173; Ibn Farḥūn, al-Dībāj, 275. 
Ibn Hamdīn [d. 521/1127 $]^{141}$ issued a fatwā regarding a man who was physically and financially capable of performing the pilgrimage, [stating:] If he is one of the people of al-Andalus or a neighboring region, ${ }^{142}$ and he is capable of $j i h \bar{a} d$, then [jihād] is more imperative for him than the hajj, and the expenditures entailed are of greater merit.

I [viz., al-Burzuli] said: This likely concerns someone who has already performed the obligatory pilgrimage, as Ibn Rushd stated. Alternatively, [Ibn Hamdinn's opinion may also apply to] someone who has not yet performed the pilgrimage, in accordance with the opinion that [the hajj] may be delayed and the prescribed period for its performance is flexible. As has been noted, this is the doctrine transmitted [by Mālik and his early followers], even if some objections to adopting this position are considered within the [school's] lengthier volumes.

\section{Appendix C: Two Fatwās by Ibn Rushd al-Jadd (d. 520/1126)}

\section{First Question ${ }^{143}$}

The Commander of the Muslims and Defender of the Religion, 'Alī b. Yūsuf b. Tāshufīn - may God prolong his rule and heighten his victory - wrote to him [viz., Ibn Rushd] - may God be pleased with him - asking him if hajj or jihäd is of greater merit for the people of al-Andalus. ${ }^{144}$

The text of the question: "In the name of God, the Merciful, the Compassionate. May God bless our master Muhammad and his family, and grant him peace. Your answer - may God be pleased with you - [is requested] concerning those Andalusīs in our time who have not performed the pilgrimage. Is hajj more meritorious for them or jihād? What about [those who] have completed the obligatory pilgrimage? Go over

141 Abū al-Qāsim Aḥmad b. Muḥammad b. Ḥamdīn (d. 521/1127) was appointed chief judge of Córdoba by 'Alī b. Yūsuf b. Tāshufīn, both before and after Ibn Rushd al-Jadd held this post. See Serrano Ruano, "Ibn Rushd al-Jadd," 301. The Almoravid amīr presumably posed the same question regarding the relative merit of jihäd and hajj to both chief judges.

142 The text reads n-z-r mujāwir, which I have emended to qutr mujäwir to fit the sense of the passage.

143 My translation of this first question and its addendum are based on Ibn Rushd al-Jadd, Fatāwā Ibn Rushd, ed. al-Mukhtār b. al-Ṭāhir al-Talīlī, 3 vols. (Beirut: Dār al-Gharb al-Islāmī, 1987), 2:1021-27. This fatwā is also included in al-Burzulī (1:584) and al-Wansharīsī (1:4323). Serrano Ruano included a partial translation of this fatwā in "Ibn Rushd al-Jadd," 315-6, while Camilo Gómez-Rivas offered the first full translation of it in his Law and the Islamization of Morocco under the Almoravids: The Fatwās of Ibn Rushd al-Jadd to the Far Maghrib (Leiden: Brill, 2014), 170-1. See also Gómez-Rivas, Islamization, 93-98. My translation differs substantially from that of Gómez-Rivas.

Ahl al-Andalus, "the people of al-Andalus" is henceforth translated "Andalusīs." 
your thoughts on this matter for us. [May you be] rewarded and granted success, if God wills."

\section{Answer}

He answered this - may God prolong his fortune - with the following text:

May God have mercy on me and on you. I have examined this question of yours and reached an understanding of [the matter]. The obligation to perform the pilgrimage has lapsed in our times for Andalusīs because of [their] lack of ability - which God has made a condition of the obligation - because 'ability' means the capacity to arrive with security of person and property, and this [capacity] is nonexistent in our age.

Once the obligation to perform the pilgrimage has lapsed for this reason, it becomes supererogatory, [and] reprehensible because it is a hazardous undertaking. ${ }^{145}$ It is therefore clear from what we have mentioned that jiha $\bar{a} d$ - the merits of which are innumerable in the Qur'ān, in well-attested prophetic traditions, and in reports concerning the Companions - is of greater merit than [hajj]. This is too obvious to require a question.

The proper question, rather, concerns those who have completed the obligatory pilgrimage, and [for whom] the routes are safe. Is pilgrimage or jihād of greater merit [for them]? My opinion is that jihäd is preferable for them, because of the great merit accrued by it.

As for those who have not completed the obligatory pilgrimage, and [for whom] the routes are safe: This [rule] is derived according to [the jurist's position] on a matter of scholarly disagreement: Must hajj be performed immediately [upon meeting the condition of ability], or may it be deferred? This [choice] [applies only if] the obligation to wage jihâad no longer applies to [all capable] individuals because [this collective obligation] has been met by those performing it. As for a place in which [jihād] is required of [all capable] individuals, one position [is agreed upon] - jih $\bar{a} d$ is of greater merit than the obligatory pilgrimage. This is because of the difference of opinion regarding [hajj] as to whether it must be performed immediately or may be deferred. ${ }^{146}$ May God grant us success.

145 This hazardous undertaking may be a reference to Qurān 2:195, noted above in Appendix A, which instructs believers not to cast themselves into destruction by their own hands.

146 That is, if there is a validly derived opinion in the school according to which the hajj may be delayed, this opinion must be adopted in the face of a strong individual obligation to wage jihād, as a clear way to reconcile both obligations at a time when the individual likely meets the obligations for both (e.g. fitness and the ability to travel). 


\section{Addendum}

[Ibn Rushd] - may God have mercy on him - appended the following to his answer, after the Commander of the Muslims had asked him about the people of the [other] shore [viz., the Maghrib], in Ceuta, at the beginning of the year $515 \mathrm{AH}$ [1121 CE]: "Are they like the Andalusīs in this regard, or not?" He said:

With regard to those Maghribīs who are equivalent to Andalusīs, whose route is the same as that of the Andalusīs: If they cannot arrive in Mecca without fear for their persons and property - or [even] if they do not fear for their persons or their property before reaching Mecca - then my position is that jihād is of greater merit for them than hastening to perform the pilgrimage. This is because the view has been held that [hajj] may be deferred. This [view] is the correct one in the opinion of Mālik - may God have mercy on him - as his treatment of various legal issues (masā̃il) indicates.

This [answer] applies [only to people] other than those who undertake the obligation of jihād. As for the Muslims' protectors and soldiers who undertake the obligation of jihād-jihād is what is required of them. Hastening to perform the pilgrimage is not incumbent upon them except with regard to those who have reached old age, ${ }^{147}$ because this deferred obligation has a condition during which it becomes incumbent - and that is the point at which a legally responsible person comes to believe that by his deferring [longer], he will miss [fulfilling the hajj]. The limit of this [deferral is indicated by] the Messenger of God's statement: "My community's 'old age' is between sixty to seventy [years]."148 May God - may He be exalted - grant us success. He has no partner.

\section{Second Question ${ }^{149}$}

[It is recorded] in another place that Ibn Rushd was told: "The scholars of our day are saying that the duty to perform the pilgrimage is not obligatory for Andalusīs at this

147 The term translated as "old age" here, al-mu'tarak (literally, "battlefield"), is taken from the hadìth cited below. Other versions of the hadīth use the more common a'mār (life spans), or read mu'tarak al-manāyā (destiny, death) instead of mu'tarak ummatī. These expressions, which suggest that a struggle with death begins at a certain age, appear to describe the community's average life expectancy.

148 Several versions of this ḥadìth are preserved. On the variants, see Aḥmad b. 'Alī b. Ḥajar al-'Asqalānī (d. 852/1449), Fatḥ al-Bārī bi-sharh Șaḥịh al-Bukhārī, Kitāb al-Riqāq, Bāb man balagha sittīn sana fa-qad a'dhara Allāh ilayhi fì al-'umr.

149 This second question is found in al-Burzulī (1:584-6), but not in al-Wansharīsī. The editor of Fatāwā Ibn Rushd has included this material, taken from al-Burzulī but with minor modifications, in a footnote accompanying the first question and its addendum (Fatāwa 
time, because of the varieties of corruption that have appeared and the universality of the fear that has arisen."

\section{Answer to Second Question}

He responded:

What is obligatory is a conviction that Andalusīs are like everyone else with regard to the obligation to perform the pilgrimage, because those passages of the Qurān with general import ${ }^{150}$ pertain to them. Thus, whenever they find a path, by land or sea, by walking or riding, the pilgrimage is obligatory for them, as long as they have the ability to undertake it. If the necessary provisions are lacking, then the case proceeds according to the usual [rule]. ${ }^{151}$

If no path exists other than by expending money to protect themselves against thieves, and if [the amount] is not injurious or exorbitant, then the pilgrimage remains incumbent upon them. If they are in the opposite [situation], then the duty to perform the pilgrimage lapses until they find [a clear path].

He was asked about Andalusīs only because they must travel by sea to reach [their destination]. ${ }^{152}$ This is permitted by the Qurān and by tradition (al-athr) so long as travelling by sea does not entail risk - namely, fear of an enemy, or a corrupt Muslim, or [embarking] at a time unsuitable for sailing. ${ }^{53}$ In these cases, the obligation lapses for either the land route or the sea, because of the lack of ability.

Ibn Rushd, 2:1021-22 n.1). This section has not been translated previously. The presentation of the question appears to be truncated as it fails to anticipate Ibn Rushd's response, in the fatwa 's final paragraph, to a request for a proof-text mentioning al-Andalus.

150 Text: 'umūm al-Qur'ān, that is, passages whose implications are general ('âmm) rather than specific $(k h \bar{a} s ̦$ ș $)$. This means that any passage that applies to all Muslims applies to Andalusī Muslims, as no specific text exempts them. On the "general" and "specific" import of Qurān 3:97, obligating Muslims to perform the pilgrimage, see Mohammad Hashim Kamali, Principles of Islamic Jurisprudence, 3 rd ed. (Cambridge: Islamic Texts Society, 2003), 143 .

151 As provisions are an integral part of "ability," the "usual rule" here means that someone without provisions is not able to perform the pilgrimage, and therefore not obligated to do so.

152 "Wa-innama su’ila 'alä (sic) ahl al-Andalus ..." As this sentence reverts to al-Burzulī's editorial voice, it is unclear whether the following paragraphs represent al-Burzulīs commentary or a continuation of Ibn Rushd's answer. The final paragraph, which addresses a questioner in the second person, appears to be Ibn Rushd's voice. I have set off in block quotations the material most clearly attributed to Ibn Rushd.

153 In rough weather or during the worst part of winter, for example. This paragraph is garbled in the footnotes to Fatāwa Ibn Rushd. 
It was debated: What if there is an oppressor enroute who prevents arrival in Mecca unless money is given to him?

Some [scholars] said: If [the amount] is injurious, [the obligation] lapses. If it is not injurious, and the oppressor is known for fidelity and a lack of treachery, then the obligation to perform the pilgrimage does not lapse, and he must be given what he requests.

Others said: [Hajj] is not required until the prohibiting factor (māni ) ceases and disappears, regardless of whether the requested [sum] is little or great. The reasoning behind this [view] is that [with] the taking of money in an unjust manner, it cannot be guaranteed [that the oppressor] will not engage in perfidy or treachery. Thus the person [paying the oppressor] exposes himself to danger, and this is prohibited.

The first [of these two positions] is predominant, [that is,] if [the oppressor] requests a small amount and he is known for his lack of treachery, [then the hajj remains obligatory]. [This position is supported] by an analogy to the [case of] a man who lacks water. He is obligated to buy it, even in large quantities, if he is not thereby injured [financially]. If this does injure him, the [water's] purchase is not required of him.

No [scholarly] disagreement has occurred regarding the [payment] given to a guard to protect against thieves, so long as it is not much.

The disagreement regarding the [payment] given to oppressors arises because [the transaction] is not guaranteed against violation. A guard is not an oppressor with regard to the [payment] he receives, as he is not like them [viz., oppressors]. Rather, he is a hired laborer, thus it is necessary to place confidence in him.

[Ibn Rushd continued]:

As for your request for a tradition $\left(a t h r^{i n}\right)$ indicating that the obligation to perform the hajj has lapsed for Andalusīs: If you mean a tradition concerning alAndalus in particular - then there is no clear text in the Book ${ }^{154}$ or the sunna indicating that the hajj has lapsed for Andalusīs or for any other Muslims. If you mean a tradition indicating this [same] lapse as a result of the difficulty that has arisen in finding a means [to perform the pilgrimage], and the conspicuousness of the corruption that has appeared on land and sea - then the Book and the agreement [of the scholars] are among [the sources] that demonstrate this lapse [in the obligation to perform the pilgrimage]. God knows best. 


\section{Appendix D: Fatwā by 'Abd al-Hādī al-Ḥusaynī al-Ṣiqillī}

(d. 1311/1893)

\section{Question - Posed by King Hasan I (r. 1873-94 $)^{155}$}

Praise be to God, and blessings and peace be upon our lord Muhammad, the Messenger of God, and upon his family, his Companions, and those who follow him. What say our masters the eminent scholars, the lamps of Islam - may God perpetuate through them the benefit of all 156 - concerning [a situation] that is arising among some of the laymen, [namely, a man's] setting forth toward the sacred house of $\operatorname{God}^{157}$ without sufficient means to sustain himself for the duration of his absence? And concerning his outward and return journeys, and his throwing himself because of that [viz., his insufficient means] into danger and destruction? ${ }^{158}$ For it has circulated widely, and has been continually repeated on the tongues of those with sound judgment as well as others who have heard it through hearsay, that most of those who set forth in the condition described are generally prevented [from completing the journey] when the [provisions] they have with them are exhausted along the way. This is in addition to the vindictive satisfaction afforded to Jews and Christians by someone in this condition, and their contempt for him because of his shabby appearance, his filthy, worn-out clothes, and the fact that his lodging - generally, when he enters cities - is in the passageways and marketplaces, because he does not have sufficient resources to rent lodging and lacks any specific accommodation of which to avail [himself]. This [situation] naturally encourages our enemies' malicious joy at the expense of the people of Islam. [Muhammad] - peace be upon him - sought God's protection from this [condition],

155 My translation is based on a manuscript copy of this fatwa , bound together with various unrelated texts in MS 11355 of the Hasanīya (Royal) Library, Rabat. The manuscript pages are unnumbered. An editor's note on the folio preceding the beginning of the manuscript reads: "Praise be to God. A question and its answer, related to explaining the condition of ability for performing the pilgrimage. By the two judges of Fez at that time, in the handwriting of one of them, Sīdī al-Hādī al-Siqiillī. There is another copy of it, in the hand of 'Uthmān b. Sūda, an eight-page booklet in a red volume. Both of them are conveyed from the distinguished royal books in the Bāb al-Namūra al-Saīda library." The full fatwā has been published, with a number of typographical errors and slight abridgments, in Abū 'Īsā Muḥammad al-Mahdī al-Wazzānī (d. 1342/1923), al-Nawāzil al-ṣughrā, al-musammā: Al-Minah al-sāmiya fì al-nawāzil al-fiqhīya, 4 vols. ([Rabat]: Wizārat al-Awqāf wa'l-Shu'ūn al-Islāmīya, 1992-1993), 1:291-97.

156 al-khāsșs wa'l-'ämm, "the elite and the commoners."

157 The Ka'ba in Mecca.

$15^{8}$ This is a reference to Qur'ān's instruction to believers not to cast themselves into destruction by their own hands, a warning against self-harm and risk-taking. This is the same verse alluded to in the question posed to al-Lakhmī and in Ibn Rushd's fatwa 
and the obligation to undertake the pilgrimage was made conditional upon the ability to do so, as the magnificent Qurān states explicitly. The condition of ability to undertake the pilgrimage, according to the Mukhtașar, 159 "is met through the capacity to arrive [in Mecca] without great hardship, and with security of person and property." (Khalīl ibn Ishạāq). In regard to this matter, is it obligatory to restrain those who would do this, to prevent and forbid them from setting forth whenever they do not possess what is necessary to sustain them there and back, considering the scandalous acts that have been mentioned before? Or not? Respond, may you be rewarded [for your reply], and may be peace be upon you.

\section{Answer}

Praise be to God, and blessings and peace be upon our lord, the Messenger of God. The answer - and God grants success in determining what is right - is that one of the required tenets of the religion is that the pilgrimage is a pillar of Islam, obligatory upon those who are able to undertake it. This is on the authority of the Book ${ }^{160}$ and the sunna and consensus. Our Lord said - may His loftiness be exalted: "Pilgrimage to the House is an obligation people owe to God, whoever is able to find a way."161 [Muhammad] said - may God bless him and grant him peace - as it is recorded by Imām Muslim, on the authority of 'Umar ibn al-Khațāa,,162 - may God be pleased with him - in response to Gabriel's question - peace be upon him - to the Prophet - may God bless him and grant him peace - concerning Islam, he [viz., Muhammad] said may God bless him and grant him peace - in his reply: "[Islam is] that you testify that there is no God but God and that Muhammad is the Messenger of God, that you establish prayer, pay the obligatory alms, fast during Ramadān, and perform the pilgrimage to the House if you are able to find a way."163 The community's consensus has been established to this effect.

[As] you yourself observe, the Lawgiver has made 'ability' a condition for undertaking the pilgrimage. It is debated whether this [ability] is a condition of obligation or a

159 The Mukhtașar, or Abridgment, of Mālikī law by Khalīl b. Isḥāq al-Jundī (d. 776/1374), an Egyptian, became a central textbook of the Mālikī school. On Ibn Isḥāq, see Ibn Farḥūn, al-Dībāj, 176; $E I^{2}$, s.v. "Khalīl b. Ishāāk" (M. ben Cheneb); Makhlūf, Shajarat al-nūr, 1:321; al-Ziriklī al-A`làm, 2:315.

160 The Qurān.

161 Qửān 3:97.

162 'Umar ibn al-Khațtāa (r. 13-23/634-644), second caliph and Companion of the Prophet.

163 Șaḥh Mūslim, Kitāb al-İmān, 1. In this famous hadīth, the angel Gabriel appears as a man and asks Muhammad to describe Islam. 
condition of validity. ${ }^{164}$ The eminent scholar al-Hattāāb, ${ }^{165}$ commenting on the master Khalil's statement "and it is obligatory on the condition of ability," writes the following:

Most of the scholars of the [Mālikī] school of law make 'ability' a condition of obligation. Ibn Bashīr, ${ }^{166}$ Ibn Shās, ${ }^{167}$ Ibn al-Haājib, ${ }^{168}$ the Compiler in his book on the pilgrimage rituals, ${ }^{169}$ Ibn 'Arafa, ${ }^{170}$ and others are in accordance with this. The position was advanced by some of them, including Ibn al-Hājj, ${ }^{171}$ that it is a condition of validity; al-Tādilī172 reports this of him [viz., Ibn al-Ḥājj] after mentioning the first opinion. [Al-Damīrī] points to both [positions] in al-Shāmil, ${ }^{173}$ then states: "Ability is a condition for its obligation, not for its validity; this [opinion] is more sound."

Then he [viz., al-Hatțāb] mentions [additional points] that pertain to these two opinions. Thus [you may] look into this [matter in Mawāhib al-Jalïl].

164 'Ability' as a condition of obligation means that the pilgrimage is not obligatory for someone who is unable to perform it. As a condition of validity, it would mean that if someone who does not meet the requirements for 'ability' performs the pilgrimage, his pilgrimage is invalid for the purpose of fulfilling the once-in-a-lifetime obligation.

165 Abū 'Abd Allāh Muḥammad b. Muḥammad al-Ḥaț̣āa (d. 954/1547), a Mālikī jurist from Mecca, wrote Mawāhib al-Jalīl li-sharh Mukhtașar Khalīl (Gifts from the Glorious for Explaining Khalil's Abridgment), one of the most influential commentaries on the Mukhtașar of Khalīl b. Ishāāq. On al-Ḥațțāb, see Makhlūf, Shajarat al-nūr, 1:389-9o; al-Ziriklī al-A`làm, 7:58.

166 Ibrāhīm b. 'Abd al- Șamad b. Bashīr (d. after 526/1131). Ibn Farḥūn, al-Dībāj, 142-3.

167 Abū Muḥammad 'Abd Allāh b. Najam b. Shās (d. 610/1213). Ibn Farḥūn, al-Dībāj, 229-30.

168 Jamāl al-Dīn b. 'Umar b. al-Ḥājib (d. 646/1248), a Mālikī jurist who worked primarily in Egypt, wrote Jāmi' al-Ummahāt (also known as al-Mukhtașar al-far ‘̄ ), of which Ibn Ishāà's Mukhtașar is an abridgment. Ibn Farḥūn, al-Dībāj, 289-91; Makhlūf, Shajarat al-nūr, 1:241.

169 Khalīl b. Isḥāq, who is referred to as the "Compiler" (al-mușannif) in al-Ḥaț̣āb and elsewhere, also wrote a book on pilgrimage rituals, entitled Manāsik al-hajj.

170 Abū 'Abd Allāh Muḥammad al-Warghammī b. 'Arafa (d. 803/1401). Ibn Farḥūn, al-Dībāj, 419-20; $E I^{2}$, s.v. "Ibn 'Arafa" (Hady Roger Idris); Makhlūf, Shajarat al-nūr, 1:326-27; al-Ziriklī al-A'ām, 7:43.

171 Ibn al-Ḥājj (d. 529/1134), the chief judge of Córdoba mentioned in Appendix B.

172 Aḥmad b. 'Abd al-Raḥmān al-Tādilī al-Fāsī (d. 741/1340-41), a Mālikī jurist from Fez who settled in Medina. Ibn Farhūun, al-Dībāj 138.

173 This work is al-Shāmil fì al-figh (The Comprehensive Work of Law), by Bahrām b. 'Abd Allāh b. 'Abd al-'Azīz al-Damīrī (d. 805/1403), a Mālikī jurist from Egypt. Makhlūf, Shajarat al-nūr, 1:344-5; Shams al-Dīn Muhammad b. 'Abd al-Raḥmān al-Sakhāwī (d. 902/1497), al-Ḍaw' al-lāmi' li-ahl al-qarn al-tāsi', 12 vols. in 6, ed. 'Abd al-Lațîf Ḥassan 'Abd al-Raḥmān (Beirut: Dār al-Kutub al-'Ilmīya, 2003), 3:19. 
Once you have understood this [the foregoing], then [know that] the masters of independent reasoning (ijtihād) differed in explaining the meaning of 'ability.' The master and judge al-Bayḍāwī, ${ }^{174}$ in his exegetical work Anwār al-tanzīl wa-asrār alta'will (The Lights of Revelation and Secrets of Interpretation), commenting on the words of [God] - may He be exalted - "whoever is able to find a way," wrote the following:

Substituting for 'people' [a word designating] some of them rather than all of them is a specification of it [viz., the word 'people']. ${ }^{175}$ The Messenger of God may God bless him and grant him peace - explained the condition of ability as being met by provisions for traveling and an animal for riding. This supports al-Shāfi î's ${ }^{176}$ opinion - may God the Exalted be pleased with him - that it is met through wealth; for this reason, he made it obligatory for a slave to perform the pilgrimage by proxy, if he possesses the wage required to hire someone to undertake it on his behalf. Mālik ${ }^{177}$ - may God the Exalted have mercy on him - said that it is met by the body, and thus obligatory upon whomever is capable of walking and of earning an income along the way. Abu Hanifa ${ }^{178}$ - may God the Exalted have mercy on him - said that it consists of both of these matters together.

One learns from al-Hatțāb that the doctrine of Imām Aḥmad ${ }^{179}$ - may God the Exalted have mercy on him - is similar to the doctrine of the Hanafîs in this regard.

174 'Abd Allāh b. 'Umar b. Muḥammad b. 'Alī al-Shīrāzī al-Bayḍāwī (d. 685/1286), a Shāfíī jurist and judge. Al-Ziriklī al-A'àm, 4:110.

175 In the clause of Qur'ān 3:97 referred to here (wa li-llāhi 'alā al-nās hajjj al-bayt, man istațāa sabīlan), the word al-nās is general ('âmm) in meaning, designating all people. Al-Bayḍāwī states that "people" is then made specific (khạsṣ) in meaning by the word "man," meaning "whoever." This specification means that only those people who are able to do so are obligated to undertake the pilgrimage. On the general and specific meanings of words in the context of this verse, see Kamali, Principles, 143.

${ }_{176}$ Abū 'Abd Allāh b Muhammad b. Idrīs al-Shāfīi (d. 204/820), eponymous founder of the Shāfici school of law. $E I^{2}$, s.v. "al-Shāfī̄" (E. Chaumont).

177 Mālik b. Anas (d. 179/795), eponymous founder of the Mālikī school of law. EI², s.v. "Mālik b. Anas" (J. Schacht).

178 Abū Ḥanīfa al-Nu'mān b. Thābit (d. 150/767), eponymous founder of the Ḥanafĩ school of law. $E I^{3}$, s.v. "Abū Ḥanīfa" (Hiroyuki Yanagihashi).

179 Aḥmad b. Hanbal (d. 241/855), eponymous founder of the Hanbali school of law. $E I^{3}$, s.v. "Aḥmad b. Ḥanbal" (Livnat Holtzman). The printed version of al-Wazzānī erroneously records "Mālik" here instead of "Aḥmad." 
The [position] he attributes to the master of masters, the eminent scholar of the Land of the Hijra, ${ }^{180}$ our Imām Mālik - may God be pleased with him - is the accepted doctrine (mashhür) of his school. It is this [view] that the author of the Mukhtasar expounds in his statement: “... is met through the capacity to arrive [in Mecca] without great hardship, and with security of person and property ..." up to his statement, “... even if without provisions for traveling or an animal for riding, in the case of one who has a trade with which to support himself." Then he [viz., Ibn Ishāa] states, “... it may not be met through a debt or a gift or any manner of begging, and he must allow for the [provisions necessary] for his return if he fears he might perish [if he remains in Mecca]." 181

After reporting the accepted doctrine, the eminent scholar al-Hattāb wrote ${ }^{182}$ the following [regarding] the position countering the mashhür - that is, that 'ability' consists of provisions for traveling and an animal for riding: "It is said: 'Ability' means provisions for traveling and an animal for riding, and this is the opinion of Sahnūn ${ }^{183}$ and Ibn Habīb."'184 Thus, this position is in agreement with the doctrine of Imām al-Shāfí̄ - may God be pleased with him - on this point. Al-Hatțāb also wrote, ${ }^{185}$ "al-Tādilī reports that al-Māzarî̀ ${ }^{186}$ said that 'ability' consists of arriving at the House without hardship, security of person and property, the capacity to perform the ritual obligations, and the capacity to abstain from negligence and from objectionable actions."

Thus, one learns from this [discussion] that ability is required, and whoever does not have the ability to undertake the pilgrimage does not have the obligation, espe-

180 Medina.

181 Al-Ḥatțāb reviews several opinions regarding this point. Many jurists held that a pilgrim meets the condition of 'ability' if he is able to arrive in Mecca, regardless of his demonstrated capacity to return. Others held that if the pilgrim fears that he will perish if he remains in Mecca (presumably without support or protection), then he must demonstrate the ability to return home, or at least to travel to the nearest locale wherein he could make a living. See Abū 'Abdallāh Muḥammad b. Muḥammad al-Ḥaț̣āb (d. 954/1547), Mawāhib al-Jalïl li-sharh Mukhtașar Khalïl, ed. Zakariyā 'Umayrāt (Beirut: Dār al-Kutub al-Ilmīya, 1995), 3:474-5. For the relevant passage in the Mukhtașar itself, see Khalil b. Ishāa al-Mālikī, Mukhtaṣar al-'alāma Khalīl fì figh al-imām Mālik, ed. 'Abd al-Salām al-Shatīwī (Casabalanca: Dār al-Rashād al-Ḥadītha, 2003), 61.

182 Al-Ḥaț̣āâ, Mawāhib al-Jalīl, 3:448.

183 'Abd al-Salām Sahnūn b. Sa'īd (d. 240/854) compiled al-Mudawwana al-kubrā, one of the Mālikī school's foundational texts. Ibn Farhūun, al-Dībāj, 263-68; Makhlūf, Shajarat al-nūr, 1:103-105. Al-Wazzānī leaves out much of this sentence.

184 'Abd al-Mālik b. Ḥabīb al-Sulamī (d. 238/852), an Andalusī Mālikī jurist, wrote al-Wāḍiha fì al-sunan wa'-figh, a Mālikī textbook. Makhlūf, Shajarat al-nūr, 1:111-2.

185 Al-Ḥațtāâ, Mawāhib al-Jalīl, 3:478.

186 Abū 'Abd Allāh Muhammad b. 'Alī b. 'Umar al-Māzarī (d. 536/1141). His fatwās are translated in Appendix B. 
cially when he is in the condition described in the question. Al-Hațāb has also reported $^{187}$ that al-Māzarī said that the master $A b \bar{u}$ al-Walīd ${ }^{188}$ issued a legal opinion stating that the obligation of pilgrimage is not in effect for the people of al-Andalus, and that al-Turțūshī189 issued a legal opinion stating that it [viz., pilgrimage] is prohibited for the people of the Maghrib, and that if someone assumes the risk of undertaking the pilgrimage, his obligation ceases, and he is a sinner as a result of the risk he has assumed. A similar statement has been reported concerning the master Ibrāhīm alLaqānī, 190 who, when he performed the pilgrimage, rode his mule. When he stood at 'Arafa, he said: "Whoever knows me, knows me; and whoever does not know me, I am Ibrāhīm al-Laqānī. The obligation of pilgrimage is not in effect in this age."191

Imām Ibn al-'Arabīị2 examined this [issue], as did the master Zarrūq, ${ }^{193}$ according to what al-Ḥațāa reports, ${ }^{194}$ as follows: "The master Zarrūq, in Sharh al-Waghlīsīya, states that the opinion of whoever says, "The obligation of pilgrimage is not in effect for the people of the Maghrib' [shows] a lack of professional etiquette, even if that [viz., lack of obligation] is the state of affairs. It is better to say that the ability to perform the pilgrimage is nonexistent in the Maghrib, and that whoever does not have the ability, does not have the obligation."

187 Al-Ḥațtāā, Mawāhib al-Jalīl, 3:455-6.

188 Abū al-Walīd Muhammad b. Aḥmad b. Aḥmad b. Rushd al-Jadd (d. 520/1126). This is the first opinion translated in Appendix C.

189 Muḥammad b. al-Walīd b. Muḥammad Abī Bakr al-Ṭurțūshī (d. 520/1126), a Mālikī jurist originally from Tortosa but who traveled widely and died in Fez. Makhlüf, Shajarat al-nūr, 1:183-4; al-Ziriklī, al-A'lām, 7:133-4.

190 Ibrāhīm b. Ibrāhīm al-Laqānī (d. 1041/1631), an Egyptian Mālikī jurist who died while returning from the pilgrimage. Makhlūf, Shajarat al-nūr, 1:421-2; al-Ziriklī, al-Ađ'̄̄m 1:28.

191 This appears to be a play on a statement attributed to Mālik. According to the story, the caliph Abū Jacfar al-Manșūr ordered that Mālik be beaten, shaved, and paraded on a camel for narrating a hadìth report denying the validity of a divorce obtained by coercion. When ordered to denounce himself publicly, Mālik responded, "Whoever knows me, knows me, and whoever does not know me, I am Mālik b. Anas b. Abī 'Āmir al-Aṣbahīi, and I say that the divorce of the coerced has no effect." See Abū Nu'aym Aḥmad b. 'Abd Allāh al-Ișfahānī (d. 430/1038), Hilyat al-awliyā’ wa țabaqāt al-aşfiyā' (Beirut: Dār al-Kutub al-Ilmīya, [1988?], 6:317. Mālik was implying that an oath of allegiance to al-Manșūr was not binding if given under duress. See Yossef Rapoport, "Mālik b. Anas (d. 179/795)," in Islamic Legal Thought, ed. Arabi et al., 28.

192 Ibn al-'Arabī (d. 543/1148). See note 71 for biographical sources.

193 Aḥmad Zarrūq (d. 899/1493). See note 69 for biographical sources. Sharh al-Waghlīsīya is a commentary on al-Waghlīsìya by Abū Zayd 'Abd al-Rahmmān b. Aḥmad al-Waghlīsī (d. 786/1384). Makhlūf, Shajarat al-nūr, 1:342.

194 Al-Ḥaț̣āb, Mawāhib al-Jalīl, 3:455. 
According to some scholars, what is evidently the correct doctrine (al-zāhir) [of the Mālikī school] is this: If [performing the pilgrimage] leads to a failure to fulfill a religious duty, then it is prohibited, and the view of those who prohibit applies in this case. If [performing the pilgrimage] leads to the endangerment of person or property, it does not thereby reach the level of prohibition, and the view of Ibn al-Arabì and those who agree with him applies in this case. Consider this - and God knows best.

The master and imām Abū 'Abd Allāh Ibn al-Hājj, 195 in al-Madhkal, after a valuable discussion refuting what many pilgrims do, writes the following: ${ }^{196}$

One of them may not succeed in obtaining funds from powerful people through his own [efforts], nor is he able to reach them [viz., the powerful] through anyone else. ${ }^{197}$ Thus he sets out with neither provisions nor a mount, and numerous situations develop that he could have done without. Among them is an inability to perform the ritual prayer, which is a transgression. Among them is a lack of nourishment, falling into hardship and fatigue, and burdening people with the provision of his food and drink. Often his condition eventually leads to death, which is the most frequent case. Thus you find them [viz., unprepared pilgrims] along the route, cast to the ground dead, after having violated the command of God - may He be exalted - as regards a duty to themselves, ${ }^{198}$ and having implicated in their sin their brothers, their Muslim fellow travellers who were aware of their condition. Likewise, anyone who aids them at the beginning of their

195 Abū 'Abd Allāh Muḥammad b. Muhammad b. Muḥammad al-'Abdarī, known as Ibn al-Ḥājj (d. 737/1336), wrote al-Madkhal ilà tanmiyat al-'amāl bi-tahsiñn al-niyyāt wa'-tanbīh 'alā ba'd al-bida' wa'l-'awā'id allatī untuhilat wa bayān shanā'atihā (The Entry into Advancing Actions by Improving Intentions, and the Notice Concerning Some Innovations and Customs that Have Been Adopted, and their Repulsiveness). Makhlūf, Shajarat al-nūr, 1:313.

196 For the following passage, see Ibn al-Ḥājj, al-Madkhal, 2:396-7.

197 In the passage he is quoting from al-Madkhal, al-Ṣiqillì has substituted "ilā amwāl al-musallițīn" for Ibn al-Hāijj's "ilayhī," in order to clarify the reference. This passage about someone who sets forth on pilgrimage without sufficient funds follows one in which Ibn al-Ḥajj discusses pilgrims who procure enough money for the journey in illegitimate ways, including seeking money from "al-mutasallițin 'alāal-muslimīn," those who exercise power over the Muslims and whose tyranny is only increased by their appeals for money. It is unclear precisely whom Ibn al-Ḥājj has in mind. Ibn al-Ḥājj, al-Madkhal, 2:396.

198 Muslim jurists distinguish between ḥuqūq Allāh, the rights of God, i.e., duties such as prayer and pilgrimage that men owe to God; and huqūq al-ibād, the rights of men, which include doing no harm to oneself or others. Ibn al-Hājj argues that the pilgrims referred to here have violated illegitimately a duty owed to themselves in their attempt to fulfill a duty owed to God. See Anver Emon, Islamic Natural Law Theories (New York: Oxford University Press, 2010). 
journey with some support that will not be sufficient for them, or who exerts himself on their behalf in this, also sins; unless he knows that another person will provide them with that which will complete the sum necessary for the outward journey and the return; in that case there is no harm. But if he does not know this, it is forbidden for him to give to them, because this [aid] enables them [to continue along the route, where they will] succumb to thirst, hunger, and fatigue, over which they have no power; and facilitates their reaching the point of death, which is the most frequent case. Thus, he is a partner with them in what befalls them, and [he is party to] the anger, discontent, and cursing that some of them exhibit. This is the opposite of the case in which they are already on their way in this condition, for [in that case] it is incumbent upon anyone who learns of their condition to aid them with whatever is possible at the time, even a drink and a bite to eat, and to inform them that what they are committing is forbidden to them and that it is not permitted for them to repeat anything similar. The cause of all of this is ignorance of the true facts of worship, what is obligatory in it [viz., worship], prohibited, recommended, and not recommended.

This has come [to us] through a clear text, from a hadīth of Anas b. Mālik ${ }^{199}$ may God be pleased with him - in which he said: "The Messenger of God - may God bless him and grant him salvation - said: "There will come upon the people a time when the rich among them perform the pilgrimage for entertainment, those among them of middling wealth [perform the pilgrimage] for commerce, the Qur'ān reciters among them for show, and the poor among them in order to beg." 200 According to Ibn Rushd, the Qur'ān reciters are those who are devoted to worship. ${ }^{201}$ On account of these and similar themes, some of the scholars God's mercy be upon them - say, "the pious deed of the ignorant is greed, while the pious deed of the informed is obedience."

If this is so, then it is incumbent upon every legally responsible Muslim (almukallaf) to examine that which God - may He be exalted - has made obligatory upon him, and to initiate doing this [viz., that which is obligatory], on the condition of his being unimpaired by any faults.

199 Abū Ḥamza Anas b. Mālik (d. 93/711), a Companion of the Prophet and transmitter of hadìth reports. $E I^{2}$, s.v. "Anas b. Mālik" (A.J. Wensinck and J. Robson).

200 I have been unable to locate this hadith in any of the six major collections. It is recorded with slightly different wording in al-Khațīb al-Baghdādī's Tārīkh Baghdād and in 'Alī al-Muttaqī al-Hindì's Kanz al-'Ummāl.

201 As a gloss on this hadìth, muta'abbidūn may mean "those who make a show of being devout." Form v verbs occasionally have the sense of being a pretender (e.g. mutanabbī). 
Then he writes that many of them generally do not understand the rules with regard to their acts of worship, with the result that they bring about defects in their pilgrimage. Often one of them returns while he remains in a state of ritual consecration; ${ }^{202}$ and likewise other corruptions befall him. Thus, he is included in the general sense of the words of God, may He be exalted: "Say: Should we inform you of those who lose most through their deeds? ...". ${ }^{203}$ We ask God - may He be exalted - for success through His grace.

[The foregoing] is the discussion by the author of al-Madhkal, who has attained an extraordinary level of critical judgment and reached the utmost degree of excellence. The eminent scholar al-Hațtāb has recorded some of this, as has the critical judge Ibn Zikrī, ${ }^{204}$ in his commentary on al-Nașịha, ${ }^{205}$ regarding the master [Zarrūq]'s opinion:

The depravities of the pilgrimage are many. The most important of them are undertaking it with unlawful funds or with commission of a prohibited act, such as carelessness with regard to the required prayers and to ritually impure fluids and foods; ${ }^{206}$ and [undertaking the pilgrimage] in a state of humiliation, for those whose condition is disliked; and with flattery of them [from whom the pilgrim begs]; and [undertaking it] despite a failure to correctly establish the intention to perform it.

In his commentary on al-Bukhārī, the eminent scholar Ibn Zikrī, commenting upon the words of [God] - may He be exalted - "Provision yourselves for the journey, but the best provision is to guard against $\sin ^{, 207}$ states the following:

This means to avoid that which is sinful, including disgracing himself by begging when no state of adversity has compelled [the beggar], directing his covetous desires toward what people possess, and burdening them with hardship. From

202 This is the state of ihräm or temporary consecration that the pilgrim must enter prior to performing the pilgrimage. To exit the state of ihrām upon completion of the pilgrimage rites, men cut or trim their hair and remove the two-piece white garment worn during the pilgrimage.

203 Qurān 18:103. This verse and the ones following discuss those who believe themselves to be performing good works, but whose efforts are in vain.

204 Muḥammad b. 'Abd al-Raḥman b. Zikrī (d. 1144/1731), a Mālikī jurist from Fez. Makhlūf, Shajarat al-nūr, 1:484; al-Ziriklī, al-A'tām 6:197.

205 Aḥmad Zarrūq (d. 899/1493), noted above, also wrote al-Nașịha al-kāfiya li-man khașșahu Allāh bi'l-'äfiya (Sufficient Advice to Those Whom God has Granted Health and Safety).

206 A specific set of fluids and foods produce a state of ritual impurity, including urine, blood, wine, dogs, pigs, and the like.

207 Qửān 2:197. 
this one learns the ignorance of whoever risks his life and sets out on foot today for the pilgrimage, relying upon what people give him, which requires immense flattery and much self-abasement. For piety $(a l-\operatorname{taq} w \bar{a})$ in the verse includes what the individual does to defend his reputation and dignity against the humiliation of begging.

As for the master Zarrūq's words, "or with commission of a prohibited act, such as carelessness with regard to the required prayers ...," this is among the most significant of the depravities and corruptions. ${ }^{208}$ Al-Hattāa, commenting on the master [Ibn Ishāq]'s statement, “[Travel by] sea is on par with travel by land, unless his perdition is likely, or he omits an integral component of a required prayer due to a sickness,"209 wrote the following: ${ }^{210}$

This means that performing the required prayers is a condition of traveling by sea for the pilgrimage. It is appropriate for someone else to inform the traveler that he [must] carry out his required prayers within their set times, without omitting any of their obligatory parts. This is also not specific to travel by sea, but rather is an absolute condition for the obligation to undertake pilgrimage.

[Ibn al-Hājj] wrote in al-Madkhal:

Our scholars said: "If a legally responsible Muslim knows that he will miss even one prayer if he sets forth on the pilgrimage, then it has ceased to be an obligation upon him." Mālik - may God the Exalted have mercy on him - was asked about a man who travels by sea for the pilgrimage, and finds no place in which to prostrate other than on his brother's back:211 "Is the pilgrimage permitted for him?" He said - may God have mercy on him - "Should he travel where he does not pray?212 Woe to whoever neglects prayer, woe to whoever neglects prayer!"

208 Al-Wazzānī excludes this sentence.

209 Ibn Isḥāq, Mukhtașar, 61.

210 Al-Ḥaț̣āb, Mawāhib al-Jalīl, 3:477-8.

211 The phrase 'alä zahr akhīhi appears to be borrowed from discussions concerning the case of someone who participates in a Friday prayer, in a row other than the first one, and does not have room to prostrate without touching the person in front of him. This case is analogous to prayer on a ship too crowded to allow prostration. Al-Ḥațtāb, Mawāhib al-Jalill, 3:478-80.

The sense here seems to be, "How can he travel where he cannot pray?!" 
He said elsewhere that if the pilgrimage cannot take place except by performing the prayers outside of their set times and the like, it ceases to be an obligation. Al-Māzarī holds a similar opinion, as al-Hatțāb recorded. ${ }^{213} \mathrm{He}$ [al-Hatțāb] wrote after this: ${ }^{214}$

Ibn al-Munayyir, ${ }^{215}$ in his book on pilgrimage rituals, said: "Know that his omission of even one of the required prayers is a great sin (sayyia 'azima), for which the merits of the pilgrimage do not compensate. Rather, the balance is against him because prayer is more important [than pilgrimage]. Thus if he is prone to motion sickness when traveling by sea or riding an animal, even if it affects only one prayer, then he [should] refrain from undertaking the pilgrimage, or rather, the pilgrimage is prohibited for him when he cannot reach it other than by omission of required prayers ... Ibrāhīm b. Hilāl ${ }^{216}$ wrote in his book on pilgrimage rituals: "In sum, therefore let prayer, which is a pillar of the religion, be the most important of his concerns."

Then he [viz., Ibrāhīm b. Hilāl] said, "Due to the pilgrims' neglect of the required prayers, and their postponing [the prayers] beyond their set times, the scholars say that these people are disobedient."

Al-Hatțāb, after these reports and others, wrote the following:217

The result is that if traveling by sea will lead to a failure to perform prostration [during prayer], then [the pilgrim] should not travel by sea, and pilgrimage ceases to be an obligation for him. If he travels by sea and prays, he must always repeat [his prayers]. This is what is stipulated. And if [travelling by sea] leads him to pray seated, this case is similar to [that of praying without prostration, and the would-be pilgrim should not travel]. This [opinion regarding seated prayer] is indicated by the generally applicable statements (ițlāq) of the Compiler and of al-Burzulīi, ${ }^{218}$ and by what Ibn Abī Jamra ${ }^{219}$ has said, and by

213 See the above reference to al-Māzarī, where his definition of 'ability' includes the capacity to perform ritual obligations; this next passage from al-Ḥațāāb directly follows that earlier citation in Mawāhib al-Jalīl.

214 Al-Ḥaț̣āâ, Mawāhib al-Jalīl, 3:478.

215 Aḥmad b. Muḥammad b. Manșūr, known as Ibn al-Munayyir (d. 683/1284), Mālikī jurist and judge of Alexandria, Egypt. Al-Sakhāwī, al-Daw' al-lāmi', 132-3; Makhlūf, Shajarat al-nūr,1:269.

216 Ibrāhīm b. Hilāl al-Sijilmāsī (d. 903/1497-8), Mālikī jurist. Makhlūf, Shajarat al-nūr, 1:388.

217 Al-Ḥațțāb, Mawāhib al-Jalīl, 3:48o.

218 This is the same al-Burzuli (d. 841/1438) as noted earlier.

219 Abū Muhammad 'Abd Allāh b. Abī Jamra (d. 699/1299-130o), Andalusī Mālikī jurist. Makhlūf, Shajarat al-nūr, 1:285. 
al-Lakhmī's220 and Ibn 'Arafa's and Ibn Farḥūn's ${ }^{221}$ analogy between this case [viz., of seated prayer] and prostration on the back of one's brother. But what is indicated by al-Lakhmi's discussion in his chapter on prayer, and by the discussion of the author of al-Tira $\bar{z},{ }^{222}$ is that [seated prayer that includes prostration] does not remove the obligation to perform the pilgrimage, and that [a pilgrim who prays seated] need not repeat his prayers. ${ }^{223}$

After this al-Hatțāb wrote the following in [his] third note: ${ }^{224}$

[Concerning the case of] someone who knows about himself that if he travels by sea he will be afflicted by a sickness that will cause him to lose awareness or consciousness, and that he will thus abandon prayer altogether, there is no disagreement as to the impermissibility of his traveling by sea. For someone in this condition, his setting forth for the pilgrimage is nothing but a covetous desire, or rather [the result of] satanic incitement. Al-Burzulī stated: "Our master Muhammad al-Shabībīîn ${ }^{225}$ told us, based on [the report of] a Maghribī student,

220 This is the same al-Lakhmī (d. 478/1085-6) whose fatwās appear in Appendix A.

221 Ibrāhīm b. 'Alī b. Farḥūn (d. 799/1397), Medinese Mālikī jurist and author of the biographical dictionary al-Dībāj. Makhlūf, Shajarat al-nūr, 1:319-20.

This is most likely Tirāz al-Majālis (The Embroidery of the Councils), an unfinished commentary on the Mudawwana of Saḥnūn, by Sanad b. Inān b. Ibrāhīm, known as Qāḍī Sanad (d. 541/1146-7), an Egyptian Mālikī jurist and judge. Ibn Farḥūn, al-Dībāj, 208; Makhlūf, Shajarat al-nūr, 1:184.

223 These statements follow a long discussion of these jurists' and others' opinions on the cases of prayer in which prostration is performed "on his brother's back," either during Friday prayer (on land) or at sea, and also regarding prayer in which the qiyām, or standing component, is omitted because of fear or sickness, again either on land or sea (fear of drowning, sea-sickness). In this context, "praying seated" refers to this omission of qiyām, which is seen by some (in the first group here) as analogous to omitting prostration, but not by others (Qāḍi Sanad in particular), because the omission of qiyām is acceptable under a wider range of circumstances than is the omission or incorrect performance of prostration - the latter is accepted only in cases of necessity (darüra). Thus the sense here is that it is agreed that if the would-be pilgrim cannot prostrate, he should not go to sea and he is not obligated to perform the pilgrimage as a result of his inability. If, however, he cannot stand during prayer (but can prostrate), jurists disagree as to whether this same assessment applies, or whether he remains able and obligated to perform the pilgrimage, as well as excused from repeating those prayers that he performs seated. Al-Lakhmī appears in both camps because, according to al-Ḥatțāb, the implications of the statements he makes in his chapter on pilgrimage and those in his chapter on prayer contradict one another. Al-Ḥațțāb, Mawāhib al-Jalīl, 3:478-80.

This is the same al-Shabībi as mentioned in Appendix A. 
that it is said: "The demonic beings of the East and of the West argued over which of them is greater in leading [men] astray. The demonic beings of the East said: ${ }^{226}$ 'We are stronger, because we find a man who is with his family and children, and he is performing what is required in terms of prayer, almsgiving, and other duties, and he is at ease, and his angels are likewise [at ease] with him because of the paucity of misdeeds [to be recorded against him]. But when a poet's recitation inspires longing for the Hijāz, we urge him on. Then he cries, and we prompt him to set forth. Then from the day of his departure, we prompt him to abandon his required duties and to do that which is forbidden, until the day of his return to his family. Thus he suffers loss in his person, wealth and religion, in the eastern and western parts of the earth.' Thus the satanic beings of the West conceded to them this ability to lead [men] astray." Al-Burzuli stated, "I have witnessed some of this during my travel to the pilgrimage." We ask God for health and safety.

The Knower of God, my master Ibn 'Abbād227 - may God be pleased with him - in his al-Rasāil al-sughrā (Smaller Collection of Letters), after a valuable discussion, stated the following:

There are three types of pilgrimage journeys. [The first] is completely praiseworthy. It is the journey of one who is knowledgeable, certain, and free from personal desire and from the domination of natural inclinations, because his motivations for this are the requirements of religion and the light of certainty. This is an honorable state, a lofty, exalted position known only by those who have occupied it. [A story] has been told about one of the scholars, who said, "While I was circumambulating the House, an old man came up to me and asked me about my country. I told him about it, and he said to me, 'How far is it from there to this place?' I said to him, 'About two months' [journey].' He said to me, 'You could perform the pilgrimage to this House every year!' I said to him, 'And

226 From this point forward, al-Ṣiqilli’s version of this story departs considerably from the version in Mawähib al-Jalïl, in which it is the demonic beings of the West who lead pilgrims astray.

227 Abū 'Abd Allāh Muhammad b. Ibrāhīm b. 'Abbād al-Rundī al-Nafzī (d. 792/1390), a prominent Șūfì of the Shādhilī order and Mālikī jurist. He was born in Ronda, in present-day Spain, but lived most of his life in Morocco. $E I^{2}$, s.v. "Ibn 'Abbād" (Paul Nwiya); al-Kattānī, Salwat al-anfās, 2:149-59; Makhlūf, Shajarat al-nūr, 1:343-4. This collection of letters has been edited and translated into French by Paul Nwiya as Lettres de Direction Spirituelle (Beirut, 1958 and 1974); this work served as the basis for the English translation: John Renard, S.J., ed. and introd., Ibn 'Abbād of Ronda: Letters on the Șüfi Path (New York: Paulist Press, 1986). Letter 6, pages 112-39, deals with the pilgrimage at length. 
you, how far is it from your land to this place?' He said to me, 'A journey of five years. I left my country when I was a young man." He [the scholar] said, "I was amazed by this," and he began to recite:

Visit whom you love, even if the land be distant from you,

And separated by barriers and curtains.

Distance must not prevent you from visiting him,

For the lover is a frequent visitor to the one he loves.

It is also said that the master Abū al-Hasan al-Lakhmì was sitting one day with his associates, discussing the legal assessment of the pilgrimage in their time, and whether the obligation to perform it remained in effect or had fallen away. They spoke at great length, while behind them a poor man was listening to them. When they had finished with this [discussion], he inserted his head into the circle and said, addressing the shaykh:

Oh my Master,

If shedding my blood was your utmost desire,

Your vision would not extend beyond shedding my blood. ${ }^{228}$

[The second type of pilgrimage] is completely blameworthy. It is the journey of one whose qualities are the opposite [of the praiseworthy pilgrim]. His interest in [performing the pilgrimage] is mere ostentation and [an inflated] reputation, because his motivation for this [journey] comes only from the dominance of his passions over him. As for the journey that is partly praiseworthy and partly blameworthy, it is that of a person who is devout or possesses knowledge, this [favorable quality] remaining alongside his pleasures and cravings. He is ignorant of the Enemy's machinations and of the deceits of personal appetite in contributing to the motivating forces that encourage his journey, and [ignorant] of these forces' interdependence.

This is a slight abridgement. He has elaborated - may God be pleased with him - on this matter at great length following this, and [his discussion] should be studied. ${ }^{229}$

228 Renard interprets this passage as having nearly the opposite meaning, translating the passage as follows: "O my Master, If you had not the least desire to shed my blood, You would hardly give excessive consideration to it" (Renard, Ibn 'Abbād, 113). In a note Renard adds, "The rather enigmatic verse that ends the anecdote seems to mean something like, 'If you really have no intention of making Pilgrimage, and are worried only about the duty and not the devotional aspects of it, why talk about it so much?'" (214). Based on the longer passage that follows, taken from Mawāhib al-Jalïl, I have interpreted the passage as providing an alternate framework within which the pilgrimage could be permitted despite its questionable legality or validity in the strict view of the law. This "Șūĩ viewpoint" emphasizes that one who is piously devoted to performing the pilgrimage will do so regardless of the obstacles and with little concern for personal loss or injury. 
The story about al-Lakhmī that I mentioned is also recorded by al-Ḥațāb, related by his [viz., al-Lakhmī's] student al-Māzarī, stating: ${ }^{230}$

Al-Lakhmì thought well of this allusion [on the part of the poor man], from the viewpoint of the Șūfì path rather than from that of the law. Al-Tādilī related this. He wrote: Al-Sirāj recited:

They said: Beware of the local men; they have an eye on you. When you do not sleep, it has not slept.

I said: My blood is their utmost desire;

their vision has not extended beyond shedding my blood.

By God, if my soul learned of whom I love,

It would take first precedence, to speak nothing of the last.

Thus the result of what we have written and what has become evident from what we have established is that in the case of someone who fits the description mentioned in the question, either demonstrably or presumptively, his setting forth is not permitted, nor is enabling him [to do so] permissible by any means. [This is] according to all of the schools of law and is [reflected] in all of the opinions, due to the lack of 'ability' that is a condition [of the pilgrimage] by a clear text of the Qurān, and as a result of the religious and worldly corruptions that proceed from [this lack of ability], which require no proof. These include those that have been mentioned as well as others that have not been mentioned, for which there have been eye witnesses. Thus, it is incumbent upon the one who has been entrusted by God - blessed and exalted is $\mathrm{He}$ - with the affairs of those who worship Him, to establish for this a general rule, by which the agent of corruption will be removed, in order that the journey will be undertaken in a legitimate, legally compliant manner.

We ask Him - glorified and exalted is $\mathrm{He}$ - by His grace, which cannot be measured by tongues and pens, to set right the lands and worshippers and to include them in the glories of [divine] favor. ${ }^{231}$ [We also ask Him] to render victorious the limb of the monotheistic, prophetic, and praiseworthy tree and the branch of the garden of the Prophet, the Hāshimites, and 'Alawids, the excellence of which has pervaded Islam. For mankind in the shade of protection, the Provider has stretched out His branch from the tree of prophethood, which was planted in soil mixed with the water of divine inspiration and watered by the rain clouds of the Message, so that the musk of guidance, the ambergris of piety and the camphor of majesty emanated from it.

[This branch is] the defender of the community and the religion, the suppressor of transgressors, the benefit of the days and nights, the pupil of excellency's eye, the

230 Al-Ḥaț̣āâ, Mawāhib al-Jalīl, 3:456-7.

231 Al-Wazzānī omits these next two paragraphs. 
possessor of every good character trait and every agreeable disposition, the Commander of the Faithful, our lord al-Hasan. ${ }^{232} \mathrm{Oh}$ God, in honor of the one who prescribed the rituals, his [viz., al-Hasan's] ancestor the Messenger and Warner, aid our lord the Commander with your sustenance and support. Perpetuate his brilliant dynasty and his radiant, prosperous life. Let him reign over [all of] the regions of the earth and surround the lands of victory with his banners. Oh God, let triumph and consolidation be joined to his flag, and [territorial] integrity and clear conquest charge out before his companions and supporters. Let him live out the remainder of his life, Oh God, in obedience to you, and bestow upon him the greatest victory, ${ }^{233}$ an abiding vision of You. Bless him and his noble progeny with good fortune, and through your munificence, Oh God, protect them from the misfortunes of the days and nights, in honor of his ancestor, our master Muhammad - may the best blessings and purest peace be upon him. May you be preserved for eternity, you who are a refuge for his family. This is a comprehensive prayer for all of creation.

This is the [answer] that is feasible for the poor servant 'Abd al-Hādī al-Husaynī alȘiqillī, who acknowledges his inability and inadequacy, and attributes all knowledge to the Omniscient and Knowing - may God include him among the people of witness and revelation.

[The following is written in the left margin of the last page, in a different hand $]^{234}$

Praise be to Him. Hamīd b. Muḥammad Bannānī235 - may God grant him success through His grace - insignificant servant of his lord, who is captivated by his knowledge, is in agreement with what has been recorded and elucidated on these six pages. He requests of our Lord that he grant success to our master, al-Manșūr bi'llāhi ("Victorious with the Aid of God") in every endeavor aimed at the good of the world and the religion, and to fulfill his hopes for his progeny, in honor of the Prophet and his family - may God's purest blessings and peace be upon him, Amen.

232 Al-Ḥasan I b. Muḥammad Iv (r. 1290-1311/1873-1894) was a member of Morocco's 'Alawid (or Alouite) dynasty, still in power, that claims descent from Muḥammad through Fāṭima and 'Alī. Clifford Bosworth, The New Islamic Dynasties (New York: Columbia University, 1996) 53-54. In al-Șiqillī's metaphor, al-Hasan I represents the branch of the prophetic family that is stretched out to protect the people of the Maghrib.

233 The word here for victory, fath, has a dual meaning referring both to the military conquests of the preceding sentences and the (greater) mystical sense of "opening" or direct knowledge of God.

234 Al-Wazzānī omits this note.

235 I have been unable to locate this Bannānī in the biographical dictionaries. 